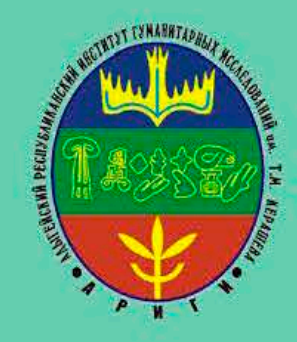
Адыгейский республиканский институт гуманитарных исследований имени T.M.Керашева

\title{
ЭТНОФИЛОСОФИЯ АДЫГОВ: ОТ МИФА К ЛОГОСУ
}

МАТЕРИАЛЫ КРУГЛОГО СТОЛА. ПОСВЯЩЁННОГО 75-ЛЕТИЮ ДОКТОРА ФИЛОСОФСКИХ НАУК, ПРОФЕССОРА ХАНАХУ РУСЛАНА АСХАДОВИЧА 
Адыгейский республиканский институт гуманитарных исследований имени Т.М.Керашева

\section{ЭТНОФИЛОСОФИЯ АДЫГОВ: ОТ МИФА К ЛОГОСУ}

Материаль круглого стола, посвящённого 75-летию доктора философских наук, профессора Ханаху Руслана Асхадовича (Майкоп, 24 мая 2016 г.) 
УДК 1/14 (=352.3) (082)

ББК. 87.3 (2 Рос. Ад 61)

$Э 91$

Публикуется по решению Ученого совета

Адыгейского республиканского института

гуманитарных исследований им. Т.М. Керашева

Составитель и научный редактор:

Делова Л. $\boldsymbol{A}$. - кандидат социологических наук.

Автор предисловия:

Тугов Р. Г. - кандидат философских наук

Рецензенты:

Нехай В.H. - доктор социологических наук;

Шаов $\boldsymbol{A} . \boldsymbol{A}$. - доктор философских наук.

Э 91 Этнофилософия адыгов: от мифа к логосу: Материалы Круглого стола, посвящённого 75-летию доктора философских наук, профессора Ханаху Руслана Асхадовича / под науч. ред. Л. А. Деловой [Электронный ресурс]: текстовое электрон. изд. - Майкоп: АРИГИ; ЭлИТ, 2016. Майкоп, 2016. - Электрон. дан. (2 Мб) -1 электрон. опт. диск (CD-R).

ISBN 978-5-9909192-0-4.

doi: 10.18411/elit-026

В книгу вошли материалы (научные доклады, статьи и выступления) Круглого стола «Этнофилософия адыгов: от мифа к логосу», проведённого 24 мая 2016 года в Адыгейском республиканском институте гуманитарных исследований, посвящённого 75-летнему юбилею известного российского и адыгского философа и социолога, доктора философских наук, профессора Ханаху Р. А.

Доступен в сети Интернет http://dx.doi.org/10.18411/elit-026.

УДК 1/14 (=352.3) (082)

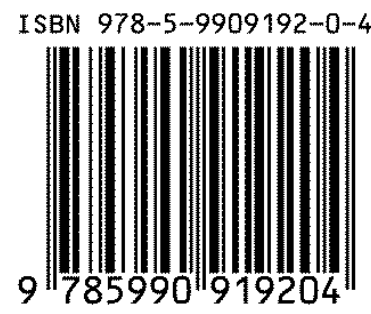

ББК. 2

(С) ГБУ РА "АРИГИ им.Т.М.Керашева", 2016

(C) Коллектив авторов, 2016

(C) Оформление электронного издания ООО "ЭлИТ", 2016 


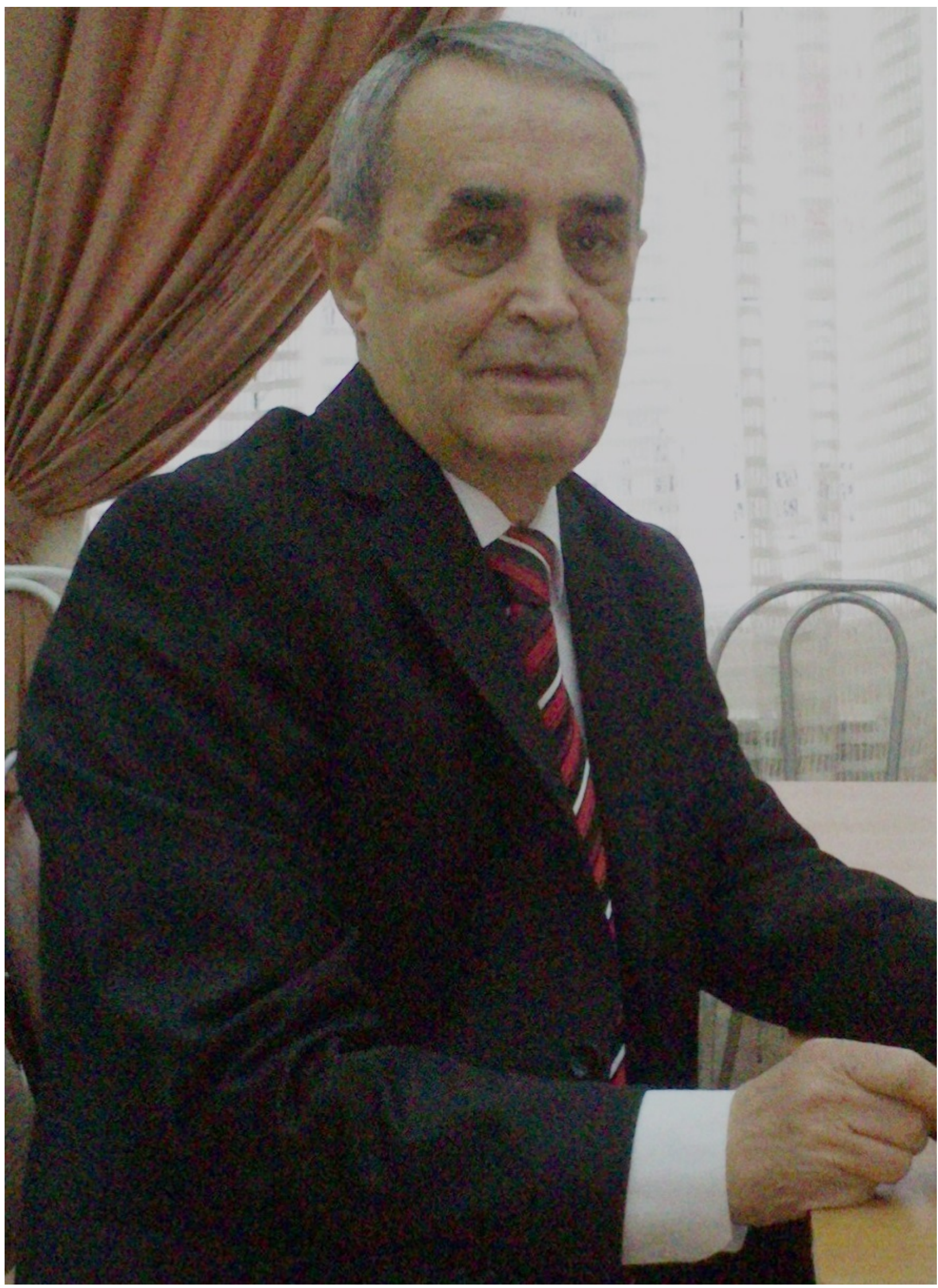

Доктор философских наук, профессор Ханаху Руслан Асхадович 


\section{ОГЛАВЛЕНИЕ}

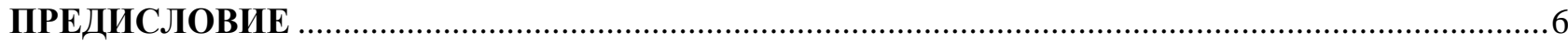

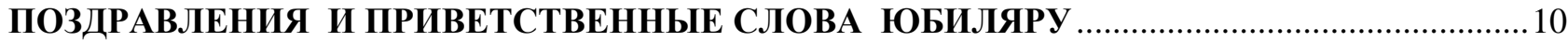

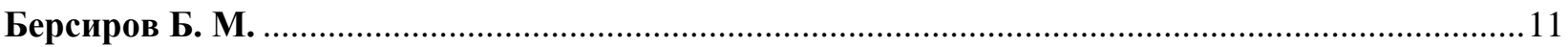

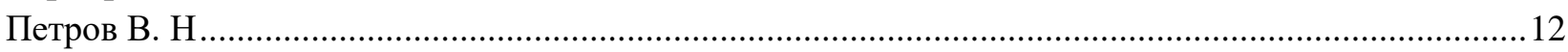

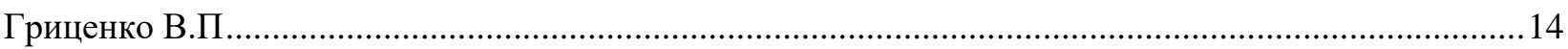

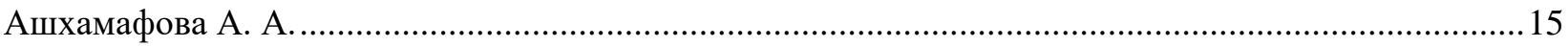

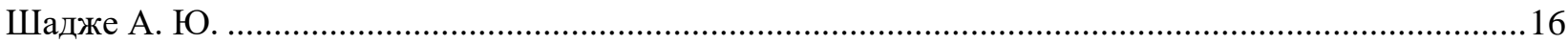

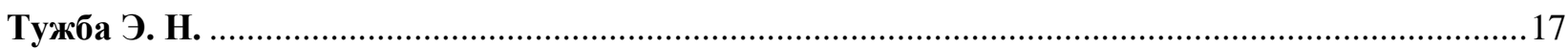

РАЗДЕЛ І. ЭТНОФИЛОСОФИЯ АДЫГОВ: ГЕНЕЗИС И СПЕЦИФИКА ...................................18

Жане 3. К. Эволюция идей Мурата Ягана: от устной традиции к логосу …….................................19

Губжоков М.Н. В поисках идеального государства: платоновские мотивы

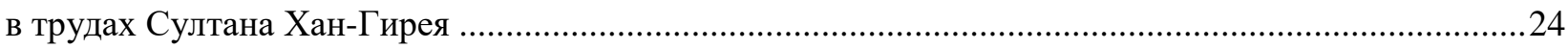

Паранук К. Н. Философский контекст прозы Нальбия Куека ........................................................38

Мамий Р.Г. Человек и его существование в творчестве Аскера Евтыха:

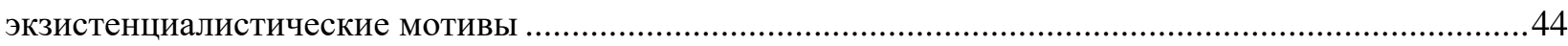

Хуако Ф.Н. Философская мотивация с учетом ее этноракурса в прозе адыгских авторов конца ХХ в.

Схаляхо Д. С. Этноментальные ориентиры художественных поисков в кросс-культурном

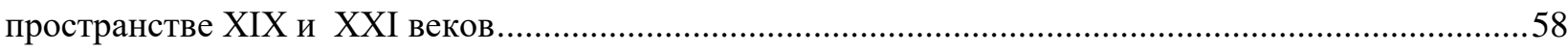

Цуекъо Н. М. Ц1ыф губзыгъэу Къэзанэкъо Джэбагъэ 1ор 1уатэм ч1ап1эу щиубытырэр.....................66

Тугов Р.Г. Специфика философско-гуманистического учения Тембота Керашева

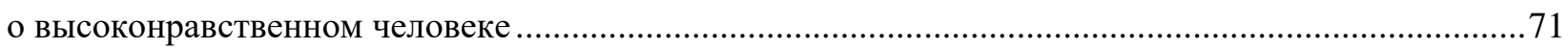

РАЗДЕЛ ІІ. НАТУРФИЛОСОФИЯ АДЫГОВ: ЧЕЛОВЕК И ПРИРОДА .................................... 79

Тхагапсова Г.Г. Натурфилософские взгляды в народной медицине адыгов ......................................80

Ачмиз К.Г. Математические элементы в адыгской мифоэпической традиции ..................................8 88

РАЗДЕЛ ІІІ. КУЛЬТУРФИЛОСОФИЯ АДЫГОВ: ЧЕЛОВЕК И КУЛЬТУРА ..........................99

Шадже А. Ю. Адыгея в современном культурно-идентификационном пространстве России .........100

Калашаова Д.А. Социоэтнокультурный феномен традиционной свадебной обрядности адыгов ...116

Нехай В. Н., Шаов А. А. Этносоциальные процессы на Юге России

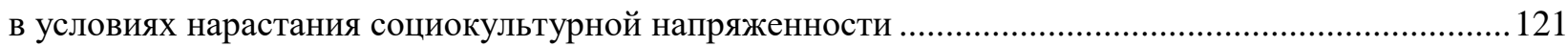

Жаде 3.А., Хуако 3.Ю. Этнос и социокультурная среда функционирования языка .........................129

Куек А. С. Философия единоборства в историко - фольклорной парадигме этноса ..........................138

Мусхаджиев С.-Х. Х. Историческое сознание в социокультурном пространстве .............................159

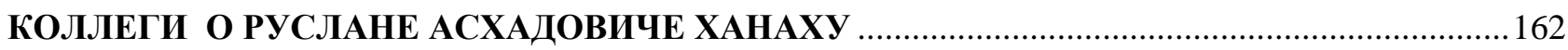

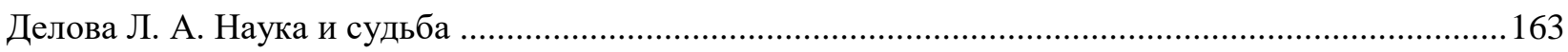

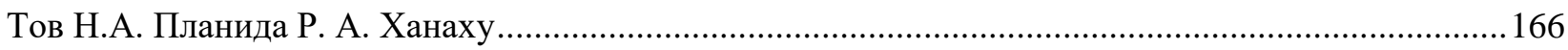

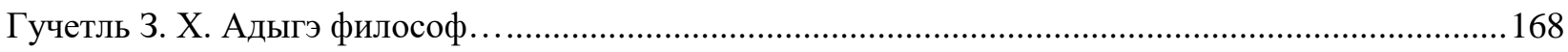

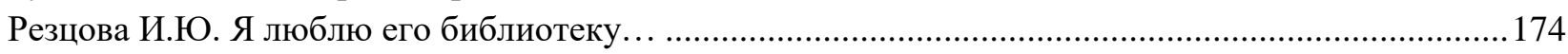

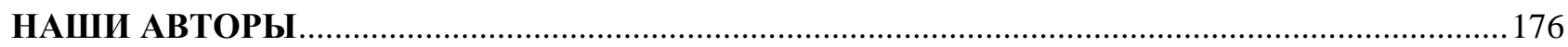




\section{ПРЕДИСЛОВИЕ}

В книгу вошли материалы (научные доклады, статьи и выступления) Круглого стола «Этнофилософия адыгов: от мифа к логосу», проведённого 24 мая 2016 года в Адыгейском республиканском институте гуманитарных исследований имени Т. М. Керашева, посвящённого 75-летнему юбилею известного российского и адыгского философа и социолога, доктора философских наук профессора Ханаху Р. А.

Структура книги определяется логикой последовательного выступления участников и гостей, решения основных задач Круглого стола по проблеме возникновения и развития этнофилософии в истории адыгской культуры и литературы. Книга включает в себя: предисловие, поздравления и приветственные слова Юбиляру и участникам Круглого стола от гостей и коллег; три раздела, состоящие из научных докладов и статей на русском и адыгском языках; заключение.

В первый раздел книги «ЭТНОФИЛОСОФИЯ АДЫГОВ: ГЕНЕЗИС И СПЕЦИФИКА» вошли научные статьи современных историков, философов и филологов: Жане 3. К., Губжокова М.Н., Тугова Р.Г., Паранук К. Н., Мамий Р. Г., Хуако Ф.Н., Схаляхо Д. С., Чуяковой Н.М. (Цуекъо Н.). В их научных работах исследуются различные подходы к пониманию этнической философии адыгов, позволяющие выявить этноментальные философские и художественные ориентиры и поиски в адыгском культурном пространстве XIX, XX и XXI веков.

В статье З.К. Жане «Эволюция идей Мурата Ягана: от устной традиции к логосу» анализируются три компонента философского успеха турецкого, канадского и абхазского философа Мурата Ягана: аутентичность, идентичность и элективность. Это то, что называется, - искусство жить. «Сделай свою жизнь произведением искусства», - говорит Мурат Яган. И сделал!

Губжоков М. Н. в работе «В поисках идеального государства: платоновские мотивы в трудах Султана Хан-Гирея» рассматривает философские представления об общественном благе, долге и о справедливости правителя. Подобно античному философу-идеалисту Платону, Султан Хан - Гирей свою жизнь потратил на поиск путей преобразования адыгского общества, стремясь к идеальному мироустройству, подчиненному законам справедливости.

Паранук К. Н. в исследовании «Философский контекст прозы Нальбия Куека» рассматривает философскую основу этики адыгского писателя и определяет концептуальную философскую идею его определенных произведений (повесть «Черная гора», роман «Вино мертвых»). В них выявляются герои с трансцендентным сознанием, наделенные бессмертием и пребывающие на грани реального и ирреального миров. 
Мамий Р. Г. в своем философско-литературном анализе «Человек и его существование в творчестве Аскера Евтыха» выявляет экзистенциальные мотивы в творчестве Аскера Евтыха. Они, по мнению исследователя, были заметны в первых произведениях А. Евтыха, особенно в книгах «Мой старший брат», «История одной женщины», «След человека». Экзистенциализм ярко был показан писателем на примере характера героини Щащи из повести «История одной женщины». Этот трудно понимаемый (экзистенциональный) процесс полностью проявлялся в ее жизни, в ее отношениях к мужу Асланбию Хатажукову.

Хуако Ф. Н. в статье «Философская мотивация с учетом ее этноракурса в прозе адыгских авторов конца XX в.» проследила логически обусловленные мотивации, имеющиеся в текстах современных адыгских писателей. Рассматривая произведения Н. Куека, Ю. Чуяко и С. Панеша с точки зрения экзистенциализма, Хуако Ф.Н. обращается к прослеживанию экзистенциональных ситуаций в обозначенном материале с выведением конкретной технологии философизации прозы.

Схаляхо Д. С. в научной работе «Этноментальные ориентиры художественных поисков в кросс-культурном пространстве XIX и XXI веков» прослеживает, как в разные исторические эпохи Лермонтов М.Ю. и Чуяко Ю.Г. осмысливают в своих произведениях тему мужества и бесчестия. Д. Схаляхо выявляет историко-культурные истоки художественных образов поэмы Лермонтова М.Ю. «Беглец» и повести Чуяко Ю.Г. «Последний лай старого выжлеца». Индивидуализм героев трактуется ими в морально-философском аспекте, предусматривающем: славная кончина лучше, чем позорное спасение. Основной вывод, вытекающий из сопоставительного анализа поэмы Лермонтова М.Ю. и повести Чуяко Ю.Г., состоит в том, что этническая ментальность не исчезает, но она видоизменяется в разные исторические периоды.

Чуякова Н.М. (Цуекъо Н.) посвятила свою статью на родном языке адыгскому мудрецу, дипломату и общественному деятелю Жабаги Казаноко (Джэбагъэ Къэзанэкъо), чей авторитет непререкаем вот уже несколько веков. Анализируются философские изречения мудреца, отражающие этическую систему его мышления. Более того, Нафисет Чуяко дополнила образ народного мыслителя Жабаги Казаноко и сделала попытку определить его роль и место в истории культуры адыгов.

Тугов Р. Г. в своем философско-гуманистическом исследовании «Специфика философско-гуманистического учения Тембота Керашева о высоконравственном человеке» выявляет «идею гуманистического антропоцентризма» как основное понятие в мировоззрении и творчестве Тембота Керашева. Главная особенность философско-гуманистического учения Т. Керашева заключается в том, что в нем отсутствует современная тенденция отождествления, взаимного подчинения или взаимного противопоставления морально - этических понятий адыгской философии и этики: «человечность (цІыфыгъэ)», «адыгственность», «адыгагъэ». Их можно и нужно 
соединять, но нельзя их отождествлять. Их можно и нужно разделять, но нельзя их противопоставлять друг другу.

Во вТорой раздел книги «НАТУРФИЛОСОФИЯ АДЫГОВ: ЧЕЛОВЕК И ПРИРОДА» вошли научные статьи современных историков и натурфилософов: Ачмиза К.Г., Тхагапсовой Г. Г. В их натурфилософских исследованиях анализируются естественно - научные взгляды адыгов, позволяющие выявить практические знания в области как точных, так естественных наук.

Ачмиз К.Г. в оригинальной работе «Математические элементы в адыгской мифоэпической традиции» впервые анализирует математические элементы (система счисления) в адыгском героическом эпосе. Автор утверждает, что наличие системы счисления у адыгского народа - это первый шаг к возникновению письменности. Далее он прослеживает, откуда в эпосе знания? Обнаруживается такая линия: мудрец (знания у него из природы) - бог (узурпатор знаний) - человек, делающий орудие для другого человека. Это как бы схема трансляции знаний, а коммуникация идет от человека к человеку. Мы видим, что человек одновременно совмещает в себе и ум мудреца, и физическую мощь бога. Таким образом, адыгский эпос весь пронизан верой в разум человека, в его умственные возможности.

Тхагапсова Г.Г. в своей работе «Натурфилософские взгляды в народной медицине адыгов» провела параллели между подходами к врачеванию в народной медицине адыгов (преемников меотской культуры) и древнегреческой медицины, описанные в Гиппократовом сборнике.

Таким образом, Тхагапсова Г.Г. находит общие подходы в понимании болезни и принципах их лечения как в развитой древнегреческой медицине, так и древнеадыгской народной медицине.

В третий раздел книги «КУЛЬТУРФИЛОСОФИЯ АДЫГОВ: ЧЕЛОВЕК И КУЛЬТУРА» вошли научные статьи современных историков, социологов и социальных философов: Шадже А. Ю., Калашаовой Д.А., Куек А. С., Нехай В. Н., Шаова А. А., Жаде 3.А., Хуако 3.Ю., Мусхаджиева С.- Х. Х. В их исторических и социально-философских работах раскрываются социоэтнокультурные явления в древней и современной адыгской истории и культуре. Анализируется специфика философского понимания человека в условиях современного социокультурного пространства и среды.

Шадже А. Ю. в своем очень интересном социально-философском исследовании «Адыгея в современном культурно-идентификационном пространстве России» рассматривает культурную идентичность человека в контексте современной, постнеклассической науки. Целью ее исследования является не только определение идентификационных особенностей Адыгеи в современном социокультурном пространстве России, но также и осмысление тезиса о необходимости укрепления российской национальной идентичности. Что касается адыгского этноса, то свое существование и дальнейшее развитие, по убеждению А. Шадже, он связывает только 
с Россией, только в составе российской гражданской нации, только в социокультурном пространстве России.

Калашаова Д. А. в исследовании «Социоэтнокультурный феномен традиционной свадебной обрядности адыгов» выявила специфику свадебной обрядности адыгов, определяемой этническими особенностями адыгского этноса. Она обращает внимание на свадьбу как своеобразное творчество народа.

Нехай В. Н. и Шаов А. А. в социально-философской работе «Этносоциальные процессы на Юге России в условиях нарастания социокультурной напряженности» рассматривают и выявляют специфику этносоциальных процессов в поликультурном пространстве Юга России. Авторы отмечает, что глобализация в своей унификационной вариации порождает новые вызовы цивилизационной уникальности Северного Кавказа. Подобная уникальность создает рискогенную социокультурную среду для сохранения этнокультурной идентичности народов рассматриваемого региона.

Жаде 3. А и Хуако 3. Ю. в совместной работе «Этнос и социокультурная среда: функционирование языка» проанализировали актуальные проблемы создания и совершенствования алфавитов и письменностей. Выявили исторические и социокультурные аспекты выбора графики письма, а также условия и возможности функционирования языка того или иного этноса в социуме, в единой социальнокультурной и культурно-информационной среде.

Куек А. С. в статье «Философия единоборства в историко - фольклорной парадигме этноса» анализирует систему физического воспитания у адыгов, привлекая материалы эпоса «Нарты».

Мусхаджиев С.-Х. Х. в работе «Историческое сознание в социокультурном пространстве» рассматривает историческое сознание и историческую память адыгов в контексте истории Северного Кавказа. Историческое сознание - это очень сложное многогранное явление, которое включает в себя идеи, традиции, концепции, посредством которых индивиды и этносы формируют своё восприятие прошлых событий и выдающихся личностей. Историческое сознание имеет свои уровни. Первый, низший уровень, - это те впечатления, индивидуальные переживания, которые личность испытывает в своей повседневной жизни. Второй уровень исторического сознания - это историческая память. И философско-историческое осмысление этнической культуры связывает триедино прошлое, настоящее и будущее, тем самым обеспечивая связь времён и поколений.

Тугов Р. Г., кандидат философских наук 


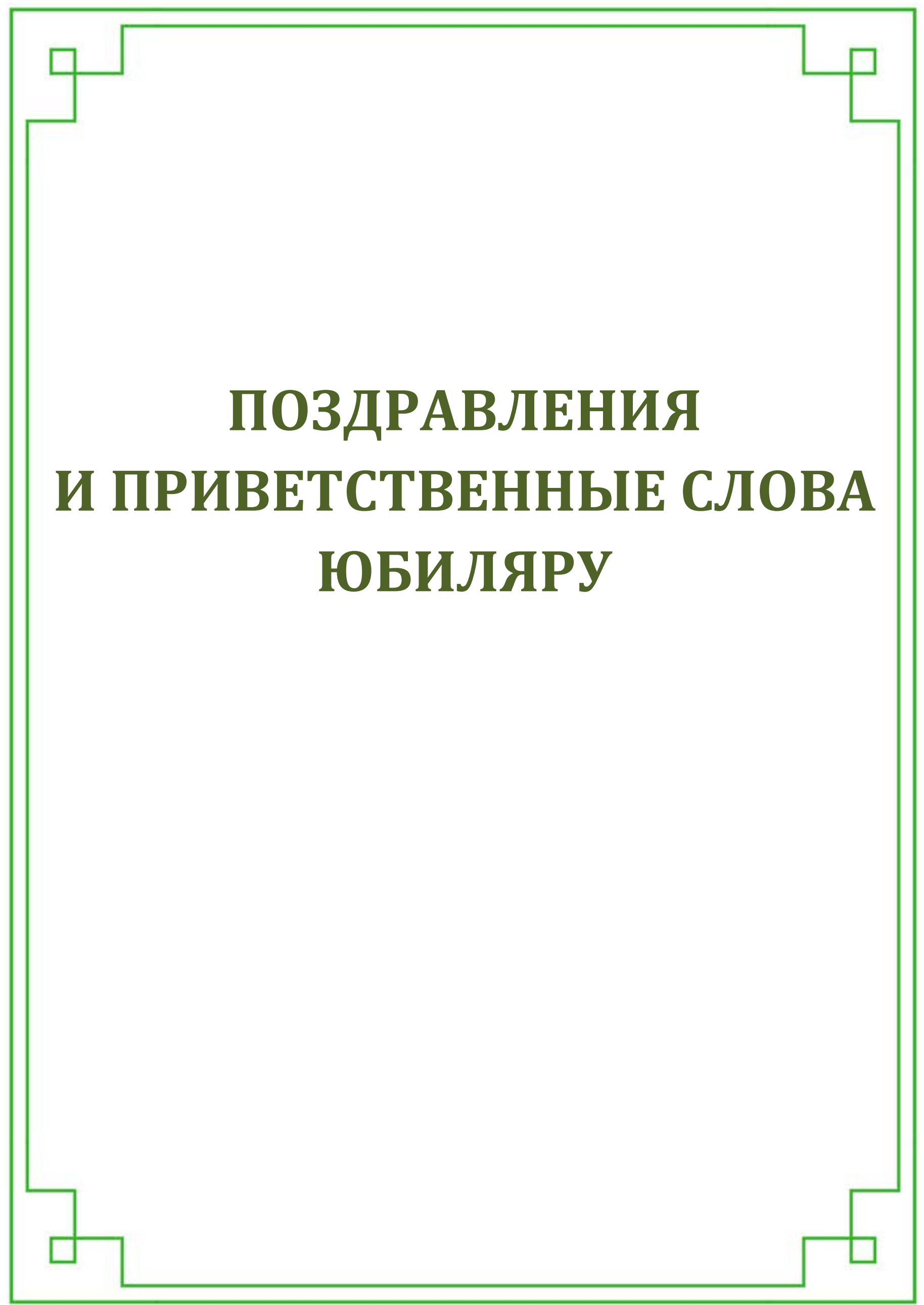


доктор филологических наук, профрессор,

директор Адыгейского республиканского института гуманитарных исследований имени Т. М. Керамева
Ученые Адъггейского республиканского института гуманитарных исследований им. Т. М. Керашева от всей души поздравляют Вас со знаменательньм днем - 75-летним юбилеем. Научная общественность не только Северного Кавказа, но и всего постсоветского пространства знает Вас как видного философа, соииолога, культуролога, организатора науки и общественного деятеля.

Руслан Асхадович, Ваши исследования, посвященные исследованию традииионной культуры, проблем адыгской этнофилософии, френомену "адыгагъэ", исторической памяти адыгов, получили широкую известность и высоко оиенены спеииалистами в нашей стране и за рубежом. Ученые нашего института высоко иенят Ваши усилия, направленные на изучение и популяризаиию духовных иенностей адъгов. Много сил и энергии Вы отдаёте делу подготовки спеииалистов высокой квалификаиии в диссертаиионном совете по соииологии в Адыгейском государственном университете.

Ваш талант ученого и организатора науки наиболее ярко раскрылся в ходе работы в качестве руководителя созданного Вами отдела фрилософии и соииологии Адыгейского республиканского института гуманитарных исследовании имени Т.М. Керашева. Вами создана и успешно функиионирует научная школа, где подготовлено много высококвалифииированных спеииалистов - кандидатов и докторов философских и соииологических наук. При Вашем активном участии в нашей республике и в других регионах страны подготовлено иелое поколение научных кадров.

Руслан Асхадович! Мы искренне желаем Вам крепкого здоровья, счастья, благополучия, успехов в научной и просветительской деятельности. Пусть годы упорного труда и духовных исканий принесут Вам глубокое внутреннее удовлетворение. 
доктор сочиологических наук, nрофессор,

заведуюший кафедрой

сочииологии

Кубанского государственного университета
С огромнъим удовольствием принял приглашение Руслана Асхадовича принять участие в научнообиественном событии, которое связано с его юбилеем. С огромным удовольствием приезжаю в уютный Майкоп, которьй отличается радушностью, с которой здесь встречают гостей. Я себя здесь, на научных мероприятиях, уже чувствую не как гость, а как житель вашего гостеприимного города $u$ получаю от этого огромное удовольствие.

Мь все понимаем, что культура - это душа народа, и она имеет многослойный характер. Большое, ключевое значение принадлежит менталитету народа. Адъгский менталитет наиболее ярко и последовательно выражен в нартском эпосе. Подвиг героев нартского эпоса это не физическая сила, это сила ума.

Посредством этой силь удаётся одерживать верх и выходить из самых сложных и самых, казалось бы, невероятных ситуаиий. И вот эта сила ума очень хорошо просматривается, когда мы видим, насколько в Адъгее развито воспроизводство культурь, наука во всех её составляюиих.

Я могу говорить о соииологии, ибо именно по этой линии имею наиболее часто контакты в диссертаиионном совете с Русланом Асхадовичем. Мь работаем в одном проекте, связанном с мониторингом межэтнических и межконфессиональных отношений в регионах Краснодарского края, Республики Адъгея $u$ Волгоградской области. Это проект, которыми руководит академик Тишков, проходит как госзаказ Министерства образования и науки. такое сотрудничество носит весьма продуктивный, плодотворный характер. Мы опираемся на его компетентность и высокосодержательную научность. Руслан Асхадович участвует в нашем проекте.

Он стал одним из первых, кто в соииологическом ключе исследовал трагедию, соииальнополитические последствия Кавказской войны применительно $к$ состоянию современного обиественного сознания в Республике Адъгея и Краснодарском крае. Его публикаиия в журнале "Соииологические исследования" Института 
Петров В. Н.,

доктор социиологических наук,

nрофессор,

заведуюший кафедрой

сочииологии

Кубанского государственного университета соииологии РАН в своё время открыла эту тему и открыла многим глаза на то, как воспринимаются обиественным сознанием в Адыгее и Кубани последствия Кавказской войны. И исследование продолжается, оно носит уже мониторинговый характер. Я, может бъть, даже своеобразно завидую, ито в Адъгее есть такой институт гуманитарных исследований, где работают такие серьёзные учёные.

Заключая своё выступление, хотел бы сказать, что в соииологии часто сталкиваются парадигмы - объективизма и субъективизма. Суть заключается в том, что рассматривая реальность, мы иной раз думаем, ито что-то уже есть, u находимся во власти экономической ситуаиии, политических проиессов, правового поля, то есть всего того, что уже институализировано $и$ с чем обречены соглашаться.

Но, с другой стороны, есть человеческая субъективная активность с её потребностями, мотивами, интересами, установками, ито двикет человеком, благодаря чему мы движемся вперёд.

Культура - очень тонкое, хрупкое явление, и во многом мы можем сожалеть по поводу того, ито многое утрачено под влиянием проиессов модернизаиии, глобализаиии. Но в то же время в наших силах позитивно влиять на многие явления u проиессы. $B$ этом контексте в республике немало делается именно благодаря институту гуманитарных исследований. И не просто по воспроизводству культуры, а по её обогашению всем тем, что добъто из недр этой культуры, и тем самьи составляет сегодня нашу актуальную действительность. 
доктор филологических наук,

nрофессор,

проректор Краснодарского университета культуры
Мне хотелось бы сказать о нашем сотрудничестве с Русланом Асхадовичем, которое длится не менее пятнадиати-двадиати лет.

Северный Кавказ - это место пассионариев. Кавказ - это истоки мировой культуры, связанной с мифрами, с Прометеем, это современная культура. По кавказской, точнее по адъгской культуре в контексте глобализаиии Руслан Асхадович выступил на мировом философском конгрессе в туриии. В кулуарах конгресса мы встречались и обиались со многими корифеями философской мыссли, в том числе с классиком европейской философии Ю. Хабермасом. И когда он узнал, ито Руслан Асхадович черкес, он бросился его обнимать.

Я хорошо помню презентаиию книги "Мир культуры адъгов: $\kappa$ проблеме эволюиии $u$ иелостности" в 2002 году в Aнапе. Очень тепло бъла воспринята презентаиия. Я ставлю эту книгу в один ряд с трудами фрраниузской школь Анналов, которые в 80 - 90-е годы стали широко появляться. Адыгский этнос несёт в себе многие иенности мировой иивилизаиии, которые ешё не полностью оиенены ЮНЕСКО и другими международньми организаииями. Надо, чтобы это произошио.

Институт гуманитарных исследований вносит огромный вклад в то, чтобы многие иенности адъгской культурь бъли признаны ЮНЕСКО достоянием мировой культуры. Это прежде всего адыгский этикет и героический нартский эпос.

Руслана Асхадовича я рассматриваю как патрииия духа, одного из лучиих носителей адъгского этикета, который всегда безупречно выдержан, взвешен в своих словах, решениях, какие бы проблемы он ни рассматривал, например, проблемы Кавказской войны или другие нравственные проблемь, как будто он отвечает за эти слова перед вечностью. Руслана Асхадовича, безусловно, можно рассматривать как рыцаря духа.

Я хочу вручить благодарность от имени Краснодарского регионального отоеления Российского философркого обиества за большой личный вклад в развитие отечественной философрии $и$ за развитие межкультурного диалога.

Хотелось бы сотрудничать с Вами. 
Ашхамафова A. A.,

доктор философских наук,

профессор кафедрь истории и

политологии Кубанского

государственного аграрного

университета

\section{Уважжаемые гости!}

Сегодня такой радостный праздник: нашему уважаемому Руслану Асхадовичу, моему любимому научному руководителю, любимому наставнику исполняется 75 лет. Мь сотрудничаем вместе довольно давно, Наши интересь сходились во многих областях научного знания: фрилософрии, соииологии, в философрскокультурологическом осмыслении адыгского героического эпоса "Нартхэр".

Я хочу сказать, ито культурно-исторический пласт нартского эпоса в Краснодаре не умирает. Я работаю уже около сорока лет в Кубанском аграрном университете, $и$ мы всегда проводим мероприятия, посвяшённые культуре, традиииям, объчаям адъгов. Культура адъгов, нартский эпос интересуют всех.

Я покажу вал несколько фотографий, итобы вы убедились, насколько востребована эта тема, насколько она актуальна, интересна, и как легко заинтересовать нартским эпосом людей различных наииональностей, различных народов.

Вы, наверное, знаете, что сейчас возврашается тендениия приглашать на учёбу к нам студентов из других республик. В нашем университете в этом году приехали студенты не только из бывших республик Советского Союза, но из Африки, Азии - со всех континентов. И на своих занятиях я их всех знакомлю с нартским эпосом наследием адыгов. С огромным интересом $и$ желанием воспринимают студенты со всех континентов наследие адъгов - великий нартский эпос, собиранию которого всю свою творческую жизнь, а это более 60 лет, посвятил мой отеи, Аскер Магамудович Гадагатль. 
Шадже А. Ю.,

доктор философских наук, nрофессор,

руководитель Адьгейского регионального отделения философского общества России
Уважсаемыегости,

уважсаемыеучастники юбилейной конференции! Дорогой наш Руслан Асхадович!

Позвольте мне от имени Адъгейского отделения Российского философрского обиества поздравить Руслана Асхадовича Ханаху. Смомента зарождения регионального отделения Российского фрилософского обиества Руслан Асхадович является бессменным членом нашего обиества. Его знают в Москве, мы с ним неоднократно принимали участие в работе российских фрилософоских конгрессов, в работе Межкоународного конгресса в Cталбуле.

Когда я обрашаюсь $к$ работам Руслана Асхадовича, я осмъисливаю, пьтаюос понять объект его исследования культура как сложная саморазвиваюииаяся система, $u$, в частности, традииионная культура. Что касается бъттия традииионой культурьы, он феноменально раскрывает этот аспект. Это оченъ глубокий анализ.

Он прибегает к авторской операиионализаиии понятий. Научный вклад в развитие региональной фрилософрской науки, конеино, неоспорим. А ито касается гносеологических аспектов, мы прекрасно знаем, что, не познав, нельзя понять.

Руслан Асхадович памогает нам с памошъю своих работ познать этническую культуру как слокное образование, как сложную открытую систему. Он не только изнутри смотрит на этот обьект исследования, со стороны адъгов (черкесов), проживаюиих в разньх странах, и соотносит оиенки извне со своими оиенками, ито даёт богатъй гносеологический опът.

Руслан Асхадович впервые дал экспликаиию понятия "adъlгство", что maкое адъгство, в чём суиность адыгства:. Наше представление, руководствуясь описательным методом, до его открытия превалировало в наших исследованиях. Но когда Руслан Асхадович со своим авторским оригинальным подходом выявил суиность адъгства, то, конечно, изменился взлляд не только на адъгетво, но и на этническую культуру в иелам. И перед нами открывается иной мир адыгской культуры.

Руслан Асхадович, хочу завершить свое вьступление самыми добрыми покеланиями. Я имею поручение от имени Российского фрилософрского обиества. Творческих Вам успехов, здоровья, чтоб Вы нас, читателей, коллег, радовали бесконечно своими интересньми изданиями. И рады сотрудничеству с Вами.

* Ханаху Р.А., Цветков О.М. Феномен адыгагъэ: к постановке иоследовательской проблемь//Фитософия и соииалогия в Республике Адъıея. 1994. Майкоп. 1994. С.6. 
Тужба Э. Н.,

доктор сочиологических наук,

профессор кафедры

социиологии, правоведения и

работыл с персоналом

Кубанского государственного

технологического

университета
Оиень приятно присутствовать здесь и поздравить Руслана Асхадовича Ханаху сего юбилеем.

Первый раз мы встретились в 2003году в Анапе, где проходила конферениия, организованная Краснодарским государственным институтом культуры и искусств. Понню очень впечатляюшую презентаиию коллективной монографрии «Мир культуры адьгов (проблемы эволюиии и иелостности)". На конфрерении я познакапился с двумя именитьими докторами философрсках наук, М. Н. Афрасижевьим и Р. А. Ханаху. Какя бъил горд, когда мне бьло доверено отвезти в Краснодар трех знаменитькх адьвов: А.А. Хагурова, М.Н. Афрасижева и Р.А. Ханаху.

В 2011 году я подготовил монографрию "Абхазия в глобализируюшем мире: соииалогиеский анализ", и наступил мамент, когда накоплен ограмный массив материала, но ты не знаешь, как дальше двигаться по этаму пути. Необходимо структурировать и выровнять собранный науиньй материал. Срочно нужнна была помошь глубокого спешиалиста по Кавказу. И когда я позвонил в Адьгею двум очень увакаемьим людям, они в один голос, не сговариваясь, сказали: "Иди к Руслану Асхадовичу Ханаху". После этого мы встретились, я оставил ему свой научный труд, а Руслан Асхадович пообешал ознакапиться с ним в течение двух недель. Когда мь снова встретились, буквальноза 20 минут, оноткрьллмне новое видение изучаемой проблемы, после чего работа очень замечательно поила. Но вначале он меня слегка пожурил. Я не сразу его понял, когда он сказал: "Такая огромная книга в 660 странии, ито за гигантизм. Сейчас ни у кого нет сил и времени такие большие обьёны читать. Тогда мне казалось-чем бальие, тем лучие. Сейчас, по прошествии многих лет, я понимаю, наскалько он бъл прав.

Я знаю, что Руслан Асхадович долго работал над культурноэтическим феноменом адьгагъэ, $я$-над феноменам апсуара. И я часто обрашался к работам Руслана Асхадовича, особенно к его работе "Традиионная культура Северного Кавказа: вызовь времени (соииально-философрскй анализ)". Меня поразило, с какой скрупулезностью он исследовал морально-этические нориы этноса, как он тиательно анализировал "бинарность", "релятивносты" поведения молодежи в рамках собственного соииокультурного круга (семья, деревня, аул) и их поведение за пределами этого круга в там же Краснодаре. При таких ситуаииях явно проспатривается то, как глобальные универсальные иенности соприкасаются, а иногда и "сталкиваются" с традииионной культурой. В любал случае еше доминируют именно традицинные иенности адьгов, которые сохранал народ.

Я от души поздравляю Руслана Асхадовича $c$ его замечательным праздникам. Он навсегда останется у меня в памяти как человек, который очень много для меня сделал. И ешёхотел бы обратить внимание на его науиньй стиль-у него классический стиль, которьй может слукить примероп многим молодьми исследователям. 


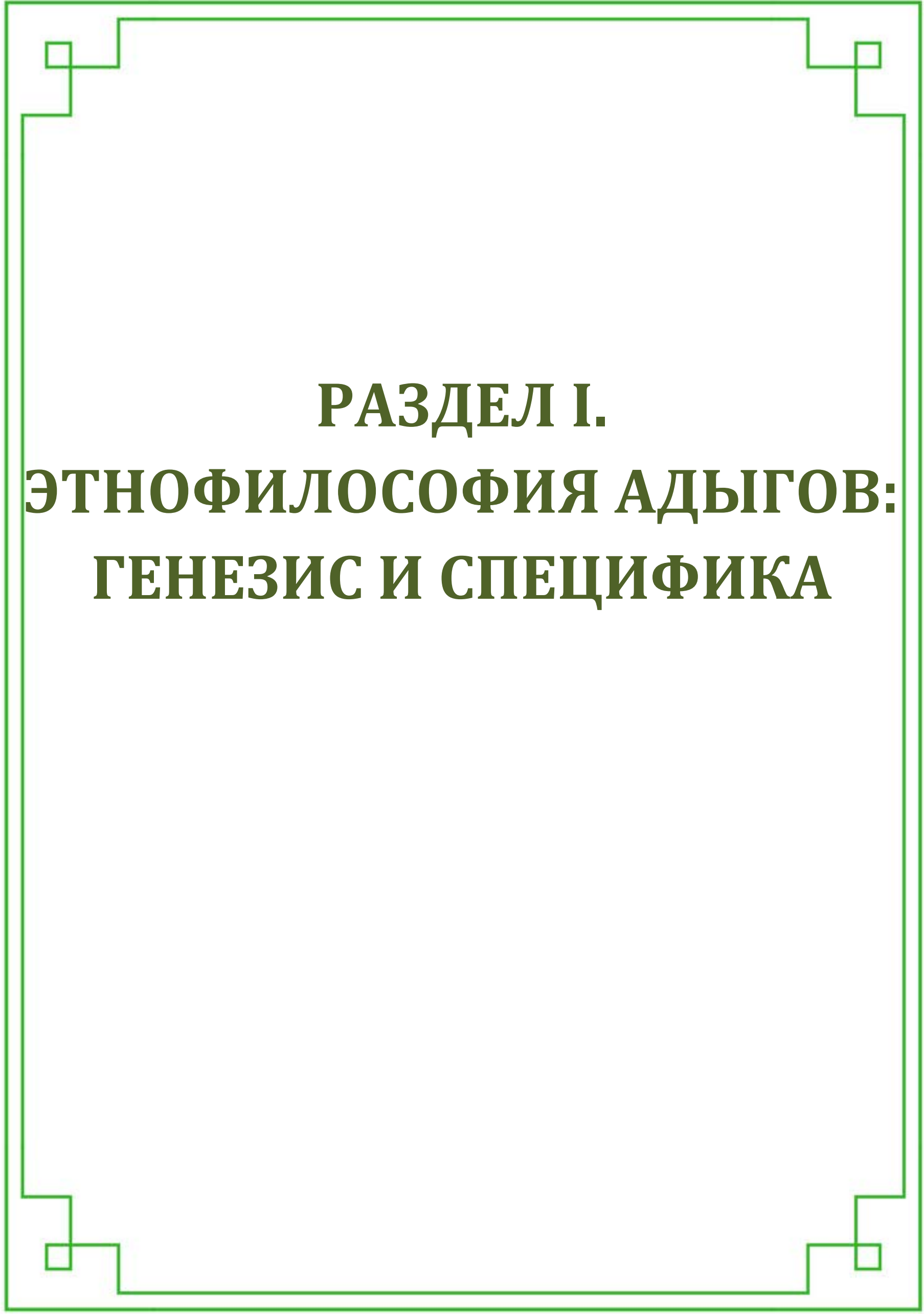


Жане 3. к.

\title{
Эволюция идей Мурата Ягана: от устной традиции к логосу
}

\begin{abstract}
Аннотация: В статье показано духовное развитие Мурата Ягана, философа абхазоабазинского происхождения. Эволющия идей Мурата Ягана от устной традиции к печатному слову, ее нарастающее распространение на Западе обеспечены подлинностью Хабзэ как иелостного духовного учения, его способностью менять свои формыл, сохраняя духовную суть; способностью органично существовать и развиваться в условиях мультикультурализма, противодействуя плавильному котлу этнического единообразия.

Ключевые слова: Кавказ, Канада, черкесы, этос, Хабзэ, мультикультурализм, миграчия, духовность, суфизм.
\end{abstract}

\section{К биографии мудреца}

Мурат Яган родился в абхазо-абазинской семье знатного происхождения в области Ачхара Северного Кавказа в 1915, затем иммигрировал в Турцию с родителями. Его детство проходит в Стамбуле в атмосфере становления режима Кемаля Ататюрка и его националистической идеологии. Дед Мурата был одним из видных руководителей черкесских общин в Турции. После провозглашения Турецкой Республики в 1923 отец Мурата работает в парламенте Турции, однако подает в отставку в 1926 в знак протеста против официальной компании, направленной на ассимиляцию национальных меньшинств, включая черкесов. Мать Мурата была турчанкой, из аристократической исламской семьи. В своих интервью Мурат описывает ее как набожную мусульманку. Яган рос в традиционной среде, в окружении родственников и знакомых, которые принадлежали к различным культурным направлениям. Его семья сумела обеспечить ему как традиционное воспитание в духе адыгагъэ и апсуара, так и современное западное образование.

Поиск духовной субстанции

Будучи разочарован ортодоксальным исламом, Мурат Яган начинает свой духовный поиск, еще будучи студентом-медиком. По настоянию своей матери он знакомится с суфизмом, в частности, с орденом Бекташи. Именно от суфиев он впервые слышит о влиянии Хабзэ на суфизм. По ряду причин в возрасте 40 лет Мурат вместе со своей семьей иммигрирует в Канаду. Пытаясь адаптироваться в западном обществе, он активно посещает христианские церковные институты и обнаруживает, что они “находятся в полном несогласии друг с другом”. В этот период он начинает участвовать 
в деятельности суфийских общин Канады и США. Интерес к суфизму в Северной Америке был в то время еще в зачаточном состоянии, и суфийские мастера часто приезжали из Турции, посещая своих учеников и последователей. Часто Мурат Яган выступает здесь переводчиком духовных бесед, в ходе которых близко познакомится с шейхом Сулейманом Деде - главой ордена Мевлеви, который был согласен с заявлениями Мурата о необходимости “очищения суфизма от шелухи исламской ортодоксии". В 1978 г. С.Деде предлагает Мурату Ягану возглавить канадский суфийский орден Мевлеви. Однако вместо того, чтобы стать суфийским шейхом, Яган начинает развивать свою собственную практическую философию — “Этос Благородных" или Уорк Хабзэ. В течение своего развития в качестве духовного лидера он заново пересматривает значение суфизма, ислама и христианства для самого себя. Этот процесс пересмотра прошлого в контексте иммиграции приводят Мурата Ягана к духовной трансформации, в ходе которой все большее значение начинает играть его собственная культурная традиция, корнями уходящая к Кавказу.

\section{1. Аутентичность, этническая идентичность и легитимность}

В мультикультурном поле Канады этническое происхождения Мурата Ягана стало его активом. Глубокие личные познания суфизма и Хабзэ делают его аутентичным, подлинным представителем этого духовного поля. Подлинность знаний имеет большое значение в современном западном мире, наполненном эрзацами псевдодуховности. Неизвестная черкесская традиция привлекла множество учеников. Изучение черкесских танцев добавило еще один уровень аутентичного характера Хабзэ, сделав его привлекательным для людей, которые неоднозначно относились к исламу как источнику суфизма. Однако для самого Ягана аутентичность не играла роль инструмента привлечения последователей. Он открывает для себя и своих учеников уровни духовности, ведущие за пределы легитимности открытой заново древней духовной доктрины. Продвижение Мурата Ягана от суфизма к древнему учению Хабзэ, приложение этого учения к западной среде стало характерным примером переработки философских идей, включающим в себя культурный обмен в контексте иммиграции и мультикультурализма. Анализ духовной автобиографии Ягана и других опубликованных материалов с его участием ясно демонстрируют его полное осознание своей аутентичности, позволяющей заново оценить собственное культурное и 
духовное наследие, осознать себя подлинным представителем черкесского Кавказа, “последним старейшиной”. Он по-новому оценивает не только как инструментальный ресурс Хабзэ, но и его этические концепции, которые непрерывно усиливают собственную внутреннюю мощь, способствуют процессу понимания самого себя: «Я пришел к выводу, что древняя черкесская традиция ...которую сам считал слишком примитивной, оказалась сутью всех остальных учений”. В его сознании древнее учение Хабзэ оформляется в качестве новой концепции, абсолютно релевантной современной духовности Северной Америки, и при этом украшенной многочисленными аспектами черкесской культуры. Комбинация аутентичности, идентичности и лигитимности обеспечивает распространение его идей двумя десятилетиями позже по трем различным каналам: в строительстве местной общины, основанной на принципах Хабзэ, через диаспору и оставшихся на исторической родине последователей; а также всех тех, кто интересуется суфизмом и новой духовностью. Все три канала работают одновременно и выстраивают мост из личного духовного опыта древней кавказской традицией и современностью. Дискурс Ягана демонстрирует, что традиция Хабзэ оценивается им лично как учение высшего, универсального уровня. Говоря о возможностях Запада, он подчеркивает его возможности для превращения планеты в мирное, гармоничное и любвеобильное место с целью развития бесконечных творческих способностей человека. Он уверен, что надрелигиозный характер Хабзэ позволяет адаптировать это учение к современному культурному окружению, например, к христианской Канаде. В то же время эти идеи открывают путь к признанию черкесской культуры, которая гораздо более древняя, чем христианство и ислам.

Яган применяет Хабзэ, во-первых, для восстановления баланса между телом и душой современного человека, с целью пробуждения его латентных творческих способностей, установления контакта с космическим источником творческой энергии. Во-вторых, с помощью Хабзэ он предпринимает попытки возродить такие утерянные на Западе человеческие качества, как отвага, сострадание, любовь, альтруизм и надежда. Называя свое учение «Этос Благородных», Яган подчеркивает наличие в нем нравственных императивов - сердцевины черкесской культуры. Мурат вводит в употребление ключевой абхазский термин “алейшва" - кодовое слово для набора этических правил поведения. Алейшва включает в себя такие нравственные 
императивы, как ответственность, вежливость, рыцарство, благородство, честность, скромность, гостеприимство, отвагу и др. Яган подчеркивает, что на протяжении всей истории черкесский этикет притягивал и изумлял визитеров, исследователей и торговцев из соседних стран и Европы. Алейшва, объясняет Мурат Яган, это всеобъемлющий черкесский способ демонстрации безусловной любви на всех уровнях: уважение, почтение и забота о старых людях, сострадание, ответственность в отношении детей, забота о нуждающихся, сексуальное воспитание и наставничество, отношение ко всем жизненным проблемам с отвагой, терпением и юмором. Яган описывает Хабзэ как “этос ежедневного поведения, нравственных норм и коллектиное обучение”. Для Ягана сутью Хабзэ является гнозис или эзотерическое знание. Он рассматривает жизнь в виде единого континуума, без дифференциаций на этот мир и потусторонний мир, рай или ад, поощрений и наказаний. Хабзэ, в терминологии Ягана, это «кавказская йога», термин, который он, возможно, позаимствовал у Конта Валевского, который описывал многочисленные дыхательные практики ранних и средневековых спиритуалистов.

\section{2. О соотношеннии Хабзэ и суфизма}

Яган подчеркивает, что Хабзэ не связано ни с одной конкретной религией или системой верований. Кроме того, Хабзэ - это не язычество. Ни абхазы, ни адыги не поклонялись каким-либо изображениям Бога, но только силе, красоте и энергии природы, все объекты которой являются лишь рефлекторами вечной творческой силы единого Бога. До конца жизни М. Яган имел весьма критическую точку зрения на развитие и интерпретацию ислама, аргументируя это тем, что если бы Коран был правильно понят и мудро истолкован, “в исламе не осталось бы места для фундаментализма и фанатизма”. Позитивное отношение к христианству и исламу было высказано им только в двух аспектах. В христианстве - это фигура самого Иисуса Христа, которого он считал символом любви, вершиной “человека завершенного” в контексте учения Хабзэ, в исламе - суфийское стремление к пониманию сути явлений и социальный альтруизм. Более того, Яган настаивает на том, что мистическая традиция черкесов повлияла на формирование суфийских орденов и способствовала мистической инициации Д. Руми через его мастера Шамса Табризи. Установив духовную генеалогию, в которой Хабзэ отводится роль основы и вдохновляющей силы 
в любом религиозном и культурном контексте, Яган возносит Хабзэ на уровень ценной для Запада духовной традиции. Этим самым он преодолевает историческую ограниченность суфизма рамками исламской догматики. Более того, он замечает, что современные версии суфизма стали для современного человека слишком туманными и часто вводят в заблуждение.

\section{3. Общественное видение и практика}

Духовное развитие личности предполагает ее вовлеченность в общественную деятельность, постулирует Мурат Яган. Общность единомышленников - это самый главный элемент Хабзэ, тема, которой он посвящает целую книгу. Только единомышленники, люди, наделенные общими интересами, делающие общее дело, способны создать подлинное сообщество на основе центральной идеи черкесской общины - “Один за всех - все за одного”. Общие цели и общее дело в современном мире должны быть общечеловеческими, раскрывающими творческие аспекты личности во благо всего общества, во благо всего человечества, а не ограниченной группы людей. Второй важнейший компонент социального руководства в учении Хабзэ - это роль старейшин. Каждый старейшина до конца своих дней остается активным членом общности. Старейшина - это связующее звено между прошлым и настоящим, наводящее порядок и гармонию. Привилегированный статус старейшины распространяется и на семейные отношения: дед является главой семьи и источником духовного вдохновения, символом безопасности, доверия, сострадания и любви.

\section{4. Заключение}

В настоящее время работы М. Ягана переведены на русский, греческий, испанский, португальский и турецкий языки. Эволюция идей Мурата Ягана от устной традиции к печатному слову, ее нарастающее распространение на Западе обеспечены подлинностью Хабзэ как целостного духовного учения, его способностью менять свои формы, сохраняя духовную суть; способностью органично существовать и развиваться в условиях мультикультурализма, противодействуя плавильному котлу этнического единообразия. 


\title{
Губжоков М.Н.
}

\section{В поисках идеального государства: платоновские мотивы в трудах Султана Хан-Гирея}

\begin{abstract}
Аннотация: Автор рассматривает философские представления об общественном благе, долге и справедливости выдающегося адыгского интеллектуала Султана ХанГирея. Подобно античному философу-идеалисту Платону, Султан Хан-Гирей свою жсизнь потратил на поиск путей преобразования адыгского общества, стремясь к идеальному мироустройству, подчиненному законам справедливости.

Ключевые слова: Платон, Хан-Гирей, античные мотивы, идеальное мироустройство, законы справедливости, адыгское общество.
\end{abstract}

Идея поиска оптимального общественного устройства с глубокой древности сопровождала людей - с того самого момента, когда человек впервые ощутил себя органичной частью социума, мириадами нитей связанной с другими людьми. Постепенно усложняющиеся общественные структуры, со временем принявшие законченную форму государственных институтов, были пронизаны насилием, вызывая у людей ощущение дисгармонии окружающего мира и порождая чувство протеста, принимавшего самые разные, а иногда и просто разрушительные формы.

Однако мысли о несовершенстве общественного устройства были свойственны не только низам общества, но и незаурядным интеллектуалам, способным облечь свои сомнения и рассуждения в блестящую полемическую и литературную форму. Многие из них делали смыслом своей жизни поиск нового идеала взаимоотношений между людьми и окружающим их социальным ландшафтом.

Идеалисты и прагматики, создатели новых религиозных учений и философских систем, оппозиционеры и представители правящей верхушки - разделенные пространством и временем, они зачастую генерировали поразительно схожие идеи.

Представления о справедливости, общественном благе, долге правителя, пределах допустимого насилия с целью обуздания людских пороков, взаимоотношения между основными стратами населения будоражили воображение гениальных умов разных эпох, а будучи положенными на бумагу, становились неотъемлемой частью «золотого фонда» философской и общественно-политической мысли человечества. Даже спустя тысячелетия поразительная сила духа, благородство намерений и интеллектуальная мощь диалогов Платона поражали воображение его последователей 
и заставляли вновь и вновь обращаться к так и не разрешенным проблемам коллективного бытия.

Эта своеобразная перекличка через тысячелетия явственно прослеживается и в творчестве выдающегося адыгского интеллектуала Султана Хан-Гирея (1808-1842), вся жизнь которого была посвящена неустанному поиску места его народа в новом мире, формирующемся на разломе эпох - традиционной и имперской. Старая, феодальная Черкесия, сотрясаемая социальными конфликтами и гибнущая в пламени Кавказской войны, должна была неизбежно уйти в прошлое. И Хан-Гирей, раньше, чем многие, осознав неотвратимость этого, постепенно, шаг за шагом, стал создавать образ будущего, который должен был прийти на смену старому миру - образ, содержащийся на страницах его научных трудов, политических проектов и художественных произведений. Исключительно высокое служебное положение, которое он приобрел в зените своей карьеры, давало ему возможность донести свои идеи до военнополитического истэблишмента Российского государства.

Несчастливая судьба проектов Хан-Гирея, сочтенных несоответствующими местным политическим реалиям и из высших соображений отвергнутых имперским руководством, как нельзя лучше символизирует судьбу самого Хан-Гирея. Сама его жизнь была сродни высокой античной трагедии. Подобно Платону, он всю свою жизнь потратил на поиск путей преобразования адыгского общества, стремясь к идеальному мироустройству, подчиненному законам справедливости.

Мы не знаем доподлинно, был ли знаком Хан-Гирей с трудами Платона ${ }^{1}$, имевшими широкое хождение в Россииㄹ, но некоторые строки адыгского интеллектуала звучат совершенно «по-платоновски», как будто пером Хан-Гирея водила рука античного мудреца.

\footnotetext{
${ }^{1}$ Специалисты пока не могут с уверенностью сказать, какое именно учебное заведение окончил Хан-Гирей и по каким программам он обучался. Однако круг его интересов, широта познаний, степень владения им литературным русским языком позволяют допустить, что это было учебное заведение с гимназической или лицейской программой. Именно здесь могли сформироваться его представления об истории греко-римского мира и основных постулатах античной (в частности, платоновской) философии. Естественно, что классическое образование (даже в неполном его варианте) могло дополняться постоянным самообразованием Хан-Гирея, ведь в его эпоху основные знаковые труды греческих авторов (Гомера, Геродота, Фукидида, Ксенофонта и мн. др.), включая сочинения Платона, были уже изданы в русских переводах. Еще одним источником погружения в классическую древность для Хан-Гирея наверняка стала русская литература, пронизанная античными мотивами, живейшим примером чего может являться творчество А.С. Пушкина [1].

В то же время, примечательно, что в трудах Хан-Гирея содержится единственное упоминание имени конкретного философа, и им оказался не античный автор, а Ж.-Ж. Руссо, причем «женевский философ» упомянут вне всякой связи с постулатами представляемой им науки [2, с. 306].

2 Труды античного философа входили в круг чтения интеллектуальной элиты России, интересовавшейся общественно-политической проблематикой. Так, например, Д.П. Якубович, ссылаясь на В.И. Семевского, утверждает, что члены декабристского Южного общества (и среди них Пестель) увлекались «Государством» и «Законами» Платона [1, с. 153]. 
В своем творчестве Хан-Гирей многократно обращался к античным мотивам, вплетая их в черкесские сюжеты ${ }^{3}$. Подобный шаг был вполне объясним с точки зрения читательской аудитории, к которой были обращены его труды. Античная символика была прозрачна, являясь неотъемлемой частью интеллектуального багажа каждого образованного человека той поры, особенно - столичной знати, в кругах которой приходилось вращаться Хан-Гирею и для которой «образы, ситуации и персонажи мифологии, латинские эпиграфы и изречения являлись в пушкинское время естественным внешним орнаментом школьного и дворянско-салонного образования» $[1,94]$.

Но для Хан-Гирея античные мотивы отнюдь не являлись бесхитростной демонстрацией его европейской образованности, будучи способом решения вполне определенных задач. Проводя параллели между греко-римской эпохой и периодом «классической» Черкесии, автор усиливает изобразительное решение конкретного фрагмента текста, порождая у читателя вполне ожидаемые ассоциации и соответствующие эмоции.

«Величавая древность» Греции и Рима всплывает на страницах его трудов, чтобы отчетливее оттенить «благородную старину» земли адыгов, воспетую в песнях и преданиях, являвшихся неотъемлемой частью исторических представлений соплеменников Хан-Гирея. Так, согласно приводимым Хан-Гиреем фольклорным свидетельствам, бжедугский князь Батчерий Хаджимуков, получивший смертельную рану на поле Бзиюкской битвы и узнавший, что «враги его родины разбиты наголову, произнес с радостью, как римлянин [здесь и далее курсив наш - М.Г.]: “Теперь я умру спокойно!.. "» [2, с. 472]. В старинной песне, посвященной геройской гибели Каита, «певец влагает в уста неустрашимого наездника слова, достойные отваги спартанцев» [2, с. 386]. Представления черкесов о славе и способах ее достижения доказывают, по мнению Хан-Гирея, «некоторым образом сходство нравов этого народа с нравами спартан» [2, с. 276]. О матери братьев Ешаноковых, поразительная сила духа которой сохранилась в памяти адыгского народа, Хан-Гирей пишет как о «женщине ... не уступающей гражнданкам Спарты и Рима» [2, с. 274].

\footnotetext{
3 Чего стоит одно только лирическое отступление из «Черкесских преданий», посвященное воображаемому балу-маскараду: «Вы тут ищете жену свою в образе амазонки - если вы любите воинственных женщин, или под одеждою римлянки - если вы обожаете величавую древность, или под эфирным нарядом сильфиды - если вы любитель мифологии...» [2, 345]. 
В повести «Черкесские предания», построенной главным образом на жанинском фольклорном материале, Хан - Гирей проводит недвусмысленные параллели между Римом и некогда прославленным адыгским княжеством Жанэ: «Рим покорил и ограбил Вселенную. Жанинское поколение гремело и буйствовало в известных ему пределах. Римляне подавлены были собственною своею тяжестью и погибли. Жанинское поколение испытало ту же участь. История древнего Рима поучительна и поражает удивлением Европу. Громкие предания об отважном поколении жжанинском изумительны для нас, и мы без восторга не можем слушать древние его песни...» [2, с. 322-323].

Подобно «героическим временам» Греции и Рима, ставшим «классикой» европейской цивилизации, для адыгов эпохи Хан-Гирея «классическими» являлись предшествующие им столетия, история и нравы которых, сохраненные в фольклоре, для Хан-Гирея и его современников являлись образцами для подражания и предметом восхищения. «Теперь лишь темные предания об отчаянных и рыцарских их подвигах приводят в ужас и удивление настоящее поколение черкес» - этот пассаж, посвященный жанинцам, Хан-Гирей мог бы отнести ко всем адыгам той далекой эпохи ${ }^{4}$.

Для Хан-Гирея, посвятившего немало страниц своих трудов уже несуществовавшему в его время княжеству Жанэ, прикосновение к истории последнего было равнозначно обращению к «золотому веку» адыгской истории - тоже далеко не идеальному, но во многом более гармоничному, чем современность.

Хан-Гирей, еще в отрочестве осознавший несовершенство человеческого общества, ужасавшийся уровню насилия в адыгском социуме [4, с. 71-72] (в общем-то типичному для всех феодальных сообществ), являвшийся свидетелем перманентного разрушения основ княжеской Черкесии и осуждавший лицемерие и политический эгоизм ее элит, стремился обратиться к прошлому, которое, согласно универсальной идее «предки лучше нас», чище и благороднее.

Постепенно деградируя и утрачивая заложенные еще в пору «золотого века» высокие стандарты общественного устройства, люди теряют изначальную гармонию и

\footnotetext{
4 Любопытно, что если в спартанском образе жизни Хан-Гирей ценит прежде всего воинскую доблесть и патриотизм, то у Платона на протяжении его жизни восприятие Спарты менялось. Если в «Государстве» он однозначно относит спартанскую тимократию к отрицательным (извращенным) формам общественного устройства, то в «Законах» Спарта превозносится за «консерватизм тамошних государственных форм и их тысячелетнюю неподвижность» [3, 166]. Думается, что этот тезис весьма понравился бы Хан-Гирею, высоко ценившему общественную стабильность! 
ожесточаются, следствием чего, по Хан - Гирею, становятся «безначалие, междоусобицы и раздоры», торжествуют анархия и право сильного 5 .

С восхищением описывая «жанинское поколение в эпоху его могущества», ХанГирей откровенно пишет о производимых им «опустошительных набегах» на ближних и дальних соседей, притеснениях горных племен, «бешеной жажде воинственных потех». Конечно, автор, как человек уже европейского склада мышления, отнюдь не в восторге от стандарта насилия жанинского периода, но считает, что эти качества «питомцев бурной свободы» с лихвой компенсируются «отвагой, гордостью, непокорным духом и пламенным характером» древних жанинцев, столетиями прикрывавших остальную Черкесию от крымской угрозы [2, с.322]. «О святая старина! Зачем пережили мы благородные твои обычаи!..» - восклицает он, восторгаясь этикетной утонченностью героев «Черкесских преданий», их рыцарским поведением, возведенным в культ почитанием женщин [2, с. 329].

Но для Хан-Гирея прошлое привлекательно не только в силу романтических пристрастий автора, не чуравшегося высокого слога. Эпоха «классической» Черкесии мыслилась ему как благодатное время социальной стабильности и жесткого соблюдения феодального договора всеми сословиями. И это не случайно, поскольку общественный переворот рубежа XVIII - XIX столетий нанес сокрушительный удар по аристократии, владельческие прерогативы которой были существенно ограничены (у горных адыгов) либо, как в равнинных княжествах, находились под угрозой перманентного давления идей эгалитаризма.

Для самого Хан-Гирея именно разрушение основ феодального строя с его жесткой соподчиненностью и исполнением раз и навсегда заданных социальных ролей, являлось одним из показателей деградации общественного устройства Черкесии (и здесь мы опять слышим отчетливые платоновские интонаций ${ }^{6}$, расшатывающим и дезорганизующим все элементы традиционного «образа управления».

\footnotetext{
5 Примечательно, что для самих античных греков, якобы живших в «золотом веке», эта благодатная мифическая пора отодвигалась еще дальше в глубь времен, как линия горизонта, и «золотой век» был предметом воздыхания уже современников и предшественников Платона. Как сожалеет поэт Гесиод, живший за 400 лет до Платона, о том, что «ему приходится жить в железный век, когда господствует право кулака, не уважают старших и бедный дрожит в когтях богатого» [3, 143]. С тех времен ничего не изменилось, и вот уже ХанГирей, вторя Гесиоду, оплакивает «железный век» Черкесии: «корыстолюбие часто утоляет позорную свою жадность, несправедливость в гнусном торжестве своем попирает священную истину и несчастный праведник, которого вся вина в слабости, стонет под бременем угнетения» $[2,126]$.

6 Платон называл это по-другому, но для него страшнейшим грехом было именно присвоение чужих прав и обязанностей, когда, например, чернь будет претендовать на управление общиной: «Государство мы признали справедливым, когда имеющиеся в нем три различных по своей природе сословия [ремесленники, стражи и правители - М.Г.] делают каждое свое дело» [5, 155] и «вмешательство ЭТНОФИАОСОФИЯ АДЫГОВ: ОТ МИФА К АОГОСУ : 
Естественно, что у современных историков, взирающих на события первой половины XIX в. с высоты прошедших столетий и привыкших мыслить глобальными категориями, социальные потрясения, волновавшие Хан-Гирея и его современников, всего лишь отражение кризиса адыгского феодализма и процессов демократизации, живое творчество масс, попытки выйти за пределы привычных общественных форм и Т.Д.

Но для Хан-Гирея, способного не только к масштабным обобщениям, но и умению взирать на историю через призму, как бы мы сейчас сказали, структур повседневности, за совокупностью разнородных фактов всегда был слышен голос обычного человека, страдающего от несовершенства общественного устройства и в силу этого становящегося жертвой «кровавых драм в земле прекрасной, но брошенной судьбою на произвол тревог и кровавых бурь безначалия» [2, с. 515]. И это умение подняться над узкосословными интересами и увидеть проблему Черкесии в целом, тоже делает ему честь, лишний раз демонстрируя государственный уровень его мышления.

Основной вывод, к которому должен был в результате своих размышлений неизбежно прийти Хан - Гирей - о невозможности стабилизировать положение в стране, используя только опыт традиционной политической культуры, который либо продемонстрировал уже свою неэффективность, либо был неприменим в конкретных исторических условиях.

Так, хотя Хан-Гирей и считал сильную власть основой любого общественного «порядка и благоустройства» и не раз с уважением отзывался о государственной деятельности легендарных адыгских князей, он, тем не менее, даже не рассматривал возможность нового объединения страны «сверху» под властью одного вождя, сознавая, что Черкесия, истерзанная социальными конфликтами и княжескими усобицами, не в состоянии такого общенационального лидера породить и принять. К тому же, даже появившись и ступив на путь централизации страны, такая личность, обладающая решимостью и волей Инала Светлого или Асланбека Кайтукина, неизбежно должна была бы покрыть адыгскую «землю злодеяниями ценою достижения верховной власти». Ясно, что Хан-Гирей, подобно Платону, органически 
неприемливший тиранию и идефиксом которого было приведение его народа «в гражданственное состояние кроткими мерами с возможным избежанием кровопролития», даже и помыслить о таком историческом сценарии не мог.

Иной путь, который был в начале XIX в. предложен лидерами «шариатского движения» в Кабарде - добровольный отказ от власти и переустройство общества по законам шариата [6, с. 406-409, с. 421-423] - также был неприемлем для Хан-Гирея, который, хотя и был мусульманином, все же оставался частью своего класса. Он не забывал, что именно под влиянием коранической доктрины всеобщего равенства в Бжедугии в 1828 г. произошло временное разрушение сословного строя, а в «демократических» обществах Черкесии дворянство, которое и без того лишилось «прежнего своего могущества», окончательно утратило свои привилегии, когда «шариат исламизма ... сравнял права каждого жителя этих племен» [2, с. 180]7.

Для Хан-Гирея любая демократия - шариатская (как в Кабарде) или светская (скроенная по лекалам «народного правления» горских обществ Западного Кавказа), призывающая к «пагубному равенству», априори является неприемлемой. При этом он признает право «демократических» обществ на существование и саморазвитие, отдает должное продуманности норм управления в «недрах их отечества». Демократия для Хан-Гирея плоха не сама по себе, а в силу потенциальной угрозы для Черкесии в целом - по причине неизбежного сосуществования ее с княжескими владениями, для которых «народное правление» всегда будет источником нестабильности, примером несоблюдения феодального договора, образцом и побудительным мотивом отрицания строгой иерархии власти. Опасность состоит и в непомерных требованиях черни получить права управления, к чему она не готова ${ }^{8}$.

Следующим логичным шагом Хан-Гирея должен был стать поиск иноэтничной оптимальной модели общественного устройства, избавленной от недостатков черкесской системы управления эпохи кризиса - а стало быть, характеризующейся как

\footnotetext{
7 Дальнейшая история Черкесии подтвердила опасения Хан-Гирея. Попытки наибов Шамиля, и особенно - Магомет-Амина перенести на Северо-Западный Кавказ политические традиции имамата, привели к фактической ликвидации власти старой аристократии на подконтрольной ему территории.

8 «Чернь везде безумна и не знает границы свободы и буйству» $[2,315],-$ откровенно пишет Хан-Гирей. Ср. еще раз с идеей Платона, согласно которому общественная справедливость заключается в гармонии составляющих государство сословий, а также в том, чтобы каждое низшее сословие (и каждый гражданин в нем) повиновались руководству высшего, не стремясь занять несвойственное ему место $[7,547]$. 
сильной (желательно централизованной) властью ${ }^{9}$, так и «человеколюбивыми законами просвещенного государства».

Вряд ли таким образцом могла бы стать соседняя Турция. И дело здесь не только в нелояльности для офицера российской службы даже признать ее таковой. Сама турецкая действительность не соответствовала глобальным целям Хан-Гирея. И пусть столь ценимое им просвещение уже имеет место в державе Османов, но хроническая нестабильность, сопровождаемая периодическим и ужасным кровопролитием, вряд ли могла привлечь Хан-Гирея как прообраз «идеального государства» [9]. Турция не может быть идеалом и по другой причине - ведь именно из этой державы были привнесены исламистские идеи, подрывающие законную власть старой элиты Черкесии.

Следовательно, по мысли Хан-Гирея, только Россия может являться эталоном разумного правления. Но для того, чтобы империя распространила на адыгов те блага, которыми пользуются ее подданные, необходимо, чтобы процесс подчинения ею Черкесии, который идет уже многие десятилетия, пришел к логическому завершению. Именно этим объясняется готовность Хан-Гирея к исполнению ответственной миссии - отправиться на Кавказ, предшествуя визиту императора Николая I - с целью приведения в подданство адыгов и других «немирных горцев», которые либо открыто противостояли российской армии, либо находились в состоянии шаткого «замирения». Иного выбора у адыгов, по убеждению Хан-Гирея, просто не остается. Их судьба предрешена северным колоссом - «могущественнейшей империей, от влияния которой сия земля [Черкесия - М.Г.] должна, по обстоятельствам, или получить благоустроенное существование, или погибнуть» [2, с. 597]. Две силы борются и взаимодействуют в его сознании - долг давшего присягу имперского офицера и, как он сам пишет, «чувства любви к земле, где я получил жизнь» и на «благоденствие» которой «под благотворной властью монарха» он надеется [2, с. 597].

\footnotetext{
9 «Где нет власти единодержавной, - пишет Хан-Гирей, - там с искони нет согласия: там верховная власть, находящаяся в руках буйных партий, превращается в пагубную страсть, которая, разливая свирепое пламя междоусобия в народе, производит кровавые мятежи, что случалось во многих странах, не подвластных единодержавию, что случилось и в Черкесии» [2, 178]. Примечательно, что Хан-Гирей, не раз писавший в своих работах о «беспрестанных» «беспокойствах», «буйных заботах», «кровавых бурях», потрясающих Черкесию, подавал их как следствие сугубо внутренних проблем, никоим образом не упоминая о значительное доле ответственности за них российской стороны. А ведь именно вмешательство империи во внутриадыгский конфликт провоцировало его обострение, а навязывание адыгам российских моральных и правовых установок приводило к деформации и еще большему внутреннему рассогласованию общественных институтов Черкесии, утрачивавших свою функциональность. Аналогичный процесс, гораздо раньше начавшийся в Кабарде и развивавшийся на фоне российской экспансии, привел все регуляторы общественной жизни к полному краху [8].
} 
Заранее зная, на что способна российская военная машина, Хан-Гирей тщательно выписывает проект поэтапного, максимально плавного и наименее болезненного подчинения адыгов империи - «Некоторые мнения о мерах и средствах, для приведения черкесского народа в гражданственное состояние, кроткими мерами с возможным избежанием кровопролития» (так именуется заключительная глава «Записок о Черкесии»). Реализация этого обширного плана должна была в корне изменить не только «образ управления», но и образ жизни, и даже сам «образ мыслей» черкесов. Это был грандиозный проект, достойный тех великих князей, имена и деяния которых ХанГирей с восхищением упоминает в своих трудах. И в то же время, это была величайшая в черкесской истории утопия, достойная пера самого Платона.

Стержневой фигурой его проекта является император Николай I. Многочисленные славословия в адрес царя, рассыпанные автором по тексту «Записок» (и, особенно, заключительной главы) в совокупности рисуют образ человеколюбивого и «мудрого монарха», воплощение «беспримерного великодушия», царствование которого «озарено блеском славы и величия». Все эти эпитеты, неоднократно повторяясь, создают ощущение некой мантры, заговора, посредством чего Хан-Гирей, с одной стороны, старается еще и еще раз уверить себя в безошибочности собственного плана, a с другой - пытается сконструировать некую реальность, в которой воображаемый Николай I, следуя подсказкам автора «Записок», возводит черкесов «на степень счастия гражданственности». И подобно тому, как Платон пытался вылепить из сиракузских тиранов «философов на троне», научив их править справедливо и добродетельно, так и Хан-Гирей словно пытается достучаться до сознания императора, взывая к его мудрости и благородству. Для Платона, как известно, его поездки на Сицилию закончились полным фиаско и отвращением к дальнейшим занятиям государственными делами [10]. Хан-Гирей, отстраненный от большой политики и рано вышедший в отставку, до конца своей короткой жизни терзался угрызениями совести, что не сумел повлиять на кавказскую стратегию императора.

Вряд ли у этого краткого романа Хан-Гирея с российской властью мог быть иной финал. Трудно сказать, чего здесь было больше - искреннего заблуждения и самообмана молодого политика? Или лицемерия петербургского высшего света и самого императора, сугубо практический интерес которых маскировался фальшивым 
вниманием к экзотической фигуре туземного князя? Ведь особый статус конвойцев Хан-Гирея вкупе с его исключительным положением как командира полуэскадрона и флигель-адъютанта Николая I, ставшие причиной ловушки восприятия, собственно, и были на это рассчитаны - подобно театральным декорациям, ограждавшим выходцев с Кавказа от суровой реальности николаевской поры. Тем печальней было позднее прозрение Хан-Гирея, разочарование которого видно не только по его уходу с российской службы - оно прорывается и на страницы его поздних трудов.

Апеллируя к императору, Хан-Гирей взывает именно к тем его качествам, которые сам ценил выше прочих. Первейшим из них он почитает мудрость. Но это мудрость, понимаемая не в платоновском духе, не высшее знание созерцателя небесных сфер (что предписывал делать правителям античный философ), не отстраненность, а мудрость сопереживания, мудрость человеколюбия, что только и дает правителю моральное право властвовать над огромными массами людей.

Еще одно высоко ценимое Хан-Гиреем качество - справедливость. Это одно из ключевых понятий в его картине мира, употребляемое им и применительно к юридической системе, и как морально-нравственная категория, и понимаемое как практическая ценность. По его мнению, справедливость должна пронизывать все общество и быть присущей всем его слоям, работая на благо каждого человека.

Стоит ли говорить, что подход Хан-Гирея к идее справедливости (государство для гражданина) более человечен и в корне отличался от справедливости николаевской эпохи, в которую каждый подданный императора и каждый состоящий из них народ лишь безликая деталь государственного механизма. Как это напоминает справедливость платоновского «идеального государства», в котором каждый человек лишь пассивное орудие в руках правителя [11, с. 9]!

Подобно Платону, конструирующему свое гармоничное общество из нескольких сословных групп, Хан-Гирей смело прибегает к идеям социальной инженерии, посредством которой планирует переформатировать старые общественные группы и отношения.

Под пером Хан-Гирея, словно под рукой демиурга, возникают новые, доселе неизвестные в Черкесии, сословия - купцы и профессиональные ремесленники. Воображаемая карта новой Черкесии покрыта городами, которые зарождаются в ЭТНОФИАОСОФИЯ АДЫГОВ: ОТ МИФА К АОГОСУ : 
полном соответствии с историческим опытом России и Европы, кристаллизуясь вокруг административных центров (махчематств). Действуют промышленные предприятия, разрабатывающие природные ресурсы Черкесии, ставшей «богатейшей провинцией Южной России» [2, с. 287].

Черкесская система феодального вассалитета, в новых условиях уже ненужная (и более того, опасная своим откровенно военным характером), должна быть отменена; высшее дворянство, получив землю в собственность, должно превратиться в обычных помещиков, а низшее - окрестьяниться.

Bсе это вместе взятое должно смягчить сурово-аскетические нравы черкесов, привить им новые материальные потребности и образ жизни, приблизить к общероссийским стандартам.

Новый общественный строй будет, конечно, аристократическим, который ХанГирей, подобно Платону, считает наилучшим. Однако состав этой элиты должен значительно обновиться по сравнению с феодальными временами - так, входящие в органы управления наиболее авторитетные главы княжеских и дворянских кланов будут вынуждены делить власть с верхушкой крестьянских старшин и священнослужителями (которые, как известно, зачастую были самого низкого происхождения). Фактически, это уже аристократия не столько по крови, сколько по духу.

Новое общество сможет стабильно развиваться только с новыми людьми. Огромное значение Хан-Гирей придает просвещению - этот термин по частотности употребления в «Записках о Черкесии» явно опережает другие. Дабы вписать черкесов в общественные структуры империи и сделать их конкурентоспособными ${ }^{10}$, Хан-Гирей предлагает открыть учебные заведения, где преподавание светских дисциплин должно вестись на русском языке. Адыгская письменность, любимое детище Хан-Гирея, хотя и не упомянута в проекте как средство обучения, тоже явно предназначена ее создателем для высоких целей просвещения народа и формирования национальной интеллигенции.

Постоянно присутствующие в тексте Хан-Гирея приметы военного времени не позволяют нам забыть, что его проект создавался в 1836 г. - в разгар Кавказской войны,

\footnotetext{
${ }^{10}$ А в том, что это будет именно так, Хан-Гирей не сомневается, неоднократно в своих трудах подчеркивая, что черкесский народ «одарен от природы многими способностями ума и духа». 
когда российская граница еще не была даже передвинута вглубь Закубанья - на Лабу. Сознавая, что кавказская политика империи на перепутье, Хан-Гирей спешит перехватить инициативу у российского командования, предлагая проект присоединения Черкесии, осуществимый, по его мнению, без значительных человеческих потерь и материальных затрат. В данном случае он уповает на то, что жители равнинных княжеств с готовностью согласятся на т.н. «новый порядок управления», противящихся же (главным образом - горцев) придется принуждать к его принятию.

И эта готовность принудить народ к счастью показывает нам Хан-Гирея как жесткого прагматика. В то же время предчувствие неизбежности кровопролития (пусть даже и ограниченного, на что он надеется) отравляет совесть Хан-Гирея, делая эту моральную дилемму неразрешимой, ведь проблема правомерности применения насилия для воплощения в жизнь идеалов, поставленная еще Платоном, всегда была одной из сложнейших в социальной философии [12, с. 214], а в реальной политической практике всегда была сопряжена со значительными нравственными издержками.

И эту ответственность Хан-Гирей готов принять на себя. В своем проекте он предусматривает высокий пост «Попечителя над просвещением и образованием черкесского народа и водворения между ними спокойствия кроткими мерами» с весьма значительными полномочиями, который, вероятнее всего, надеялся занять сам.

И действительно, вряд ли кто-то более, чем он сам, подходил на этот пост. Само время, в которое он формировался, казалось, предназначало его для какой-то особой, более высокой, чем у других, миссии.

Человек, воспитанный в лучших адыгских традициях и сумевший впитать лучшее из культуры российской, он одинаково комфортно чувствовал себя в обоих, столь разных, мирах. Богатый жизненный и профессиональный опыт, который он, несмотря на молодость, приобрел в Черкесии и на российской службе, позволял ему быть связующим звеном между этими столь непохожими цивилизациями, сошедшимися в смертельном поединке.

Живи Хан-Гирей в античную эпоху, вероятно, он мог бы стать для самого Платона одним из персонажей его диалогов. Мудрец легко разглядел бы в черкесском аристократе столь почитавшуюся эллинами калокагатию (истинную гармонию), в духе которой воспитывался и сам Платон - идеальное сочетание внешнего и внутреннего, 
великолепную соразмерность, немыслимую без всесторонней образованности и нравственного благородства [3, 8-9]. Соответствуя жестким платоновским меркам, ХанГирей соединял в себе качества, непременные для идеального правителя-философа «страстное влечение к знанию» и «правдивость, решительное неприятие какой бы то ни было лжи, ненависть к ней и любовь к истине» [5, с. 208]. Великий Платон, жизнь которого являла собой цепь разочарований, легко понял и объяснил бы трагедию ХанГирея, нравственные качества и устремления которого пришли в несоответствие с самим духом николаевской империи, ведь по Платону, тот, кто приблизился к природе истинного философа, обычно не находит себе места при извращенном государственном устройстве [13, с. 360].

С высоты прошедшего времени нам яснее видится как величие деяний Хан-Гирея, так и заведомая неосуществимость его планов по переустройству Черкесии под эгидой Российской империи.

Эпоха Кавказской войны была не самым лучшим временем для подобных социальных экспериментов, а держава Николая I вряд ли могла служить образцом для подражания и партнером в поиске справедливого общественного устройства.

Проект Хан-Гирея стал одной из самых ярких утопий со времен Платона - и по содержанию, и по внутреннему накалу страстей, и по тем побудительным мотивам, что подвигли его создателя на написание «Записок о Черкесии». Его проект, даже будучи заведомо невыполнимым, содержал в себе столько «несвоевременных» и неудобных для имперского руководства идей, что был засекречен и более чем на столетие погребен в недрах военного ведомства.

В силу этого, тексты Хан-Гирея с огромным запозданием дошли до своего читателя и, к сожалению, в отличие от других аналогичных трудов, не оказали влияния ни на практику государственного строительства XIX века, ни на позднейшую общественно-политическую мысль. Но от этого духовный подвиг Хан-Гирея не стал менее осязаемым. Его личность, значимость которой давно уже переросла рамки адыгского мира, может быть заслуженно причислена к когорте выдающихся интеллектуалов XIX века. 


\section{ЛИТЕРАТУРА:}

1. Якубович Д.П. Античность в творчестве Пушкина // Пушкин: Временник Пушкинской комиссии. - М.; Л.: Изд-во АН СССР, 1941. - Вып. 6. - С. 92-159.

2. Султан Хан-Гирей. Избранные труды и документы. - Майкоп: ОАО «ПолиграфЮГ», 2009. - $672 \mathrm{c}$.

3. Лосев А.Ф., Тахо-Годи А.А. Платон. Аристотель. - М.: Мол. гвардия, 1983. - 383 с. (Жизнь замечат. людей. Сер. биогр.; Вып. 723).

4. Губжоков М.Н. К вопросу о происхождении фольклорных сюжетов в трудах ХанГирея // Проблемы сохранения черкесского фольклора, культуры и языка: материалы Международной научно-практической конференции памяти М.И. Мижаева (пос. Нижний Архыз, 26-28 ноября 2014 г.) / сост. М.М. Паштова. Майкоп: «ИП Паштов 3.В.», 2015. - С. 67-85.

5. Платон. Государство. - М.: Академический проект, 2015. - 398 с.

6. Кажаров В.Х. О времени и обстоятельствах учреждения «духовных судов» в Кабарде // Исторический вестник. - Нальчик, 2006. - Вып. III. - С. 398-425.

7. «Государство» // Новая философская энциклопедия: в 4 т. Т. 1. - М.: Мысль. - С. 547-548.

8. Кажаров В.Х. Традиционные общественные институты кабардинцев и их кризис в конце XVIII - первой половине XIX века. - Нальчик: Эль-Фа, 1994. - 440 с.

9. Губжоков М.Н. Черкесское восприятие Османской империи: «турецкие» сюжеты в трудах Султана Хан-Гирея // Journal of Caucasian Studies (JOCAS). - 2016. - Vol. 1, № 2. - S. 177-190.

10.Могилевский Б.М. Платон и сицилийские тираны: Мудрец и власть. - М.: КомКнига, 2005. $-160 \mathrm{c}$.

11.Трубецкой Е.Н. Политические идеалы Платона и Аристотеля в их всемирноисторическом значении // Платон. Государство. - М.: Академический проект, 2015. - C. 5-29.

12.Горелов А.А. Основы философии: Учебник. - М.: Издательский центр «Академия», 2014. $-320 \mathrm{c}$.

13.Асмус В.Ф. Комментарии к диалогу «Государство» // Платон. Государство. - М.:

Академический проект, 2015. - С. 358-397. 


\title{
Паранук К. Н.
}

\section{Философский контекст прозы Нальбия Куека}

\begin{abstract}
Аннотация: Рассматривается философская основа эпики Н.Куека (повесть "Черная гора», роман «Вино мертвых»), определяется кониептуальная философская идея произведений. В образной системе романа выявляются герои с трансиендентным сознанием, наделенные бессмертием и пребывающие на грани реального и ирреального миров. Делается вывод о концептуальности этих образов для реализачии авторского замысла и достижения структурно-семантической целостности художественного текста.

Ключевые слова: Современный адыгский роман, образная система, мифопоэтика, архетипы, трансиендентное сознание, инфернальный мир, бессмертные герои.
\end{abstract}

Творчество известного адыгейского писателя Нальбия Куека характеризуется наличием глубокого философского контекста. Тяга к глубоким философским обобщениям наиболее ярко и масштабно проявилась в прозе писателя, многоплановой, многоуровневой, настроенной на масштабное и глубокое осмысление проблем XX века: человек и история, человек и природа, человек и война, человек и окружающий мир. В них историко-философское мышление автора обретает новые художественные параметры, ярко и художественно убедительно отразив национальный менталитет, национальный опыт, национальную проблематику. Повесть Н. Куека «Черная гора», опубликованная на русском языке, стала весомым вкладом в философскую прозу адыгейской литературы. В ее центре художественное исследование такой вечной философской дилеммы, как добро и зло, спроецированной на реальные исторические события Русско-Кавказской войны XIX века. В повести Н. Куека наметилась тенденция усиления философского начала в осмыслении жизни, сопровождающаяся поисками в области поэтики и стиля, концептуальным изменением отношения к фольклорному наследию.

Эта тенденция прослеживается и в первом его романе «Вино мертвых» (2002г.), где вся национальная история адыгов предстала как целостное повествование, в котором сопрягаются прошлое, настоящее и будущее народа. Критика правомерно оценила его как незаурядное явление адыгской романистики и отмечала, что «Черная гора» и «Вино мертвых» - это новый эпос адыгов, в котором художественное 
исследование истории этноса ведется в едином контексте духовно-нравственного пространства всего человечества.

Роман «Вино мертвых» состоит из семнадцати самостоятельных новелл, объединяющихся в единый непрерывный рассказ о судьбе адыгского народа, его истории, обычаях, традициях, его образе жизни, его мировидении и мировосприятии. Роман имеет три уровня чтения: исторический роман-хроника, роман - миф, философское произведение. Роман имеет сложную композицию: первые две и последние две новеллы апеллируют к мифо-эпическим временам, Нартиаде и сопряжены с циклическим, мифологическим временем и мифологическими персонажами. Остальные новеллы (3 - 15) повествуют о сложной трагической истории адыгского народа, прослеженной на примере рода Хаткоесов. В них отражены линейно-историческое время и реальные события, связанные с самыми драматичными моментами из истории народа, начиная с доистоических времен и завершая современностью.

В них Н.Куек создает образы блистательных воинов: Кунтабеша, Хата, мамлюка Кангура, Предводителя, Дэдэра, Редеда и других, отважных, неустрашимых, беззаветно преданных своему делу, родной земле. По своим художественно-эстетическим характеристикам они ничем не уступают лучшим образцам западноевропейского эпоса Роланду, Сиду, Кухулину. Но судьбы почти всех этих героев складываются весьма драматично и даже трагично, так как они волею обстоятельств вынуждены потратить все свои жизненные силы на войну, разрушение, а не созидание. Этому разрушительному началу в романе противостоят образы сквозных героев три-бабушки, Ляшина, Фэнэса, наделенных бессмертием, а также богочеловека Тлепша.

Эти образы имеют выраженный концептуальный характер и выражают концептуальную для философской основы романа идею бессмертия.

Пространственно-временной континуум романа сложен, многогранен и представляет собой пространство-время мифа. Герои пребывают одновременно в двух планах - реальном и мифологическом, пространство может сжиматься и расширяться до размеров вселенского универсума, а категория времени совершенно свободна: прошлое, настоящее и будущее сосуществуют одновременно в контексте романа. В этом едином потоке времени пребывают одновременно мифологические персонажи, ЭТНОФИАОСОФИЯ АДЫГОВ: ОТ МИФА К АОГОСУ : 
герои фольклора, исторические личности, литературные герои, представляющие становление, расцвет и угасание рода Хаткоесов.

Мудрая три-бабушки - прародительница рода Хаткоесов, которая часто посещает представителей рода Хаткоесов в их снах и жизненных реалиях и дает им мудрые советы. Три-бабушки бессмертна, она является представителем инфернального мира и после смерти навещает мир живых, являясь посредником между миром живых и умерших. О ней ходили легенды, ее «хоронили в ее отсутствие десятки раз» $[1, \mathrm{c}$. 93].

Поэт и джегуако Ляшин воплощает позитивное начало династии Хаткоесов, в его образе реализуется архетип певца, герой живет в мире звуков и способен воспринимать «светящийся звук» и «звенящий свет». ОН «всегда среди людей, играет свадьбы, сочиняет красивые и добрые слова». Ляшин один из ярко выраженных трансцендентных героев романа, он выступает медиатором между Небом и Землей, миром тонким и физическим.

В завершающей роман новелле «Так и будет» именно душа и сердце Ляшина становятся своеобразным проводником, соединяющим «небеса и землю, Создателя и сотворенное Им» [1, с. 278].

Вечно юный поэт Ляшин и мудрый весельчак Фэнэс - антиподы, одновременно дополняющие друг друга. Имя Фэнэса в перевернутом виде - Сэнэф и означает «Светлое вино», «в его жилах вместо крови течет вино». Фэнэс принимает мир таким, как есть, без вопросов и претензий. Он уверен, что человек рожден для счастья, а не страданий, и видит во всем только положительную сторону.: «Я пьян от этого прекрасного мира, и сам этот мир пьяный от созерцания собственных достоинств и от радости своего существования, я же, выпивая божественный напиток из нектаров его, привожу себя в соответствие с ним.»[1, с.105].

Образы Ляшина и Фэнэса присутствуют практически во всех новеллах, их бесконечные диалоги, продолжающиеся в веках, выражают квинтэссенцию философской мысли романа и актуализируют идею бессмертия, утверждения светлых гуманистических начал. Все эти герои обладают выраженными трансцендентными свойствами. 
Про три-бабушки также говорится, что ее «сердце рассыпано в веках и по всем мирам». Ляшин «видит, чувствует и ощущает тот ирреальный мир, который недоступен восприятию обычных героев, он способен растворяться в нем, находить в нем радость, умиротворенность, «неземное наслаждение». Автор описывает уроки трансценденции, которые герой получает во время сна: «Я стою неподвижно. Растворяюсь во всем... тело мое становится невесомым, как бы не физическим. Стою, смотрю, то, что я назвал своей тенью, стоит, кажется, справа от меня, чуть сзади. Меня всецело захватило какое-то безмерное наслаждение, ощущаемое настолько сильно, что невозможно ни с чем его сравнить...» [1, с. 194].

Напомним, что, «трансцендентный», по Канту, означает - «лежащий по ту сторону опыта», недоступный познанию. Кант называл трансцендентными «вещи в себе» - обозначение того, что хотя и существует независимо от сознания, но абсолютно непознаваемо.

«Трансценденция означает также стать Божественным или богоподобным, выйти за пределы чисто человеческого, - отмечает Маслоу, - Это достижение очень высокого уровня, Божественного или богоподобного. И это часть и потенциал человеческой природы, часть, соответствующая высшим возможностям человека. Трансценденция относится к высшим и в максимальной степени включающим, или холистическим уровням человеческого сознания, поведения и отношения - как к цели, а не средству - к себе, к значимым другим, к людям вообще, к другим видам, к природе и космосу» [2, с. 259]. Трансценденция у Хайдеггера означает открытость бытия. Человеческое сознание трансцендирует, т.е. постоянно выходит за свои собственные пределы, постоянно забегает вперед самого себя, более того, оно, как говорит Хайдеггер, «всегда находится впереди самого себя» [3, с.81].

Приведя себя в состояние гармоничного единства и цельности, человек, как любая цельность, по Шеллингу, сам становится причастным к Абсолюту [4]. Отметим, что в образной системе современного адыгского романа Н.Куек впервые актуализирует героев с трансцендентным сознанием. Герои романа «Вино мертвых» Ляшин, Фэнэс, три-бабушки, постигли универсальную гармонию, они обретает планетарным мышлением. В мифопоэтическом контексте романа «Вино мертвых» присутствует еще один герой, обладающий ярко выраженными трансцендентными свойствами. Это ЭТНОФИАОСОФИЯ АДЫГОВ: ОТ МИФА К АОГОСУ : 
богочеловек Тлепш, прообразом которого является мифологическое божество Тлепш, бог кузнечного ремесла и огня из адыгского пантеона богов.. Содержание новеллы «Он, этот бог, сотворен Хаткоесами», героем которой является Тлепш, восходит к космогоническому мифу об умирающем и воскресающем боге.

А. Шортанов пишет: «В мифологии адыгов Тлепш не только кузнец - он чародей, и лекарь, и философ-мудрец, и бог, именем которого клянутся».[5, с. 98].

Образ богочеловека Тлепша является особенно значимым в семантическом выражении его философской идеи. Онтологическую основу новеллы составляют размышления о сложнейших философских категориях: «что есть истина, время, человек, Бог, что делает человека богоподобным и т. д.» Глубокие философские рефлексии героя о жизни, человеке, вечности бытия перекликаются с эпикурейскими мотивами античных поэтов и философов: «...Ведь ничто не исчезает, только меняется.... Мир вечен, и все, что в нем, тоже вечно... Эта вечность даруется тому, кто живет любовью и «может сотворить в себе бога» [1, с.287]. Можно утверждать, что именно в этом тезисе заложена квинтэссенция философской идеи всего романа, маркируемая также и в названии романа - «Вино мертвых». То есть по мысли автора никто и ничто не исчезает бесследно, что мысли и деяния ушедших в мир иной подобны вину, что со временем лишь крепчает и обретает силу.

В новелле практически нет сюжета в обычном его понимании, ведущей является мысль героя, его поиски истины, его рефлексии о человеке, о том, что приближает его к богам, делает побогоподобным. Философские сентенции героя о четырех основополагающих стихиях бытия глубоки и содержательны, впечатляют масштабностью восприятия и космическим сознанием: «Ты выпьешь глоток воды, и она с того мгновения утвердится в тебе, и все воды в мире будут всегда знать тебя и отождествлять тебя с собой. Вода - во всем и везде»; «Возлюбивший небо, уподобивший свое сердце летучим облакам, вышел за грани видимых человеком пределов».

Завершается новелла тем, что богочеловек Тлепш умирает. «Солнце, которое он носил в себе тысячелетиями, покидает его», ибо закончился еще один, очередной большой «цикл вечности, на уровне галактик и солнечных систем меняющий орбиты планет». Однако его смерть в романе не отрицает идею бессмертия, ибо одновременно 
на земле рождается маленькое человеческое существо - сын Тлепша и Лучезарной Адиюх. В этом мальчике течет кровь нартов, а сердце его, как и у Тлепша, равно всему миру. С этого солнцеподобного мальчика, перенявшего все лучшее у Тлепша, начнется новый цикл жизни для людей. Адиюх и «мать людей» Сатаней будут воспитывать его, бережно взращивая в нем «божественное семя», и рассказывать о том, «что небо бесконечно, просторы беспредельны, и вечность даруется тому, кто может сотворить в себе бога» [1, с. 293]. И мальчик взойдет, как молодое светило, знаменуя начало новой жизни, не знающей конца.

Так авторский миф проводит гуманистическую идею о том, что боги рождаются не на небесах, что они восходят от людей, что они, по мысли автора, «сотворены из вечности, той вечности, которую мы, люди, носим в себе. Они вскормлены нашими надеждами и являются хранителями наших надежд».

Таким образом, проза Н.Куека имеет глубокий философский контекст. Образная система эпики характеризуется наличием героев с трансцендентным сознанием и транслирует идею о том, что человек является многомерным существом, пребывающим одновременно в нескольких мирах. В эпике Н.Куека талантливо, глубоко и многообразно отобразились этноментальные особенности адыгской картины мира.[6].

\section{Литература}

1. Куек, Н.Ю. Вино мертвых / Н.Ю. Куек. - Майкоп, 2002. - 296 с.

2. Маслоу, А.Г. Мотивация и личность / А.Г. Маслоу. - СПб, 1999.

3. M.Heidegger. Platons Lehre von der Wahrheit. 1942, S. 135).

4. Шеллинг, Ф.В. Введение в философию мифологии // Шеллинг Ф.В. Соч. в 2 т. - М., 1989.-T. 2.

5. Шортанов, А.Т. Адыгская мифология / А.Т. Шортанов. - Нальчик: Эльбрус, 1982 $196 \mathrm{c}$.

6. См.: Ханаху Р. А., Цветков О.М. Некоторые типологические характеристики традиционной культуры адыгов (к проблеме ментальности). Научная мысль Кавказа.1996. №2.C.59. 
Мамий Р.Г.

\title{
Человек и его существование в творчестве Аскера Евтыха:
} экзистенциалистические мотивы

\begin{abstract}
Аннотация: В статье автор анализирует произведения А. Евтыха: «История одной женщины», «Баржа», "Бычья кровь», «Разорванная картина», "Разрыв сердиа», автобиографическую повесть "Я - кенгуру» и другие. Отмечено, что экзистенцииальные мотивы, сюжеты часто встречаются в современном литературном процессе, в том числе и в произведениях адыгейских писателей. Это творчество И. Машбаша, П. Кошубаева, Н. Куека, Ю. Чуяко и ряда других, в произведениях которых раскрываются противоречия и сложности жизни.

Ключевые слова: экзистенциальные мотивы, противоречивые формы существования, литература, человек,герои произведений.
\end{abstract}

Экзистенциализм - философское понятие, означающее сложнейшие, противоречивые формы существования. Объектом его познания является человек и мир, осмысливаемые в их отдельности. Это не литературное понятие или течение, но оно тесно связано с эстетикой, искусством, глубоко фундировано в ткань художественной литературы, в поступках и действиях героев произведений.

Экзистенциальными сюжетами мотивирована и современная литература, в том числе и адыгейская. Экзистенциализм в сюжетном контексте наиболее заметен в творчестве И. Машбаша, П. Кошубаева, Н. Куека, Ю. Чуяко и ряда других. В этих произведениях наиболее полнее раскрываются противоречия и сложности жизни, человеческих характеров. Философия существования во всех его субстанциях был заметен еще в первых произведениях А. Евтыха, особенно в книгах «Мой старший брат», «История одной женщины», «След человека», «Глоток родниковой воды».

Не «заглядывая» в сущность и глубину других произведений, последовавших за ними, наглядно представившими, что такое экзистенциализм в литературе, необходимо остановиться на характере Щащи из повести «История одной женщины», которая воплощает в себе некую « философию существования». Этот труднообъяснимый процесс полностью проявлялся в ее жизни, в ее отношениях к мужу Асланбию Хатажукову. В самом начале, когда Щаща узнала о похождениях мужа, она оказалась перед серьезным нравственным выбором. Автор тактично, терпеливо, шаг за шагом раскрывает состояние души молодой женщины. Щаща стала оберегать и семью, и детей, 
и мужа от людской молвы, даже после того, когда он оставил семью и вновь женился. Она ни одного худого слова о Хатажукове никому не говорила. В критические моменты жизни она дважды приютила его. Первый раз в годы войны, когда они с новой женой, гонимые нуждой и войной, как эвакуированные из Ленинграда, приехали в аул.

А когда немцы уже появились в родном ауле, он еле унес ноги к Черному морю, оставив больную жену. А Щаща ухаживала за ней как за родной сестрой. Об этом свидетельствуют письма с огромной благодарностью, написанные ею, Розой, Щаще уже после войны.

Второй раз, тоже после войны, когда Щаща узнала, что Хатажуков находится в Краснодаре, больной, одинокий, забрала его к себе, ухаживала за ним и радовалась тому, что он и его старший друг Паш помирились.

Какие же жизненые интересы у этой героини повести? В реальной жизни все у неё складывается удачно. Дети уже заняли свое место в жизни. Сын Нашхо - главный врач райбольницы. Дочь Карэ с мужем Саниет работает в городской больнице. Все они участники войны, уважаемые люди. Саму Щащу тоже любят окружающие. У нее что, нет самолюбия? Есть, конечно, все это у нее. И все она понимает лучше многих. Во всем этом она убеждает в одном из откровенных ночных разговоров со своим бывшим мужем.

За «Историей одной женщины» последовали другие романы и повести, в которых еще нагляднее и острее проявились экзистенциальные мотивы. Среди них выделяются «Улица во всю ее длину» и «Двери открыты настежь», которые вместе составили дилогию «Шуба из двенадцати овчин». Здесь основные коннотации дествий и поступков героев фундированы в контексте человечности («адыгагъэ»). Интерпретация этой основной адыгской социально-нравственной сути субстанции существования в романе вызвала очень бурные суждения, в которых приняли участие ученые, писатели, общественные деятели. Одни поддержали писателя, другие выступили против, предлагая даже исключить его из Союза писателей и все, что им написано и издано, сжечь.

Главный спор шел вокруг таких героев, как председатель колхоза Хатажук Шалахов, его отец Ибрагим Шалахов, их сын и внук Эдик, завхоз колхоза Нашхо и других носителей зла, против которых выступали многие аульчане, рядовые 
колхозники, жители улицы во всю ее длину. Ибрагим Шалахов, хотя и считал себя непререкаемым авторитетом в ауле, особо не вмешивался в производственные дела сына, хотя и здесь не обходился без наставлений и советов. Для него не важно, что ты сделал что-то, а вот важнее, чтобы ты это сделал первым. И среди неписаных аульских законов слово Ибрагима Шалаха должно быть первым. Он считает себя первым адыгом не только среди своих аульчан, среди мудрых, уважаемых стариков, но и среди всех адыгов. Среди неписаных аульских законов слово его всегда должно быть первым.

Интересен в этом плане образ и его сына Хатажука Шалахова. Он давно считает себя единовластным хозяином колхоза. От отца он перенял одно качество: во что бы то ни стало всегда быть первым. К нему начали привыкать и в этом качестве, считая его крепким мужиком, талантом, самородком. Таково его существование по внешним параметрам. Но психологический срез характера его другой. Он предстает перед нами как человек с тройным стандартом: думает одно, говорит другое, делает третье. Он неглуп, умеет оценивать ситуацию, ловчить и хитрить, приспосабливаться к обстановке, к сложившейся системе власти. Он имеет своих людей на всех этажах руководства. Он ловко расправляется с теми, кто начинает перечить ему. Безнаказанность позволяет ему не различать личное и колхозное. Пользуясь его положением, сын Эдик, брат Каспот, да и некоторые приближенные часто запускают руки в общественное добро.

Конечно, есть люди, особенно из числа молодых, которые противостоят Хатажуку. Это Мос Устоков, Макар Мешлоков, Федор Грибцов, Юра Бешуков и другие. Они своими характерами, мыслями, поступками доставляют ему много неприятностей. Даже молодые девушки, женщины, особенно из числа оставшихся вдовушками, ведут с ним открытый, прямой, иногда и чисто мужской разговор. Раскрывая нравственнопсихологическую основу самой шалаховщины, автор нередко обращается и к взаимоотношениям между её представителями, особенно Ибрагима, Хатажука, Нашхо и ряда других. В них преобладает неприятие, недовольство друг другом, а то и скрытая ненависть. На страхе перед адыгством, перед властью, возможностью привлекать, осудить, посадить, даже невинного человека, они держат весь аул в повиновении.

Это относится в полной мере и к другой не менее важной стороне основной идеи романа, главного конфликтного узла. С ней постоянно сопряжен клубок проблем, 
связанных с духовно-приветственной жизнью адыгейского народа. Речь идет о тысячелетиями выработанном народом своде неписаных норм и законов, который регулировал существование и поведение адыга в любой ситуации - об адыгстве (адыгагъэ). Некоторые растягивают его, как резину, в угоду себе. Важной составной частью романа является раскрытие внутреннего мира, психологии людей, которые, сами протестуя против искажения и нарушения святых заповедей адыгского этикета, из-за ложного понимания адыгагъэ и боязни людской молвы, на виду у всех и молчаливо соглашаются с теми, кто их опошляет.

Еще сложнее и интерснее существование героев повести «Воз белого камня» Moca (по прозвищу Куапце), Хаджи Калокова, Чапа, взятых из гущи революции и гражданской войны. Конечно, здесь идет классовая борьба, соответственно противостояние разных людей. Вначале нельзя было сказать, что у Моса было классовое чутье. Но ему была присуща тяга к свободе, справедливости, желание и готовность защищать человеческое достоинство. Это сталкивает его с такими ярыми противниками надвигающейся новой жизни, как Хануко, Чап, Мышеост, которые вместе и едины, когда хищнически грабят, убивают, попирают элементарные человеческие нормы. Одновременно по-волчьи ненавидят друг друга. В жестокой борьбе с ними погибает Мос.

Всю эту жестокую классовую борьбу автор связывает с конкретной национальной почвой, с особенностями адыгейской деревенской действительности, жизни и быта аульчан, в которых проходит существование Моса. Как и в предыдущем произведении, писатель вновь возвращается к понятиям «адыгагъэ», «адыгэ хабзэ».

Более интересны отношения между Мосом и Хаджи Калоковым. Духовнонравственный мир их намного богаче. Вначале Хаджи покровительствовал Мосу. Их объединяли общность гуманных целей, стремление к равенству и справедливости. Но в выборе путей достижения этих целей их отношений усложнились. Хаджи посчитал, что Мос изменяет мусульманской религии, в рамках которой Калоков стремился решить проблему справедливости. Он придерживался девиза: адыг не должен идти против адыга. А это делает существование адыга очень сложным. Конечно, и Мос тоже до конца не понимал, какой будет новая власть, за которую он борется. Но она не подавляет человечность, адыгагъэ. И Калокову мучительно больно, но под влиянием меняющейся 
действительности, начал преодолевать многие свои сомнения, сам пришел к выводу, что Чап и Мишеост пытаются прикрывать свои грязные и преступные дела этим священным «адыгагъэ» и существуют, хватаясь за него как за спасительную соломинку.

Такие экзистенциальные идеи присутствуют и в других романах А. Евтыха. Наиболее выделяются последние два произведения «Баржа» и «Бычья кровь». И в них объектом идейно-эстетических размышлений автора остается переломная эпоха революции и гражданской войны.

Трудно делить героев Аскера Евтыха на традиционной, положительной основе. Живые, сложные, противоречивые, они взяты из реальной действительности. Они не просто существуют, а делают реальную жизнь. Среди них в названных романах можно выделить Хаджи Исмеля, Ивана Щербину, Бачмиза Аладжа, Хан Гирея, наиболее полно выражающие идейно-философские основы различных слоев общества. Или такие ярко индивидуализированные личности, как Хатрак, Баг, Гармаш, Чубарь, Сутрун и другие. При всей нейтральности к своим героям автор не остается беспристрастным наблюдателем их мыслей, действий, поступков. Он стремится, чтобы каждый герой самовыражался в соответствии со своими убеждениями.

В коротком выступлении обо всем этом не скажешь. Но трудно не подчеркнуть мысль о том, как внутренний мир Хаджи Исмеля, Хана Гирея, Бачмиза Аладжа чаще всего раскрывается через проявления в их действиях, поступках, размышлениях этнокультурного феномена адыгагъэ (адыгства). Гирей и Бачмиз больше всех обращаются к заповедям адыгской мудрости, когда хотят приспособить их к деяниям, часто не совместимым с адыгагъэ. Этим они живо напоминают Шалаховых из романа «Шуба из двенадцати овчин». А для таких людей, как Хаджи Исмель, Хатрак Баг, адыгагъэ - это справедливость, национальная гордость, человечность, честь и совесть, мужское достоинство. Они много не философствуют по поводу адыгагъэ, а выполняют его заповеди, если даже это стоит им жизни. Вспомнить хотя бы, как Хатрака Бага заставляли «ломать шапку», чтобы показать свое почтение высокому начальнику. Но он знал, как почитать заслуженного человека, в этот свод не входит снимать шапку. Шапка для адыга сродни голове. Но то, что он не снял шапку, стоило ему несколько дней тюрьмы. 
А Хан Гирей ловко пользуется этим «адыгагъэ». На слуху, перед людьми, называя себя адыгом, он говорит одно, а делает другое. Перед собравшейся большой группой людей он дает указание освободить из заключения Хаджи Исмеля, не угодного господствующим чинам, объявив, что он делает по просьбе адыгов-стариков, и тут же добавил, что и он адыг и печется о своем народе. И сажает в тачанку, чтобы увезли домой, и пусть, мол, занимается мирным трудом. А следом тайно посылает группу своих головорезов, и его убивают. В двоедушии и лицемерии ему не уступает и старик Аладж, считающий себя предводителем всех старейших адыгов.

Говоря о человечности и справедливости, о чести и совести, стоит прислушаться к червонным казакам Щербинам - Ивану Петровичу и его дяде Илье Савельевичу. Они всегда говорят то, что думают, честны перед другими. Из их уст тоже иногда можно услышать слова «народишко», «народец».

Их понять можно, учитывая их происхождение, хотя эти уменьшительнопренебрежительные слова трудно принять. Но, по убеждению Щербин, выше казачества на Кубани нет и не должно быть. Но эта державная философия не исключает жить в мире, согласии и дружбе с черкесами-адыгами. Щербины уверены, что нет расчета затевать драчку с черкесами, что давно скрестилось все казацкое с черкесским, познали друг друга до самого донышка. Они хорошо знают трагическую историю адыгов, знают, почему когда-то многомиллионный, могущественный народ сегодня приходится называть «народец», «народишко». Иван Щербина - офицер царской армии - доказывает своему другу Виктору Брянцеву, что «адыг величина постоянная, потому что у него, у этого народа, корни глубоко проросли, их и не выжечь, и не вытоптать...»

Конечно, жить, существовать в этом мире не так-то просто. Еще сложнее отразить его в художественных творениях, в эстетических размышлениях. В этом убеждает последняя книга А. Евтыха «Разрыв сердца», в которой размещены две повести - «Разрыв сердца» (Сожженная картина) и «Я - кенгуру». Я писал о ней в своей книге «Вровень с веком» (2001 г.). Но в связи с этой идеей экзистенциализма тянет повторить какие-то мысли. Названные повести больше всего втягивают в философию существования, иногда плотно привязывая еe к национальным (адыгским) особенностям. 
В центре первой повести «Разорванная картина» стоит художник Хамзат Чирашевич Бзегух, его жизнь, творческая судьба. Этим образом Аскер Евтых поднимает важную проблему о месте художника и вообще творческой личности в обществе, где идеологические рамки строго очерчены и свободное творческое мышление чревато непредсказуемыми последствиями; об ответственности в этих условиях, художника за то искусство, представителем, даже национальным лидером которого его считают. Автор показывает, что Хамзат Чирашевич внешне, а вначале и своей внутренней сутью, вписался в эту систему.

К нему внимательны власть предержащие, возвели его в ранг основоположника национальной живописи. Он вхож во все кабинеты, ему отводятся почетные места в президиумах высоких собраний. Слово, жест, взгляд «оттуда» - для него как хлеб и воздух, и он является выразителем идеологии системы. Ему нравится жить в ореоле этой славы.

Автор жестоко и недвусмысленно, многими деталями, репликами выражает свое отношение к такому типу художника и человека, даже и тем, что дал ему фамилию Бзегух, что на родном языке означает доносчик. Тем не менее, он показывает его как изначально драматическую, а в конце повести и трагическую личность. В глубине души и сам Хамзат Чирашевич не мог не чувствовать, что делает не то, что нужно.

Психологическую и нравственную драму этого характера автор связывает и с другой творческой проблемой. Из смутного понимания того, что надо еще что-то делать, начинает вырисовываться неодолимое желание показать красоту женского тела. Но эта идея наталкивается на не менее серьезное препятствие: он чувствует, что обнаженное тело женщины вызовет острое неприятие у адыгского зрителя. Тем не менее, тайно от других, считая, что для себя, начал рисовать своих жен, особенно Масуну. Как художник, он с первого взгляда на нее определил созданные богом и природой ее телесное совершенство, ее красоту и гармонию. Посчитав ее настоящим подарком, божьим даром, он решил, что «должен обессмертить ее, то есть перенести из жизни в холст... и вместе с ее бессмертием обессмертится и его имя». Но можно это механически переносить в адыгейское искусство и выставлять на обозрение адыгскому зрителю? За такими размышлениями последовал трагический конец: Бзегух скончался 
у костра, где сжег сам свою картину с обнаженной Масуной. Во втором произведени А. Евтых ведет лирико-публицистический рассказ о пройденном шестидесятилетнем пути.

Здесь и о матери, и об отце, о родном ауле, о Майкопе, еще о многом другом сказано задушевно, тепло.

Через все повествование проходит одна непрерывная сквозная линия - главная, ради чего, кажется, и написано все это. Она связана с Валентиной Косинской, женой, скончавшейся за год до него. С первого дня знакомства до конца жизни Валя шла рядом с ним, и А. Евтых стремится воссоздать ее образ, черты ее характера, доброту и человечность, заботливое отношение к родным, близким, друзьям, умение находить общий язык со всеми, независимо от возраста и положения человека.

Восхищаясь глубиной и красотой этих чувств, мастерством их передачи, задаешься и другим вопросом: что заставило его на склоне лет, на исходе жизни вот так эмоционально-взволнованно, открыто, оголенно писать об этом глубоко внутреннем, сугубо личном, интимном, относящемся только к ним обоим и выражавшемся в течение всей жизни только намеком, взглядом, настроением, заботой друг о друге, увлечением одним и тем же делом? Это сродни тому же, над чем бился художник Бзегух в «Разорванной картине», хотя автор находится в немного иной нравственно-этической ситуации, чем его герой. Все это заставляет думать о том, что А. Евтых, как и Хамзат, ушел из жизни и унес с собой идею о картине с голой Масуной.

Таковы сложности существования, которые трудно уловить, неодолимы и непонятны с одного захода. А сколько таких ситуаций преподносит нам этот экзистенциализм, эта философия существования?!

Хуако Ф.Н.

\section{Философская мотивация с учетом ее этноракурса в прозе адыгских авторов конца XX века}

Аннотация: Автор анализирует философскую прозу адьгейских писателей: Н. Куека «Черная гора», «Вино мертвых», «Он, этот бог, сотворен Хаткоесами», Ю. Чуяко «Сказание о Железном Волке» и других авторов. Ключевые слова: философичность, экзистенциализм, духовное восприятие.

Так называемой «философией существования» в современном мире считается экзистенциализм, базисными пунктами которого принимаются раздумья Гуссерля и эТНОФИАОСОФИЯ АДЫГОВ: ОТ МИФА К АОГОСУ : 
Кьеркегора, повлиявшие в свое время на формирование профессиональных убеждений философа Сартра. Данная философская установка отвергает традиционный рационализм с опорой на то, что она разграничивает бытие на субъективное и объективное. Имеющуюся в поле зрения индивида реальность традиционная германская мысль преподносила объектом, т.е. некоторой сутью, нуждающейся в постижении. Соответственно рационалистическим тезисам истинная философия обязана источаться из спаянности творящего (субъекта) и творимого (объекта). Подобная цельность олицетворяется в некоторой иррациональной яви (т.е. экзистенции). С тем, чтобы распознать данную субстанцию в себе, индивид обязан попасть в обстановку, уносящую его из мира сего (к примеру, угрожающую жизни). При прохождении таких рисков бытие оказывается для индивида усиленно приближенным. Есть возможность перечислить многочисленную череду разнонациональных философов-экзистенциалистов прежних веков, как то: Н.Бердяев, М.Бубер, Г.Марсель, Э.Камю, А.Хайдеггер, Л.Шестов, К.Ясперс.

Со временем (80-е гг. XX в.) в отечественной прозе усилилось сосредоточение на конкретной личности, роковая участь коей порой являла собой участь несущей ее эры, столь же страдающей и выживающей. Данную линию неоднократно подчеркивали ученые (и пост-, и советские). В их числе - признанный литературовед прошлого века Ю.Кузьменко. Он, по нашему мнению, правильно и точно преподнес специфику недавно возникшего тогда литературного периода, в очередной раз выделив значительный поворот прозаических жанров в сферу философизации. Его правота была отмечена нами еще в одной из монографий 2005 г., когда в ответ на его цитату «Предельная общественная ситуация, ставящая личность в особые, эпические по своему характеру отношения с действительностью, сменилась таким состоянием мира, при котором» «частное и всеобщее соединяются между собой иным, более сложным и опосредованным образом» [1, с.31] мы продолжаем мысль: «Эпицентром художественного изучения становится «частное», проецирующееся на «общественное» и «всеобщее». Отсюда и изменения в характере художественного исследования, усиление в нем аналитического начала» [3, с.88].

Одновременно в течение минувших двадцати лет наиболее востребованной оказалась не только обращенная к человеку, лирическая, но, в частности, и лирико- 
философская проза, когда доктрина духовно-этического предпочтения

реконструируется уже на личностном уровне посредством рассуждений. Обозначаясь имеющейся мировой хронологией, она фиксируется в отдельном, индивидуальном внутреннем мире. Следовательно, ценностные приоритеты таким путем изучаются, варьируются и соотносятся в обширном ракурсе философии, словно общеглобальные [2, с.112]. Иллюстрируют таким образом они теорию ценностных приоритетов, находясь в роли миссии, функцией коей является выявление в индивидууме возможностей гуманности и человеколюбия [3, с.206]. Причем применительно к художественному слову, нота противоположения хорошего и плохого достаточно известна рассматриваемым нами адыгским авторам.

Допустимо твердо провозглашать: фактически любое художественное слово, производимое писателем, порой (частично или целиком) задевало компоненты многосторонней внутренней сферы индивида или формулировало (и освещало) некие моральные нормативы.

Наиболее активным в таком отношении можно считать произведение адыгского автора Юнуса Чуяко «Сказание о Железном Волке» (Майкоп, 1993), стержневой нитью коего выступают проблемы духовного восприятия худа, а также битвы с таковым. Зло здесь особенно выразительно на фоне общенационального добра, в роли которого для любого представителя нации адыгэ хабзэ (то есть этический кодекс адыгов, живущий и действующий на земле столько же, сколько обитает на свете этот давний народ). С подобным духовно-этическим приоритетом («адыгагъэ»), унаследованным адыгами от предков, персонажи неизменно сопоставляют собственные мысли и деяния, и, к тому же, - чужое поведение, обступающее их. Тем не менее, аналогичная философичность в текстах северокавказских авторов конца прошлого века просматривалась только как фон, аккомпанирующий сюжетике. И потому новым словом здесь оказалась отданная духовно-нравственной философичности полная повесть. Имеем в виду изданную в 2001 г. повесть адыгского автора Нальбия Куека «Черная гора» (Майкоп). От первой до последней строки здесь изложение философично. В связи с этим, по нашему мнению, данное произведение среднего жанра является отнюдь не легко-развлекательным. Как подчеркиваем мы по ее поводу в одной из монографий, «Ее философское и образносимволическое выражение где-то даже сложно для читателя. Но зато как глубоки 
мысли, как свежо их отражение в языке повести, как исторически актуальны и в то же время потрясающе современны затрагиваемые в ней вопросы». Восприятие ужасающей катастрофы, накрывшей адыгов более века назад, есть восприятие на генезисе, доставшееся современнику от предков. Оно по сей день болезненно отображается в душе любого земляка, не оставляя его равнодушным. По сей день исходят кровью шрамы, причиненные безжалостным царским захватом земель Черкесии. Именно поэтому настолько активны, одушевленны мучения, терзания персонажей Н.Куека; именно поэтому столь объяснимо и разделяемо читателем их стремление выдворить агрессора. В целом, все герои повести есть образы собирательные, а оттого содержащие немалую семантическую субстанцию с существенным тоном символизма. В философском отношении символизм есть художественный инструмент автора, с помощью коего персонажи несут в собственных типажах признаки, качества, нравы полных наций. Их непосредственные деяния и шаги олицетворяют хронологические факты. Их эмоции, переживания и излияния концентрируют собой копившиеся столетиями мучения непосредственно конкретной народности. Однако кроме общеадыгских проблем автор обозначает и проблематику общечеловеческую. Он погружается в функционирующие всегда и везде духовные ценности и явления: Небо, Дом, Человек, Жизнь, Сердце, Вода, Великий Бог. Философствующего рассказчика интересуют некие детали, обусловленные несокрушимостью, предполагаемой отвлеченностью данных явлений, как то: «Кто может их распознать?», «Кто их видел?», «Каково их лицо?». И потому неким образом подытоживает адыгскую нетрадиционную лирико-философскую прозу среднего жанра книга прозы Н.Куека «Вино мертвых» (Майкоп, 2002). Судя по ходу размышлений философствующего здесь рассказчика, вечно племя человеческое, нетленен воин (нарт - у адыгов), восстанавливающийся и воскрешающийся вследствие каждого (любого по силе) напряжения. Да, порой кончина всесильна, отведать напиток мертвых предстоит любому (даже Великому Богу); однако живое бытие, выстроенное на звуке и свете, более могуче. При этом идентичные мистико-философские напевы достаточно ощутимы в тексте и, одновременно, необходимо подчеркнуть также весьма осязаемое наличие фигуры Великого Бога. К тому же, соблюдая хроникальные, характерные для древней истории адыгов факты, писатель неизменно сосредоточивается на вере языческой. Фактически в любой из 
представленных в книге новелл имеет место описание некоего языческого обычая либо закона.

Однако в новелле «Он, этот бог, сотворен Хаткоесами» Н.Куек выступил еще более активно в направлении жизнелюбивой философии: тут случается появление нарта на свет, а это, в свою очередь, олицетворяет цельное преобладание бытия и его безмерность. Причем подобному воплощению бессмертности жизни успешно способствует авторский слог. Различные коммуникационные орудия героев (обмены репликами, афоризмами) преимущественно сосредоточенные в эпиграфах, есть полноценные перлы писательской думы. Судя по всему, они есть плодотворный итог длительных философских мыслей, фокусирование актуальной мудрости рассказчика совместно с мудростью национальной. Доминирующей же линией всего текста здесь выступает адыгский фольклор со свойственной ему лирической повествовательностью. Таковая прослеживается и в фабулах, и в интригах, и в нравах различных новелл. Знакомство с персонажами уже стартового текста позволяет вернуться к изученным, частым, родным в уже давнем ребячестве текстам («Адыгейские народные сказки»). Тем самым здесь же появляется неодолимое стремление снова схватить их, опять погрузиться в ту чарующую среду, в которой добро преодолевает зло, в которой сильный пол бесстрашный и смелый, а слабый пол, - изящный и преданный. Немалый инструментарий у Н.Куека (в том числе, вопросительная риторика, призывы, лирические знаки, распространенные метафоры и т.д.) однозначно фиксирует отнесенность любого из данных текстов к философски-насыщенному изложению.

Идентичной можно считать орудийную вооруженность и выше упоминавшегося современного адыгского писателя Ю.Чуяко, художественная конструкция текста которого также выстроена по подобию великолепных бус, содержащих чудные перлы. Всякий из подобных камней сверкает, влечет и никакой из их числа не подобен иному. Действительно, отдельная повесть здесь, как и роман в целом, полностью базируется на текстах национального адыгского словотворчества, гармонично заполняющих изложение. Оно ощутимо освещено серебристым лучом национальных изысков легенд, обычаев, преданий, притч, сказаний. Таким образом, ведущимся в тексте изложением, наводненным удивительной гармоничности продуктами устного народного творчества, писатель словно произносит: это та роскошь, каковая до сих пор 
имеется у нас, мы должны оберегать ее, защищать от повсеместного и безжалостного Железного Волка.

Аналогично и у другого современного адыгского писателя Сафера Панеша в повести «Старая рана» (Майкоп, 1994) наличие авторского мнения просматривается в бережно выписываемых им изображениях персонажей, а также - в скрупулезно возводимых им фабульных построениях, в успешно и своевременно употребляемых им речевых витках - средоточиях народной мысли. Соответствующая портретная галерея насыщена здесь адыгскими персонажами, относимыми к многочисленным возрастным и общественным категориям. Следовательно, фабульные изыски базируются здесь на хроникальных сведениях векового масштаба. Самобытным, оригинальным фактическим базисом романной фабулы выступает кадр с похищением малыша (сына Нальмес и Оздемира). Далее все происходящие кадры основаны на нем и обусловлены данным событием. С течением времени пропавший младенец взрослеет в ином доме. Вырастает он, не подозревая о том, что лица, воспринимаемые им в качестве родителей, фактически напрямую виновны в том, что он потерял настоящую семью. Придя к совершеннолетию, выяснив истину о собственных корнях, главный герой не сумел амнистировать новоприобретенную семью, хотя все так же сохранял взращенную к ним любовь. Особенно такая привязанность проявляется здесь на чувствах персонажа к приемному деду, мудрому и философствующему, внесшему с душой в подростка все имеющиеся у него сокровища - багаж знаний и жизненный опыт. Центральной нитью изложения выступает периодически обдумываемая тема нецелесообразности, натянутости стратегии отмщения, наносящей терзания, приговаривающей к плачу и прямых, и косвенных членов действия. В таком семантически выстроенном остове роман «Старая рана» целиком сберегает социальную остроту вплоть до сегодняшнего дня.

При этом жизненная актуальность его уже выбивается за пределы одних лишь семейных выяснений отношений, приобретая охваты государственные и даже, фактически планетарные. Вновь, как и многими веками прежде, в пламени вражды и беспричинной розни бессмысленно погибают юные судьбы, пришедшие в этот мир, бесспорно, с тем, чтобы существовать и созидать, а отнюдь не с тем, чтобы крушить и погибать. 
Судя по вышерассмотренным текстам адыгских писателей, действующий персонаж существенного числа лирико-философских повестей конца 80 - начала 2000х гг. окунается и уходит в размышления о личном бытии, об окружающих, о себе. В пределах всевозможных кадров в произведениях воспроизведены его философские мысли, а также обусловленные таковыми эмоции. К примеру, временная соизмеримость (миг, момент) в роли неизвестного и потому привлекательного для постижения философского явления нередко оказывается предметом обдумывания стержневого героя лирико-философского текста. Иногда такой персонаж робко рассматривает мобильность и параллельную тяготу временной категории, отчаянно размышляет об опоясывающей его взаимной неотделимости часов, дней, годов, а также о сопровождающей их тоске. Подобным образом идентичный философский настрой персонажа путем мастерской психологизации того или иного из рассматриваемых троих писателей сообщается близ расположенному кругу, в том числе элементам домового быта и естественной среды. Подобная изобразительная технология усиленно, порой с обобщением присматривается к обычаям, к передаваемым от предков к потомкам ценностным комплексам и, таким образом, расширяет и усиливает этноличностную доктрину. Данная направленность есть линия усиленного насыщения фабулы и персонажных образов национальной лирикой, фольклором, философией в их сегодняшней трактовке, что наглядно демонстрируют повести целого ряда северокавказских писателей

(3.Толгурова, А.Теппеева, Г.Братова, И.Капаева и прочих).

Следовательно, подобная проза, нередко инициирующая неистовый отголосок критики, одновременно с успешными проявлениями поэтики заключает также полную череду духовно-этнических и философских устройств, несущих в соответствующем писательском методе не просто художественное, но и общественно-значимое содержание.

И, в целом, рассматриваемые нами современные адыгские авторы Н.Куек, Ю.Чуяко, С.Панеш нередко применяют приемы детализации чрезвычайно отвлеченных оборотов, в очередной раз выделяя такую их абстрагированность. Они часто выставляют в своих изложениях аксиоматические проблемы, решения которым не способна найти цивилизованная нация в течение всего ее бытия. К примеру, у Н.Куека: 
«Так чему предназначена жизнь?». Здесь, стараясь найти ответ, писатель провозглашает весьма неприглядный, однако непреклонный в его достоверности вывод: «Живое не должно приходить на землю, его ждут смерть, убийство или страдания, которые не может вынести сердце» [4, с. 48]. Подвести итог текущему статейному изложению можно при помощи данной авторской вопросительной фразы, способной выступить условным бытийным девизом для человечества, обязанного извечно и во веки веков познавать жизненную предназначенность.

\title{
Литература
}

1. Кузьменко Ю. Чтобы передать богатство нашей жизни // Вопр. лит. - 1983. - № 12.

2. См.: Ханаху Р. Северный Кавказ в свете проблем глобализизации культуры//Кавказ и глобализация. 2008.T.2. №2. С.110-113.

3. Хуако Ф.Н. Двадцатый век: эпоха и ее художественное отражение в северокавказской лирической повести. - Майкоп: изд-во МГТУ, 2005.

4. Куек Н. Черная гора. - Майкоп: Адыг. респ. кн. изд-во, 1997. - 182 с.

Схаляхо Д. С.

\section{Этноментальные ориентиры художественных поисков}

в кросс-культурном пространстве XIX и XXI веков

\begin{abstract}
Аннотация: Цель исследования - выявление историко-культурньи истоков художественных образов поэмы М.Ю. Лермонтова «Беглеи» и повести Ю.Г. Чуяко «Последний лай старого выжлеца». Они, свидетельствуя о высокой мере строгости черкесских представлений о боевой чести и достоинстве, раскрывают участь труса через образы Гаруна («Беглец») и Гусарука («Последний лай старого выюлеца»). Индивидуализм героев трактуется ими в морально-философском аспекте, предусматривающем, что славная кончина лучше, чем позорное спасение. Автором статьи отмечается, что и М.Ю. Лермонтов, и Ю.Г. Чуяко смогли сориентироваться на основную ментальную доминанту черкесского общества, на так называемую «культуру стыда», суть которой проявляется в форме общественного мнения, которое для адыгов, по существу, имеет силу закона. Основной вывод, вытекающий из сопоставительного анализа поэмы М.Ю. Лермонтова «Беглеи» и повести Ю.Г. Чуяко «Последний лай старого выжлеиа» состоит в том, что этническая ментальность не исчезает, но она видоизменяется в разные исторические периоды.
\end{abstract}

Ключевые слова: народ, ментальность, мужество, трусость, бесчестие, стыл, моральный выбор, нацииональный характер, конфликт.

Нынешний круглый стол, приурочен к юбилею Руслана Асхадовича Ханаху. В связи с этим в первую очередь следует отметить, что его работы нам, литераторам, ЭТНОФИАОСОФИЯ АДЫГОВ: ОТ МИФА К АОГОСУ : 
очень помогают в выявлении этноментальных основ художественных образов. Особо хочется выделить выпущенную под его научным руководством книгу «Мир культуры адыгов». Она, как и для многих других, стала для меня, можно сказать, настольной книгой. Так что спасибо, Руслан Асхадович, за то, что вы учите нас мыслить философски.

В аспекте обозначенной проблемы круглого стола «Этнофилософия адыгов: от мифа к логосу» особого внимания заслуживает вопрос, касающийся военно-этического комплекса адыгов в дискурсе философии и культурологии. В рамках этой проблематики остановимся на выявлении историко-культурных истоков художественных образов в поэме М.Ю. Лермонтова «Беглец» и повести Ю.Г. Чуяко «Последний лай старого выжлеца» .

Оба автора, и М.Ю. Лермонтов, и Ю.Г. Чуяко, взяли очень сложный момент истории, поставивший героев перед трудным моральным выбором. М.Ю. Лермонтов период Русско-Кавказской войны X1X века, Ю.Г. Чуяко - период Великой Отечественной войны 1941-1945 годов ХХ столетия. Несмотря на более чем столетнюю протяженность расстояния между этими событиями, общее качество, которое объединяет героев М.Ю. Лермонтова и Ю.Г. Чуяко - это трусость. Представляется интересным проследить, как в разные исторические эпохи эти авторы осмысливают в своих произведениях тему мужества и бесчестия.

«Источниками ментальности адыгов могут служить работы тех исследователей, которые понимали необходимость познания особенностей образа жизни горцев, их национального характера и культуры и стремились просветить в этом смысле общественность России - познакомить ее с Кавказом» [1, с. 466-467]. М.Ю. Лермонтов был первым из тех, после А.С. Пушкина, кто поставил как задачу выявление отличительных свойств черкесского национального характера. В своих кавказских произведениях, особенно в поэме «Беглец», он фактически коснулся тех сторон черкесского национального характера, которые объединяются понятиями ментальность и менталитет. Поэтому выявление этноментальных основ и историко-культурных истоков поэмы «Беглец» позволит воспринять не только эстетическое содержание текста поэмы, но и духовный язык наших предков. 
Как известно, каждый народ имеет свой образ мышления, свою систему мировоззрения, которые в значительной степени и определяют направленность его развития. Эта система духовно-нравственных моделей мышления и поведения народа сформировывается в течение тысячелетий в традициях, зависимых от вкусов, представлений и взглядов данного этноса. В этом процессе рождались категории благородного и грубого, красивого и уродливого, героического и трагического. В X1X веке «трагичность исторической судьбы адыгов выразилась в том, - пишет К.Н. Паранук, - что самой востребованной из всех возможных ремесел и профессий оказалась профессия воина. Суровая кочевая жизнь, бесконечные походы, постоянная готовность защитить свою «райскую» землю, которая всегда была предметом вожделения для захватчиков - выпестовали из адыгов искусных воинов и непоколебимых защитников Отечества» [2, с. 69-70]. Поэтому главные ментальные черты адыгов первой половины XIX века оказались ориентированными на традиционные ценности, связанные с культом воинской доблести и сопутствующего ему своеобразного рыцарского духа и рыцарских правил поведения. Народный метод воспитания любви к Отечеству предусматривал, чтобы человек во имя его жертвовал личным счастьем, даже своей жизнью, если обстоятельства этого требовали. Поэтому самым почетным для мужчины считалось совершить героический подвиг и быть впоследствии воспетым народом.

Свидетельств высокой меры строгости адыгских представлений о боевой чести много в описаниях их быта и нравов. Например, Тэбу де Мариньи, свидетельствуя о высокой мере строгости черкесских представлений о боевой чести и достоинстве, писал: «Пылкая любовь к независимости и воинская доблесть, которая не поддается обузданию, делают их грозными для их соседей. Привычные с самого нежного возраста к суровой закалке тела, упражнениям с оружием и лошадью, они признают одну только славу победы над врагом, а стыдом - бегство от врага» [3, с. 26]. И другой исследователь Кавказа, Г. Лопатинский, свидетельствовал: «Я видел весною 1857 г. во время сильной перестрелки на реке Атакуме, как один... бард влез на дерево, откуда он далеко раздающимся голосом воспевал храбрых и называл по имени боязливых. Адыг больше всего на свете боится быть названным трусом в национальных песнях, в этом случае он погиб: ни одна девушка не подаст ему руку. Он становится посмешищем в стране. Таков 
был суровый рыцарский этикет» [4, с. 93]. Именно это чувство позора позволяло воину преодолевать страх на войне. Не смерти должен был бояться настоящий воин, а бесчестия оказаться трусом и предателем. Это и делало смелость общим достоянием всех. В поэме М.Ю. Лермонтова «Беглец» тема мужества осмысливается в этих традиционно-национальных представлениях о долге перед Родиной и своим народом. Это - поэма о рыцарских законах черкесского народа и об участи труса.

Поэма о суровом нравственном долге, гражданской сущности человека на войне. Гарун, герой поэмы, бежит с поля сражения, где сложили свои головы его отец и два брата, защищая свою честь и независимость родного края. Героические действия отца и его сыновей подаются автором в духе народного понимания поведения героев в бою, предпочитающих смерть позорному бегству, ибо гражданское и героическое содержание жизни является для них единственным смыслом и целью человеческого бытия. В отличие от них Гарун своим поступком нарушил установившиеся нравственные приоритеты: перед альтернативой потерять жизнь или потерять честь он предпочел остаться живым. В глазах соплеменников Гарун, позорно струсивший перед опасностью, стал предателем заветов предков. Оставив поле битвы в то время, когда «черкесы гибнут - враг повсюду», пренебрег своими нравственными обязанностями, не отомстил за отца и братьев ради спасения себя одного. Индивидуализм героя здесь трактуется автором в морально-философском аспекте как источник предательства и антинародной сущности жизни.

Но герой не только проигнорировал свои обязанности. М.Ю. Лермонтов пишет: «Гарун забыл свой долг и стыд». Примечательно то, что поэт смог сориентироваться на основную ментальную доминанту черкесского общества, «на так называемую «культуру стыда» (ук1ытэ - Д.С.), суть которой состоит в том, что представитель общества в высшей степени озабочен тем, чтобы не допустить морального осуждения своих действий со стороны общины» [5, с. 14].

Здесь «социальный контроль... проявляется в форме общественного мнения, которое для адыгов по существу имеет силу закона. Известно, что самым страшным для адыгов считается худое слово, худая молва» [6, с. 182]. Именно поэтому общественное мнение у адыгов являлось мощным фактором, регулирующим человеческие взаимоотношения, нравственные принципы жизни, чувство стыда, «в 
котором...доминирует страх, как бы предупреждающий бесчестие, позор» [7, с. 30], становилось механизмом социального контроля, его использование позволяло обществу контролировать поведение молодежи и предотвращать антисоциальные действия и правонарушения. В частности, абхазский ученый В.А. Бигуаа в рамках рассмотрения этических основ художественного образа в литературах абхазо-адыгских народов обращает внимание на то, что « стыд и страх, с точки зрения нравственности, выступают в качестве инструмента морального контроля и проявляются почти во всех категориях адыгагъэ и апсуара. Именно в этом понимании их отсутствие приводит к нравственной деградации человека... С точки зрения этической системы, страх выполняет функцию нравственного регулятора и тесно связан с этической категорией стыда: человек чести, воспитанный в духе адыгагъэ и апсуара, страшится не физической боли или наказания, а общественного, коллективного порицания, позора» [7, с. 30-31]. Именно боязнь осуждения создавала довольно жесткий порядок поведения человека, которому приходилось считаться и даже приспосабливать свои действия к общественной точке зрения. Такой порядок заставлял его жить в боязливой оглядке на людское мнение. Традиционная черкесская система ценностей не позволяла ему быть свободным по отношению к своему роду, семье. Тот, кто не соответствовал традиционно-ценностным установкам и критериям общества, вступал в социальный конфликт со своим народом. Поэма «Беглец» как раз и представляет собой модель такого конфликта. Общество, приверженное традиционным социокультурным ценностям, не может простить Гаруну проявленную им на войне слабость.

Отступничество Гаруна от обусловленных обществом норм поведения лишает его социального статуса, и поэтому он должен быть изгнан.

Вернувшись домой, беглец сначала подходит к сакле умирающего от полученных на поле боя ран Селима и просит убежища. Но, считавшийся до этого случая другом Гаруна, Селим не удостаивает его «ни кровом, ни благословением». Вспомнил Гарун и о любимой девушке. Но его остановила старинная песня, «Месяц плывет и тих, и спокоен», уже встречавшаяся в поэме «Измаил-Бей» под названием «Песня Селима». Ее девушки обычно пели, провожая своих любимых на войну. В ней девушка давала наставление возлюбленному быть мужественным и отважным, чтобы в сражении победить неприятеля. Песня предупреждала, что «Своим изменивший 
Изменой кровавой, Врага не сразивши, Погибнет без славы» [8, с. 553]. Услышав эти слова из уст любимой девушки, герой, предавший чувства провожавшей его возлюбленной, проявив боязливость и несмелость, не решился зайти к ней. Песня возвращает нас к суровой морали черкесов о необходимости жертвовать собой, своей жизнью во имя благополучия Родины. Она, с одной стороны, поднимает тему героического, тему свободы на большую высоту, с другой - выступает как приговор предателю-трусу, изменившему традициям отцов. Суть песни тесно связана с содержанием поэмы. Здесь она направляет, определяет поведение героя.

Последнюю надежду Гарун возлагал на мать. Но его позор падал особенно на мать, воспитавшую труса. Ментальные традиции адыгов с их культом мужества и отваги, подчинившими себе и сознание женщины, породили образ матери, более всего страшащейся родить недостойного сына, сына-труса. Поэтому и она тоже прогнала его, так как предательский поступок героя становится потенциальным источником стыда и для нее:

...гяур лукавый,

Ты умереть не мог со славой.

Так удались, живи один.

Твоим стыдом, беглец свободы,

Не омрачу я стары годы [8, с.551].

Ни дружба, ни любовь, ни родственные связи не могли быть препятствием для безусловного следования народно-общественным установкам, декларирующим права и обязанности каждого отдельного представителя этого этноса. По черкесским обычаям, только смыв свой позор подвигом, герой мог вернуться в лоно традиционных ценностей. Но он оказался неспособным на это, хоть и терпел муки и стыдился своего поведения. Поэтому мнение людей становится мерой поведенческой самооценки героя: Гарун, всеми отвергнутый и изгнанный, пресекает свое постыдное, унизительное бесчестье ударом кинжала, ибо его поведение выходило за рамки черкесской действительности, традиционных норм, определявших мироустройство народа. И имя героя становится для народа синонимом бесславия:

В преданьях вольности остались

Позор и гибель беглеца [8, с. 554]. 
Позорный поступок определил отталкивающее отношение родных к трусу. Сила общественного мнения, обрекшая его на одиночество, была настолько велика, что он предпочел умереть. Потому что, хоть он и понимал, что нарушил нравственноповеденческие нормы своего народа, в то же время не мыслил себя, вне своего этноса. И когда произошел разрыв с ним, тогда и его жизнь потеряла смысл. Этим обусловлено его самоубийство. Насколько бесславным был его поступок, настолько же бесславной оказалась и его смерть - это двойное бесчестье, двойная гибель для героя. Отсюда напрашивается вполне оправданный вывод о невозможности личного благополучия и счастья вне благополучия и счастья всего народа. Так через отрицательный типаж героя-изгоя М.Ю. Лермонтов выразил менталитет адыга-черкеса.

В лице Гаруна «автор с гражданских позиций осуждает и развенчивает в поэме индивидуализм, замыкающий человека в узкие рамки личных интересов и противостоящий общественной морали» [9, с. 133]. А в образах Селима, любимой девушки Гаруна и его матери М.Ю. Лермонтов «утверждает - считает А.Н. Глухов, гражданское и героическое содержание жизни, как единственный высокий смысл и цель человеческого бытия» [9, с. 132].

Тема, поднятая М.Ю. Лермонтовым в поэме «Беглец», приобретает определенную окраску и в повести Ю.Г. Чуяко «Последний лай старого выжлеца». Гусарук, герой повести Ю.Г. Чуяко, как и Гарун в свое время, оставляет войско и возвращается домой. Но в отличие от Гаруна, он, не решаясь пойти домой к родителям, прячется в тракторной бригаде на краю родного аула.

В укрытии Гусарук проводит полгода. Автор демонстрирует, как герой, раз перешедший нравственную планку, постепенно теряет в себе все человеческое. Подчиняясь инстинкту самосохранения, он превращается в убийцу доверившегося ему пса.

Следует отметить, что если в поэме М.Ю. Лермонтова «Беглец» аульчане не могут простить Гаруну проявленную им на войне трусость, то в повести Ю.Г. Чуяко «Последний лай старого выжлеца» отношение односельчан к Гусаруку несколько иное.

Повествование часто перебивается воспоминаниями и нравственными размышлениями персонажей. Из этих воспоминаний узнаем, что до войны Гусарук был неплохим трактористом, был добрым, отзывчивым парнем. В частности, из уст одного ЭТНОФИАОСОФИЯ АДЫГОВ: ОТ МИФА К АОГОСУ : 
из стариков слышим: «Бедный мальчик. Если уж случилось ему дойти до тракторной бригады, что же он не дошел до дому? Пришел бы... повинился бы...» [10, с. 16]. Хоть и в тайне, но останки дезертира жители аула предали земле рядом с могилой недавно похороненного отца.

Голодавшего полгода в своем укрытии и не решавшегося выйти к людям Гусарука пожалели люди. Но это не значит, что они простили ему его позорный поступка. Виноватым голосом другой старожил аула говорит: «Как ни взгляни, Былау предательства не простил бы. Слишком правильный был человек. И то, что похоронили мы их рядом... Он сейчас, наверное, в могиле переворачивается от обиды и негодования: как же так, его, героя и мировой, и гражданской - рядом с трусом?» (10, c. 18).

Герои Ю.Г. Чуяко живут в очень жестокое время. И, обратившись к концепции человека на войне, автор подходит к ней в аспекте решения не только философсконравственных. но и гуманистических проблем. Главный урок трагической повести Юнуса Чуяко - невозможность одномерной оценки человека, даже с позиции высокой морали.

Сопоставительный анализ поэмы М.Ю. Лермонтова «Беглец» и повести Ю.Г. Чуяко «Последний лай старого выжлеца» показал, что, во-первых, этническая ментальность не исчезает. Во-вторых, социокультурная модель адыгского общества вообще с трусостью не совместим генетически. Вместе с тем, как показывает Ю.Г. Чуяко, эта социокультурная модель общества не постоянна, она видоизменяется в разные исторические периоды. Таким образом, глубина исторического мышления Ю.Г. Чуяко проявилась в его стремлении изобразить концепцию человека на войне в потоке изменяющейся действительности. Он, проецируя тему мужества и бесчестия на усложнившуюся ситуацию XX века, демонстрирует творческое отношение к традиции, стремление к её обновлению, оправданное движением времени.

\section{Литература:}

1. Ханаху Р.Г., Цветков О.М., Костылев С.В. От традиционного менталитета к современному // Мир культуры адыгов. - Майкоп: ГУРИПП «Адыгея», 2002. 
2. Паранук К.Н. Мифопоэтика и художественный образ мира в современном адыгском романе. - Майкоп, 2012.

3. Тэбу де Мариньи. Поездки в Черкесию (Перевод с французского языка К.А. Мальбахова). - Нальчик, 2006.

4. Лопатинский Л.Г. СМОМПК. Вып. Х11. - Тбилиси, 1891.

5. Костылев С.В. Менталитет адыгского этноса: проблемы становления и эволюции. Автореферат диссертации канд. филос. наук. - Краснодар, 2003.

6. Ханаху Р. Северный Кавказ в свете проблем глобализизации культуры//Кавказ и глобализация. 2008.T.2. №2. С.110.

7. Бигуаа В.А. Абхазская литература и литература народов Северного Кавказа. Историко-культурный конспект. Диаспора. - M, 2011

8. Лермонтов М.Ю. Беглец. // М.Ю. Лермонтов. Сочинения в двух томах. - М.: «Правда», 1988, т. 1.

9. Глухов А.Н. Эпическая поэзия М.Ю. Лермонтова. - Саратов: Издательство Саратовского университета, 1982.

10. Чуяко Ю.Г. Последний лай старого выжлеца. - Майкоп, 2008.

Цуекъо Н. М.

\title{
Ц1ыф губзыгъэу Къэзанэкъо Джэбагъэ 1ор1уатэм ч1ап1эу щиубытырэр
}

\begin{abstract}
Аннотация: Статья посвящена мудреиу, философу, дипломату и общественному деятелю Жабаги Казаноко, чей авторитет непререкаем вот уже несколько веков. Анализируются философские изречения мудреца, отражающие этическую систему его мышления. Сделана попытка дополнить образ народного мыслителя, определить его место в истории культуры адыгов. Казаноко занимает большое место в устном народном творчестве многих народов Кавказа, и, в частности, адыгов.

Ключевые слова: Жабаги Казаноко, мудрец, философ, фольклор, общество, иенность, человек, князья, сюжеты, традиция
\end{abstract}

Адыгэхэм ц1ыф губзыгъэхэр къахэк1ыгъэх, ахэтых ык1и къахэк1ыщтых. Ц1ыф губзыгъэхэр, бзаш1 охэр, акъылыш 1охэр хэмытмэ лъэпкъыр сыдым ыгъэлъэпкъына!

Адыгэхэм къахэк1ыгъэ ц1ыф губзыгъэхэм ащыщых Цыгъо Теуцожь, Тыу Щэрабыку, Джанчэтэ Къуйнэшъу, Сэлэчэрыекъо Дэгур, Хьаткъокъо 1ащэр, Къэзанэкъо 
Джэбагъ, Мыжей Сахьид, Агънокъо Лащэр ык1и ахэмэ анэпэмык1хэр. Адыгэ бзылъфыгъэхэми зыц1э тарихъым къыхэнэжьыгъэ губзыгъэхэр ахэтыгъэх. Ахэмэ ащыщых Къазий я Хьанифэ, Шэбанэ я Гощэфыжь ык1и нэмык1хэр.

Зигугъу къэтш1ыгъэ ц1ыф губзыгъэхэм шъхьадж ежь ильэуж 1ор1уатэм къыхигъэнагъ. Нахь чыжьэу ты1абэмэ, л1ыхъужъ нарт эпосым хэт Малычыпхъум игубзыгъагъэ непэ къызнэсыгъэми ащыгъупшэрэп Цыгъо Теуцожь, Хьаткъокъо 1ащэм, Къэзанэкъо Джэбагъэ губзыгъагъэу къа1уагъэхэр непи ц1ыфхэм ахэлъ.

Гущы1эм пай, Цыгъо Теуцожь, - «Зэманыжъым щымыгъуазэм зэманык1эм щыгъозэгъуае фэхъут» зи1ок1э демыгъэштэн плъэк1ырэп. Джащ фэд ц1ыф губзыгъэу, ц1ыф 1ушэу Хьаткъокъо 1ащэм (ы1э лъэныкъо и1эжьыгъэп - Н. Цу.) ышнахьык1эу 1эуж къызы1ихыгъэ, псэогъу фэхъунэу щыт пшъашъэр захьык1э къэзымыхьыжьырэм пайк1э, - «Адэ сыдэу сш1ына, $1 э$ зи1эм гу и1эп, гу зи1эм 1э и1эп» зи1ок1э умыгъэш1эгъон плъэк1ырэп. Ежь гушхо, л1ы пхъаш, щтэ ыш1эрэп, ау 1ащэ, ышнахьык1э 1эхэр и1эх. Ары шъхьак1э - къэрабгъэ.

Зыц1э къет1огъэ хъулъфыгъэхэм анэмык1эу зигугъу пш1ынэу мак1эп адыгэ лъэпкъым губзыгъэу, 1ушэу къахэк1ыгъэр, ау тижъхэм жэры1ок1э мыхэр ары анахьэу зикъэбар л1эужхэм къафагъэнагъэр. Сыда зып1ок1э шъыпкъэныгъэр, зэфагъэр, зэфэдэныгъэр обществэм хэлъыным фэбанэщтыгъэх, ягущы1э псыхьэгъагъэ, ц1ыф къызэрык1ом иухъумэк1огъагъэх. Гущы1э псыхьагъэк1э, акъылк1э ялъэпкъ фэлэжьагъэх. Мыхэр зэк1э зы льэгап1эм тезыгъэуцорэр нэфа1оу зэрэщытыгъэхэр ары, шъыпкъэр зэра1ощтыгъэр ары, зафэу зэрэзек1ощтыгъэхэр ары.

Зикъэхъук1э, зи1огъэ-ш1агъэхэр ащымыгъупшъэу, л1эш1эгъу пчъагъэ хъугъэу жэры1о усэхэм зыц1э къыра1оу л1ы губзыгъэу, ц1ыф 1ушэу Къэзанэкъо Джэбагъэ нахь игъэк1отыгъэу тыкъытегущы1эн. Анахьэу хъишъэхэр, къэбархэр бэу зэпхыгъэр Къэзанэкъор ары. Мы л1ым икъэхъук1э тхыдэ1уатэхэм зэк1 п1оми хъунэу зэдрагъаштэу къызэра1отэжьыщтыгъэмк1э янэрэ-ятэрэ зэл1-зэшъузыгъэхэп, ау ч1 ап1эу къызыщыхъугъэмк1э, янэ-ятэхэмк1э ащ яш1ош1хэр зэтек1ых. Джащ фэдэу илъэсэу къызыщыхъугъэмк1и зэнэкъокъухэр щы1эх. А упч1эмк1э ш1эныгъэлэжьхэми я1о зэп. Шэртэнэ Аскэрбий зэри1орэмк1э, Джэбагъэ 1684-рэ илъэсым къэхъугъ. Нало Зауррэ Гъут1э Адамрэ зэральытэрэмк1э 1685-рэ ильэсым къэхъугъ.Михаил Талпэ зэри1орэмк1э зигугъу тш1ырэ л1ы губзыгъэр къызыхъугъэр 1686-рэ илъэсыр ары. 
Хьадэгъэл1э Аскэры зэри1ощтыгъэмк1э Джэбагъ 1684-рэ гъэм къэхъугъ ык1и 1750-рэ илъэсым идунай ыухыгъ.

Лъэпкъэу къызхэк1ыгъэмк1и тхыдэ1уатэхэми ш1эныгъэлэжьхэми я1о зэтефэрэп. Зыхэм оркъхэм къахэк1ыгъэу, ят1онэрэхэм - ятэ л1экъо лъэшым къыхэк1ыгъэу (янэ пщыл1эу), ящэнэрэхэм - янэ Шоджэныкъо пелыуанхэм ашыпхъоу, ятэ а зэшхэм ямылъку лъыплъэрэ к1элэ къызэрык1оу щытыгъэу къа1уатэ. Ащ нахь хьаламэтхэри хъишъэм къе1о. Гущы1эм пай, Джэбагъ л1экъольэш Хьатыхъущэкъомэ япхъурэ, Хьатыхъущэкъомэ адэжь К1ахэм къик1ыгъэ к1элэ хьак1эмрэ къахэк1эу а1 о [1, н. 228]. Хъишъэр ащи блэк1ышъ нахь гъэш1эгъоныхэу Джэбагъы икъэхъук1э къегъэльагъо: къэбэртэе пщымрэ грузин пщы пшъашъэмрэ къахэк1ыгъэу къе1о. Л1ыш1оу, губзыгъэу, дипломатэу Къэзанэкъо Джэбагъ абазинхэм, бэлъкъархэм, къумыкъухэм я 1ор1уатэ къыхафэ. Ахэми яш1ош1 къа1о. Усэхэр фатхы, къэбарыбэ къа1уатэ Джэбагъ ехьыл1агъэу. Джэбагъы изакъоп мыщ фэдэ къэбарыбэрэ хъишъабэрэ зикъэхъук1э къытыгъэ ц1ыфгубзыгъэхэр.

Гущы1эм пайк1э Сэлэчэрыекъо Дэгур къызыщыхъугъэр зэтефыгъэу къа1уатэ. Джащ фэд къызыхэк1ыгъэ лъэпкъыри зэтефыгъэу 1ор1уатэм къеты: зыхэм Дэгур бжъэдыгъу щыщыгъэу а1ощтыгъ. Тхыдэ1уатэу Л1ыхъурэе Гощэмыдэм зэри1ощтыгъэмк1э, ар Шэбэнэхьаблэ пэмычыжьэу Байт1уак1э дэсыгъ. Нэмык1хэм зэра1 орэмк1э, Сэлэчэрыекъор абдзэхагъ: «ежь пщыгъэп, абдзахэми пщы я1агъэп» [2].

Зэк1э тхыдэ1уатэхэм зэра1орэмк1э, Сэлэчэрыекъор Едыджхэм ащыщыгъ. Ц1ыф зэфагъэ. Ащ къыхэк1эу олыеу ц1ыфхэм аштэгъагъ. «Ц1ыф 1ушэу, зафэу зэрэщытым пае ц1ыфымэ олыеу хадзыгъэу щытыгъ: 1оф къин къэхъумэ ц1ыфхэр еупч1ыжьыщтыгъ...хэти нахьи нахь алъытэу щытыгъ» [2]. Къэбархэм къызэра1уатэрэмк1э, ишъхьэгъуси Сэлэчэрыекъор къымыгъэук1ытэжьэу акъыл и1эу, губзыгъэу, ы1они-ыш1эни ыш1эу щытыгъ. Болэтыкъо пщышхом ишъхьэгъусэ акъылынчъэ пщыр, - Сэлэчэрыекъом ышъхьэ къысфахь, - ы1уи зегъак1ом, бзылъфыгъэр акъыл хэлъэу зэрэзек1уагъэм Болэтыкъомрэ Сэлэчэрыекъомрэ азфагу мыхъун къимыхъухьэу зэблищыгъэх.

Непэ къызнэсыгъэми адыгэхэм Сэлэчэрыекъо Дэгум и1огъэ-ш1агъэхэр къахэнэжьыгъэ. Къэзанэкъо Джэбагъы къыфэдгъэзэжьмэ, зэк1э тхыдэ1уатэхэм ащ 
икъэгъотык1э, ц1эу ык1и лъэкъуац1эу фаусыгъэр зэтефэ: «Мэлахъохэм къэзаным (щыуаным) пацэм (мэлыц пц1агъэм) хэлъэу къагъотыгъ.

Ары ц1эрэ л1экъуац1эрэ фэхъугъэхэри.

Къэзанэкъо Джэбагъэ ш1уагъэу фалъэгъурэр бэ: жэбзэ дахэ, жэбзэ къабзэ 1ульыгъ, адыгагъэм хэш1ык1ышхо фыри1агъ ык1и ащ рыпсэущтыгъ, дипломатие ин хэлъыгъ, ифилософскэ гупшысэхэм анахь ч1ып1э ин щызыубытырэр ц1ыфыр ары, зэфэдэныгъэ обществэм хэлъыным фэбанэщтыгъ, иlорэ иш1эрэ зэтетыгъэ. Ш1эныгъэлэжьэу Хьанэхъу Русланы, «Жабаги относится к роду мыслителей, для которых главным в их суждениях, учениях были проблемы человека. Философское кредо мыслителя - человек как наивысшая ценность...» [3, н. 59] - зи1ок1э демыгъэштэн плъэк1ынэп.

Къэзанэкъо Джэбагъэ и1огъэ-ш1агъэхэр непи адыгэхэм бэу ахэлъ. къа1уатэх. Къэзанэкъом акъылэу и1эм къытыгъэ 1ушыгъэхэр непэ гущы1эжък1э алъытэу хъугъэх. Джэбагъы ахэр епхыгъэу, ащ къы1уагъэхэу зэрэщытыр зымыш1эхэрэм л1эш1эгъухэм апсыхьэжьыгъэ гущы1эжъхэу, лъэпкъым зэдыриеу автор ямы1эу къаш1ош1ы. Аш мэхьанэшо и1. Зэрэхъурэмк1э, Джэбагъ ижабзэ дахэ (поэтическэ шъуашэм илъых игущы1э щэрыохэр - (Н. Цу.), къабзэ, ы1орэм к1уач1э и1, мэхьанэшхо и1, купк1 к1оц1ылъ щы1эныгъэм, щы1ак1эм къыгъэуцурэ упч1эмэ яджэуапых, ц1ыфым ип1ун телэжьыхьэх, пц1ыр щагъэзые, шъыпкъэр къаухъумэ.

Джэбагъэ идунэе гъаш1э ыухыгъэу ихьадэгъу къэблагъэ зэхъум, л1ы губзыгъэр ахэк1ыжьмэ ящы1ак1э хъущтым ыгъапэу къэбэртаехэр ыдэжь к1огъагъэхэу, зэрэпсэущтхэмк1э осет къаритынэу елъэ1угъагъэхэу хъишъэм къе1о. Мыщ фэдэ осыетхэр къаритыжьыгъагъэу къа1отэжьы: апэу шъумыу, къышъуаорэм фэшъумыгъэгъу, гъунэгъу дэй благъэ шъумыш1ы, шъуиш1у шъумыубы... Зэжъугъаш1э: зэман къак1уэм щ1экъур - л1ыщ! [4, н. 88 - 89]

Мы л1ы губзыгъэм ы1уагъэм зи хэбдзыни хэплъхьани плъэк1ынэп. Адыгэхэм a1o: «1ом 1о къек1ы, ш1эм ш1э къек1ы», «Узаорэр - къыоожьыщт». Джащ дак1оу «Къыуаорэм еожь, къыуатэрэм етэжь», - ы1ощтыгъэ тильэпкъы. «Къыуаорэм уемыожьмэ, 1 э уи1 1оу ыш1эрэп», - e1о гущы1эжъым.

«Гъунэгъу дэй благъэ шъумыш1ы» зыра1уагъэри шъыпкъэ. «Шхъадж игъунэгъу игъундж». - a1o адыгэхэм. Гъунэгъу дэир пыщэгъу зыпш1ык1э ащ ышъок1э 
къыоплъых. Ар ащ и1оф. «Шъуиш1у шъумыубы», - къари1ожьыгъ къэбэртаехэм Джэбагъэ. Ари шъыпкъэ. «Уиш1у ц1ыфыр, пшъхьэ фэбгъэдагъэр, бгъэныбджэгъурэр уубымэ - ащыгум о зыоубыжьы. Шъыпкъэп п1он плъэк1ынэп а осетыри. «Зэманэу къак1орэм хэзагъэрэр л1ы» зыфи1уагъэми шъыпкъэ хэлъ.

Непэ гущы1эжъэу алъытэхэу Къэзанэкъо Джэбагъэ игубзыгъагъэ къытыгъэу щы1эр мак1эп. Ащ мыхэр ащыщых: «Нахьыбэмэ аш1эрэр хабзэ», «Нахьыбэмэ а1орэр шъыпкъэ», «Уишъуз уипыин нахьи зэрэчылэу уерэпый», «Чылэмэ агъэпыутыгъэ л1ыр шъузым къыдищыжьын, ау шъузым ыгъэпыутыгъэ л1ыр хэты къыдещыжьи?!», «Бэ ептымэ фэмышхэу, мак1э ептымэ зигъэгусэу. Щысэу шъхьаукъэу, гъолъмэ мычъешъурэр жъы хъугъэ», «Уибынырэ (уик1алэхэмрэ) уишъузырэ зы заш1эу, о жъым уфак1о ухъугъэу, лые узахэхъуахьк1э ащ нахьи щэ къыптефэмэ къэпштэн», «Мэлак1э ул1эу пшхырэр 1эш1у» «1ушыр си1эпы1эгъу, делэм сэ сыри1эпы1эгъу», «Чыр ц1ынэзэ къэмыуфэмэ, пчэгъу зыхъук1э къыпфэуфэжьыщтэп».

Мы ушъыйхэри зыехэр Джэбагъ ары: «Егупшыси псалъэ, зыплъыхьи т1ыс» «Уидэгъу ущымытхъу, уидэй умыгъэбылъ», «Л1ыш1у шъумыубы»ык1и анэмык1ыхэр. Зэк1э Къэзанэкъом и1огъэ-ш1агъэхэм осэшхо я1, купк1 ак1оц1ылъ. Зэфэхьысыжьхэр озыгъэш1ырэ, ухэзыгъэгупшысыхьэрэ 1огъэ-ш1агъэх.

Къэзанэкъо Джэбагъэ къызыхъугъэр илъэс шъищырэ щэк1ырэ щырэ хъугъэ, ау ащ и1огъэ-ш1агъэхэр непи ащыгупшэрэп.

Уасэу фаш1ырэми къыщык1эрэп. Ащ ишыхьат Нало Зауры к1эух гущы1эу научнэ конференциеу Джэбагъ къызыхъугъэр илъэс шъищ зэрэхъурэм ипэгъок1эу Нальчик 1987-рэ илъэсым щы1агъэм къыщиш1ыгъагъэр. Мары ащ ы1огъагъэр: «Как говорил славный мудрец, любое дело настолько велико, насколько его поднимешь. А Жабаги настолько велик, что честная работа в области казаноковедения может возвысить любого исследователя» [5, н. 138].

Ары зигугъу тш1ырэ л1ы 1ушыр, л1ы губзыгъэр ц1ыф льэпкъ зэфэшъхьафыбэу Кавказым щыпсэухэрэм яек1э зык1алъытэрэр, я1ор1отэ ш1агъохэм ч1ып1эшхо зык1ащиубытырэр. Шъыпкъэ ш1эныгъэлэжьэу В.П. Меремкуловым ытхырэр: «Все эти сюжеты традиционны для устного творчества народов нашего региона» [6, н. 134]. 


\title{
Литература:
}

1. Жабаги Казаноко. - Нальчик: Издательский центр «Эль-фа», 2001.

2. Ф. 1. П. 53. Д. 77.

3. Р.А. Ханаху. Мудрец и философ Ж. Казаноко // Философия и социология в

Республике Адыгея6 Научно-информационный сборник № 1. - Майкоп, 1994.

4. Къэзанокъо Жабагъы. - Къэбэрдей тхылъ тедзап1э - Налшык, 1956.

5. Жабаги Казаноко (300 лет) Материалы региональной научной конференции (30 - 31 октября 1985 года). - Нальчик, 1987.

6. Материалы региональной национальной конференции $(30-31$ октября 1985 г.) Нальчик, 1987.

Тугов Р.Г.

\section{Специфика философско-гуманистического учения \\ Тембота Керашева о высоконравственном человеке}

\begin{abstract}
Аннотация: Данная статья посвящена философско-гуманистическому
мировоззрению T. Керашева, в основе которого лежит идея гуманистического антропочентризма. Данная идея уже была заложена в «несказочной прозе» адыгского фольклора. Специфика философско-гуманистического учения T. Керашева заключается в том, что в нем отсутствует современная тенденция отождествления, взаимного подчинения или взаимного противопоставления морально-этических понятий адьгской философии и этики: «человечность (иІьфыыгъэ)» и «адыгственность (адыгагъэ)». Их можно и нужно соединять, но нельзя их отождествлять. Их можно и нужно разделять, но нельзя их противопоставлять друг другу.
\end{abstract}

Ключевые слова: нравственность и безнравственность, человечность $u$ бесчеловечность, человечная адыгственность, нравственные качества и нравственные требования.

T. Керашев был не только советским адыгским писателем и основателем национальной письменности и литературы, но и глубоким мыслителем и сторонником философско-гуманистического понимания человека и личности. О его жизни и литературном творчестве написано и издано множество научных статей, диссертаций, монографий и книг. Однако, на наш взгляд, малоизученными остаются философскогуманистические статьи и заметки Т. Керашева как мыслителя, гуманиста и моралиста. Целью нашего исследования является выявление специфики философско- 
гуманистического учения Т. Керашева о возвышенном и высоконравственном человеке, которому противостоял низменный и безнравственный человек в адыгском обществе.

Специфика философско-гуманистического учения Т. Керашева о человечной нравственности заключается в том, что в нем отсутствует современная тенденция отождествления, взаимного подчинения или взаимного противопоставления моральноэтических понятий адыгской этики и культуры: «человечность (цІыфыгъэ)» и «адыгственность (адыгагъэ)». Свое философско-гуманистическое мировоззрение Т. Керашев раскрывает в тех немногих, но в глубокомысленных статьях и заметках. Некоторая интересующая нас часть опубликованных статей Т. Керашева: Керашев Т. Непреклонно стремление народов к миру. В защиту мира и счастья. // Дружба. - 1951. - № 3. Керашев Т. Сердцем к сердцу: заметки писателя // Адыгейская правда. - 1982. 30 июля. Керашев Т. Слово об адыгах (черкесах) // Литературная Адыгея. - 2002. - № 3. Керашев Т. У истоков нашего печатного слова // Литературная Адыгея. - 2002 - №3. Керашев Т. Адыгейский фольклор: статья // Литературная Адыгея. - 2012 - №3. КІэрэщэ Т. Гур гум пэблагъэу // Зэкъошныгъ. - 1997. - № 3 (149). КІэрэщэ Т. Хэта мысэр? // Адыгэ макъ. - 2002 - ШышъхьаІум (авг.) и 13. КІэрэщэ Т. ЦІыфыр цІыфын фае //Адыгэ макъ - 2010 - Мэзаем (февраль) и 6. Особое внимание мы уделили газетной заметке «Сердцем к сердцу» - «Гур гум пэблагъэу» и публикации «ЦІыфыр цІыфын фае» («Человек должен быть человеком (человечным»)

По убеждению керашеведа, профессора У. Панеша, Т. Керашев «безусловно, оставил богатое творческое наследие. Автор первого рассказа, первого романа в адыгской культуре, основоположник национальной литературы...И все же не покидает ощущение того, что настоящее место Тембота Керашева в развитии национальной культуры не обозначено, что некоторые грани его таланта все еще остаются не освещенными и что о главном, определяющем, может быть, только предстоит сказать» [1. с. 3]. Он считает, что гуманистическое мировоззрение Т. Керашева, особенно его идея о «самоценном значении отдельного человека», углубила концепцию человека и привела к переоценке природы творчества». В художественных произведениях Т. Керашева общечеловеческие ценности воплощены и выражены как национальные ценности. Герои Т. Керашева соблюдают общечеловеческие императивы 
«человечности» как свои общеадыгские требования «адыгской человечности», выражают эти требования через свой национальный (родной) язык, костюм и вкус.

Общечеловеческие, но выраженные как национальные, нравственные императивы в современном многонациональном и многоконфессиональном российском обществе «сегодня заслуживают особого внимания, переосмысления и тщательного изучения...А это непросто в условиях кризиса, отсутствия национальной идеи и устоявшихся критериев, в том числе в сфере искусства и литературы» [1. с. 3 ].

По мнению самого Т. Керашева, в недрах самобытной духовной культуры адыгов «созданы прекрасные образцы устного народного творчества - нартский эпос, замечательные песни, сказки и сказания, пронизанные гуманистическим пафосом и оптимизмом. Роль фольклора в формировании нравственного самосознания народа очень велика» [2. с. 67]. Таким образом, в основе философско-гуманистического мировоззрения Т. Керашева лежит новоевропейская идея гуманистического антропоцентризма, которая ставит человека в центр всего мироздания и объявляет человеческую личность величайшей ценностью и, безусловно, заслуживающим человеческого счастья уже в этом мире. Проблема соотношения философсконравственных понятий «адыгственность» и «человечность» стала и остается объектом исследования современных российских адыгских философов и социологов. Наряду с общеадыгским морально-этическим феноменом адыгственность (адыгагъэ), который определяется как совокупность принципов и норм адыгской этики, выделяется главное общепризнанное нравственное требование адыгской этики - человечность (цІыфыгъэ).

Философско-этическое наследие древних адыгов было подробно исследовано современными российскими учеными на базе отдела философии и социологии Адыгейского республиканского института гуманитарных исследований им. Т.М. Керашева. Еще в 2002 году была издана первая коллективная монография «Мир культуры адыгов», составителем и научным редактором которой выступил российский адыгский философ и социолог Р.А. Ханаху. В течение пяти лет проводились философско-социологические исследования понимания и толкования общепризнанного морально-этического феномена «адыгственность (адыгагъэ)» в современном сознании и бытии адыгов. Результатом подобного изучения стало новое коллективное заключение философов, социологов, культурологов и других участников исследования, 
которые и сформулировали следующее определение данного феномена: «адыгагъэ (адыгственность) - это традиционная базовая система морально-нравственных и этических норм, соотнесенная с общечеловеческими (гуманистическими) ценностями и ориентированная на них») [3. с. 177-184]. Абсолютное число опрошенных респондентов связывают данное понятие с нравственным понятием «цыфыгъэ (человечность)». В массовом сознании адыгского общества «адыгагъэ (адыгственность)» и «цІыфыгъэ (человечность)» мыслятся почти как синонимы»») [3. с. 177-184]. Если речь идет о безнравственном человеке, в адыгском обществе говорят: «Адыгагъи, цІыфыгъи хэлъэп» - «Нет в нем ни адыгственности, ни человечности». О высоконравственном человеке говорят: «ЦІыфыгъи, адыгагъи хэлъ» - «Есть в нем и человечность, и адыгственность». Таким образом, по убеждению Р.А. Ханаху, выявленное в результате опроса мнение респондентов о том, что «адыгагъэ (адыгственность)» и «цІыфыгъэ (человечность) близки или совпадают по содержанию, имеет принципиальное значение». [4, с.6] Подобный результат опроса респондентов, несомненно, побуждает нас к новому философскому осмыслению или переосмыслению духовно-нравственных императивов адыгской этики и культуры в целом.

Б.Х. Бгажноков считает, что многие исследователи повсеместно выделяют нравственное качество человечность (цІыфыгъэ) «как самую первую заповедь и характерную черту адыгства» [4. с. 160-177]. Профессор А. Ю. Шадже поддерживает профессора А. А. Хагурова, утверждающего, что «адыгство означает искусство быть адыгом, искусство быть человеком» [5. с. 78].

Особенность керашевского понимания человечной нравственности заключается в том, что Т. Керашев рассматривает нравственные понятия «человечность» и «адыгственность» в отношении пересечения. Человечность может быть адыгской и неадыгской, адыгственность может быть человечной и нечеловечной. Т. Керашев в своих произведениях и рассуждениях пытается убедить нас в том, что данные нравственные категории можно и нужно рассматривать как категории взаимосвязанные и взаимовлияющие в адыгской этике и культуре в целом. Их можно и нужно соединять, но нельзя их отождествлять или рассматривать в отношениях взаимоподчинения. Их можно и нужно разделять, но нельзя их противопоставлять друг другу. 
По убеждению Т. Керашева, человека делает прекрасным в обществе его образ и качество нравственной жизни. Человеческие мысли, намерения и переживания не были постоянными на протяжении всей человеческой истории: они менялись. В разное время разные народы имели разное понимание «прекрасного» и «безобразного», «хорошего» и «плохого» Но независимо от различия идеи, нравов и вкусов все народы как представители человечества стремились к общей для всех людей человечности. Рассуждая о национальных ценностях адыгского общества, интернационалист $\mathrm{T}$. Керашев не противопоставляет нравственные ценности разных народов, а, наоборот, ищет и находит в них общечеловеческие умственные понятия, нравственные требования и художественные представления, общепризнанные почти во всех мировых культурах и цивилизациях.

В своей интернациональной заметке «Сердцем к сердцу» («Гур гум пэблагъэу»). T. Керашев пишет об общечеловеческом стремлении российского и адыгского народа: «Несмотря на различие национальных нравов и образа жизни двух народов, их человеческие сущностные качества и намерения были схожи, и оба народа одинаково стремились к общечеловеческому миру и согласию, к общечеловеческой солидарности и справедливости» [6. с. 2].

Нравственными требованиями адыгской человечности Т. Керашев считает определённые правила адыгской этики и нормы адыгского этикета. Т. Керашев выделяет главные качества высоконравственного человека, которые возвышали и украшали каждого человечного адыга и все человечное адыгство в целом. Он пишет о таких общеадыгских человечных качествах и требованиях, как «почтительность, учтивость, рассудительность» («цІыфыр анахь зыгъэдахэрэр - Іэдэб хэлъыныр, цІыфым гульытэ афыриІэу, Іушэу зекІоныр ары») [7. с. 2-3]. Более того, главное нравственное качество «человечность» («цІыфыгъэ») у адыгов, по Т. Керашеву, означает «обладать мужественностью и сострадательностью, учтивостью и справедливостью» («цІыфыгъэм адыгэмэ боу бэ къырагъэкІыщтыгъэ: лІыгъи, Іэдэби, гукІэгъуи, зэфагъи») [7. c. 2-3].

Таким образом, к главным нравственным качествам и требованиям адыгской человечности Т. Керашев относит почтительность и учтивость, разумность и мужественность, сострадательность и справедливость. Тут же он приводит как 
человечные правила и нормы адыгской этики и адыгского этикета, так и те тенденции (излишества), которые могут, по убеждению Т. Керашева, исказить человечную адыгственность, превращая ее в бесчеловечную и жестокую догму требований.

Почтительность («лъытэныгъ») и учтивость («Іэдэбыныгъ»). Подлинный человек проявляет почтительность по отношению ко всем людям в человеческом обществе.

Если человек не знает и не почитает свое человеческое достоинство, то он и не будет знать, как почитать достоинство другого человека.

По убеждению Т. Керашева, быть почтительным значит уважать и почитать другого человека как самого себя, ибо «тот, кто не уважает другого человека, тот не уважает и самого себя» («цІыфыр зымылъытэрэм ежъ ышъхьи ылъытэжьырэп») [7. с. 23]. Безусловно, пишет Т. Керашев, что «одним из прекрасных правил адыгского этикета является правило уступать место достойному человеку («адыгэмэ а тІысыпІэ фэхь Іофыр анахь хабзэ дахэу ахэлъыгъэхэм ащыщыгъ»). «Правило для младшего уступать место старшему - это человечно. Правило стоять младшему перед старшим, когда нет места для всех, - это человечно («ныбжьыкІэм тІысыпэр нахьыжъым фигъэкІотэныр цІыфыгъ. ЧІыпІэ щымыІэмэ, нахьыкІэр нахьыжъымэ ашъхьащытыныри - цІыфыгъ») [7. c. 2-3].

Но со временем нравственные требования адыгской человечности были засорены ненужными жестокими ограничениями и безобразными излишествами. Например, было допущено бесчеловечное требование как «возможное, но несправедливое жестокое требование стоять младшим перед уже сидящими старшими при наличии свободных мест» («джащ фэд нахьыжъхэр зытІысыхэ уж, тІысыпІэ лые щыІэ пэтзэ, нахьыкІэхэр ахэм ашъхьащытмэ мыхъунэу») [7. с. 2-3]

В современном обществе женщины уже стали более независимы и более значимы. Критерием человечности и воспитанности человека, по мнению самого Т. Керашева, является его отношение к женщине. Но и в наше время в современном обществе остаются элементы и тенденции жестокого отношения к женщине.

Т. Керашев убежден, что человечное отношение к женщине требует нам относиться к женщине как «к прародительнице и матери всего человеческого рода....., поэтому мы должны почитать всех женщин мира как почитаем свою родную мать, 
облегчать им трудности нашей жизни» («хэти щымыгъупшэ мыхъущтыр бзылъфыгъэм цІыфлъэпкъыр къызэрэтекІыгъэр, цІыфлъэпкъым янэу зэрэщытыр ары. Ащ елъытыгъэкІэ, бзылъфыгъэм икъин нахь псынкІэ зэрэфэпшІын, уянэ лъытэу фыуиІэщтыр бзылъфыгъэ пстэуми афиуІэн зэрэфаер ары»). Но некоторыми бесчеловечными членами адыгского общества было придумано требование, а именно «жестокое и несправедливое по отношению к женщинам требование, запрещающее вообще садиться женщинам там, где уже сидят мужчины» («итІани хъулъфыгъэхэм апашъхьэ бзылъфыгъэр щытІысыхэ мыхъуныр - ар акъылкІэ сыдэущтэу къебгъэкІун плъэкІына!») [7. с. 2-3].

Сострадательность («гукІэгъу») и справедливость («зэфагъэ»). Прекрасные правила адыгского гостеприимства иногда искажаются необязательными излишествами. Например, утверждает Т. Керашев: «встретить гостя с открытым сердцем и ясными глазами есть человечность, однако и гость, замечающий и учитывающий жизненное и бытовое положение хозяина, поступает человечно по отношению к принимающей семье», («хьакІэм нэгуихыгъэу упэгъокІыныр, нэгуихыгъэу пхьакІэныр, удэзекІоныр, цІыфыгъэшхоу анахь тищыкІагъэмэ ащыщ. Ау хьэкІапІэ кІорэм гулъытэ иІэн, зыдакІорэм хьылъэ фэхъун-фэмыхъуныр, иІоф зытетыр, исабыйхэм щылъыпІэу яІэр зыфэдэм егупшысэныр - ари цІыфыгъэм анахь ищыкІагъэхэм ащыщышъ, пщыгъупшэн фаеп») [7. с. 2-3]; «встретить злых нарушителей нравственных законов, не признающих и не почитающих старших и женщин, портящих жизнь всего населения в поселении, и промолчать, и пройти мимо такого безобразия есть бесчеловечный поступок, не имеющий никакого отношения к человечности» («бзаджэу, зышъэ икІыгъэу, хабзи, нахьыжъъи, бзылъфыгъи къизымыдзэжьхэу, щыІакІэр зыушІоеу чылэм къыдэуцохэрэм защыбдзыеу, ягугъу умышІэу уаблэкІыныр - ар цІыфыгъэм зыкІи гуахьэрэп») [7. с. 2-3].

Подобные несправедливые требования в адыгской культуре сохраняются как искаженные временем и условиями жестокие правила. Нравственные требования подлинной адыгской человечности не требуют от человека непосильных излишеств, она требует соблюдать во всем меру, ибо являются разумными, прекрасными и справедливыми. 
Таким образом, Т. Керашев убежден в том, что необходимо обучать и воспитывать молодое поколение высоконравственным человечным требованиям адыгственности в противоположность безнравственным бесчеловечным требованиям адыгственности в современном обществе. Самым важным и необходимым занятием писателей и мыслителей должно стать формирование, возвышение и укрепление высоконравственной человечности и адыгственности, возвышенных и прекрасных человечных нравов и отношений в современном адыгском обществе.

\section{Литература:}

1. Панеш У.М. Перечитывая Тембота Керашева... К 111-летию со дня рождения // Советская Адыгея. - 2013 - 17 августа.

2. Керашев Т. Адыгейский фольклор: статья // Литературная Адыгея. - 2012 - №3.

3. Ханаху Р.А. Феномен адыгагъэ: к постановке исследовательской проблемы//Философия и социология в Республике Адыгея. Майкоп.1994. С.6-7.

4. Ханаху Р.А. Морально-этический феномен «адыгагъэ»- основа народной культуры // Мир культуры адыгов. Майкоп, 2002.

5. Бгажноков Б.Х. Адыгская этика как соционормативная система // Мир культуры адыгов. Майкоп, 2002.

6. Шадже А.Ю. Национальные ценности и человек // Майкоп, 1996.

7. Керашев Т. Сердцем к сердцу: заметки писателя // Адыгейская правда. - 1982. 30 июля; КІэрэщэ Т. Гур гум пэблагъэу // Зэкъошныгъ. - 1997. - № 3

8. КІэрэщэ Т. ЦІыфыр цІыфын фае //Адыгэ макъ - 2010 - Мэзаем (февраль) и 6. 


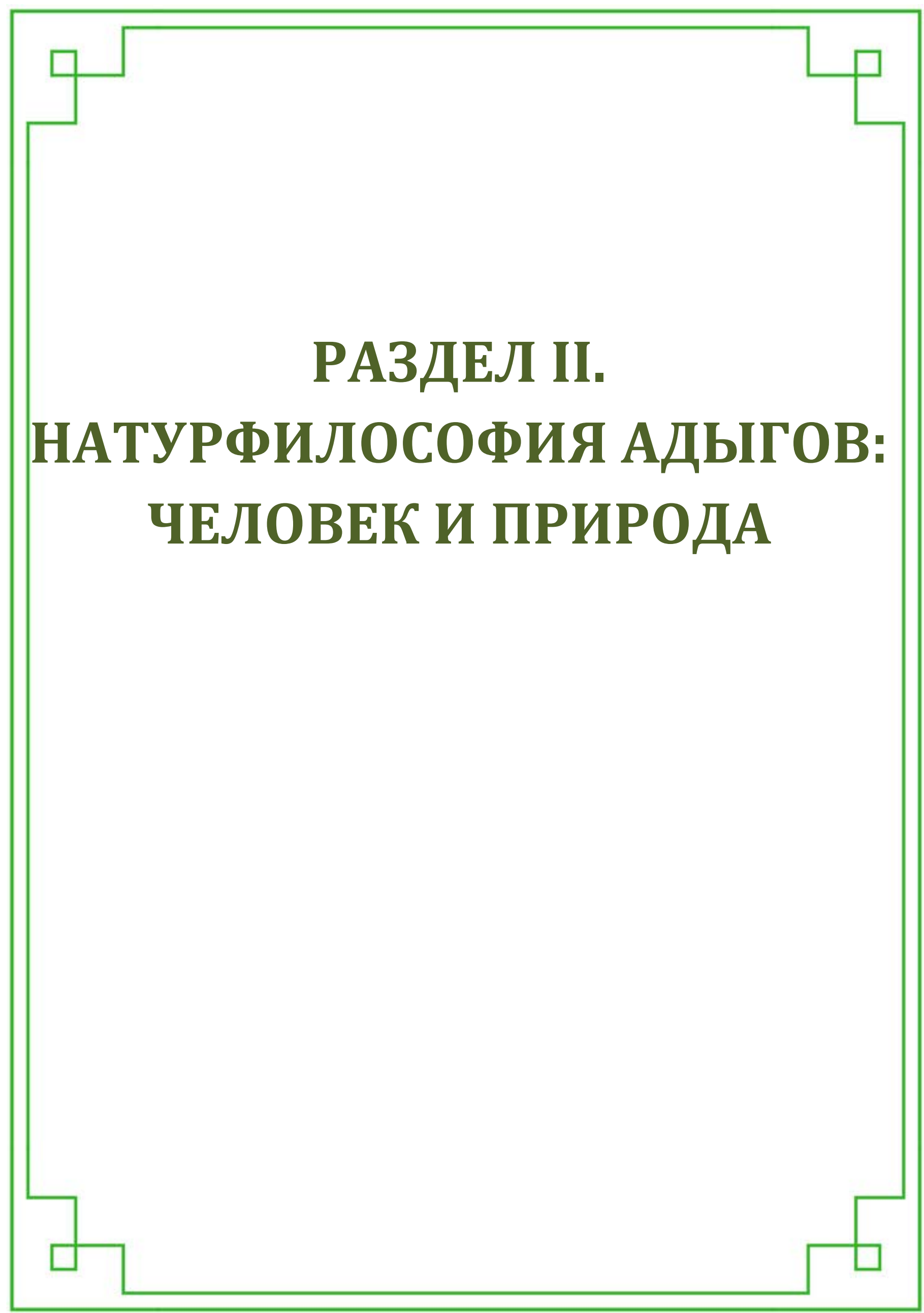




\title{
Тхагапсова Г.Г.
}

\section{Натурфилософские взгляды в народной медицине адыгов}

\begin{abstract}
Аннотация: Статья посвящена анализу натурфилософских взглядов в этномедицине адыгов. Проводя параллели между подходами к врачеванию в народной медицине адыгов (преемников меотской культуры) и древнегреческой медицины, описанные в Гиппократовом сборнике, автор находит общие подходы в понимании болезни и приниципах их лечения

Ключевые слова: натурфилософия, Древняя Греция, меоты, здоровье, душа, вода, воздух, анатомия, хирургия, лечение
\end{abstract}

Натурфилософские идеи рационального постижения мира, позволяющие понять все сущее и все предметы в их единстве и в многообразии форм как новый этап эволюции мировоззрения и духовного развития человека, появились почти одновременно в Индии, Китае, и Древней Греции. Наибольшего развития они достигли в Древней Греции в VI - IV веках до нашей эры, где создались особые условия для развития общества, экономики и культуры. Это, во-первых, период расцвета древнегреческого рабовладельческого общества, создавшего условия для возникновения и развития нового философского направления. Во-вторых, великая греческая колонизация, оказавшая огромное влияние на развитие древнегреческого общества, особенно в экономической и духовной сфере. Благодаря колонизационным процессам культура Древней Греции впитала в себя культуру множества народов, которые проживали в Средиземноморско-Черноморском бассейне. Расширение связей и контактов с другими народами, открытие ранее незнакомых грекам обычаев, нравов и верований не могли не наводить на мысль об относительности их собственных социальных и политических установлений. Дух свободной политической дискуссии в сочетании с уважением к закону, к порядку и, самое главное, к личности, царивший в большинстве городов-государств (полисов), способствовал открытости древнегреческого общества для всего нового, создавал все условия для развития рационалистической направленности философской мысли [1].

Как особый субрегион греческой цивилизации ученые рассматривают северовосточную периферию Черноморского бассейна. Именно здесь проходит Западная оконечность степного пояса Евразии и начинается отличная от греческой природно- 
географическая зона с местными племенами, имеющими совершенно иной тип культуры. Активная колонизация греками северо-восточного Причерноморья, возникновение Боспорского царства, имевшего тесные связи с меотскими племенами синдов, стимулировали развитие торговых и культурных связей, способствовали развитию инициативы, предприимчивости, энергичности, рациональности, направленные, прежде всего, на познание бытия как такового. Как отмечает О.В. Галут: «Тесные межэтнические контакты с античным миром способствовали социальноэкономическому развитию племен Прикубанья, проникновению в их среду многих достижений древнегреческой культуры: развитию ремесел - гончарного, ювелирного, оружейного, рыбного промысла, сельского хозяйства, расцвета искусства» [2].

Сегодня имеется достаточно исследований, основанных на археологических, исторических, лингвистических материалах, позволяющих говорить, что преемниками меотской культуры на Северо-Западном Кавказе являются адыги [3]. В данной статье мы хотели рассмотреть натурфилософские представления адыгов, отраженные в народной медицине адыгов в их связи с древнегреческими раннефилософскими взглядами.

В развитии натурфилософии выделяется ряд этапов. Свое начало история натурфилософии берет именно в Греческой колонии и связана с именем Фалеса из Милета. Фалес вводит концепцию первоэлемента в качестве универсальной теории, утверждая, что все вещи произошли из воды. Душа, по его мнению, это особое состояние воды.

То есть душа наделяется субстратом, общим для всего мира, рассматривается как природное явление. Для античной натурфилософии также важно осознание неотделимости души от тела. Вода в понимании Фалеса - это "физис" (жидкое состояние вещества). Другой представитель Милетской школы, Анаксимен, считал первоматерией воздух, который является бесконечным, способным разряжаться и сгущаться, порождая тем самым все сущее. Воздух - это вещество с противоположными качествами. Он родственен душе человека. "Душа приводит в движение тело человека, а воздух - Вселенную". Гераклит - современник ионийских философов, рожденный в соседнем с Милетом полисе Эфесе, вошел в историю как один из первых исследователей собственно психической деятельности. Он ввел понятие «психея», на 
основе которого родились впоследствии понятия «психика» и «психология». Человек, по его представлениям, состоит из двух начал - души и тела [4].

Итак, обзор раннегреческого этапа философии позволяет говорить, что на начальных этапах бытие отождествляется с природой, для которого были характерны принципы «равновесия» «гармонии», «подобия».

Рассмотрим теперь понимание проблемы взаимоотношения (души и тела) в традиционной медицинской культуре адыгов, используя анализ лексического материала. Рассмотрим термин, «псау» - здоровый, корневая часть этого термина, по мнению А.К. Шагировапса, этимологически неотделима от псэ - душа. Суффикс -у (из -уы) означает «имеющее», «содержащее» [5, с. 89]. Таким образом, «псау» содержащий душу, тело, содержащее душу, т.е. единство тела и души, «живой», Согласно адыгейскому толковому словарю, псэ - «душа» определяется в первую очередь как бессмертное начало человеческой жизни, данное ему богом, а затем уже внутренний психический мир человека, его сознание, его мышление, и его третье значение - жизнь. Профессор З.И. Керашева провела лексико-семантический анализ лексемы псэ. Известный филолог отмечает, что psa (пса) «душа» в значении «жизнь» одинаково характерна для языков абхазско-адыгской ветви, а также, по её мнению, абхазско-адыгейское апсы // псэ и греч. psyche восходит к одному корню. Более того, она возводит наличие слова pasun, psun - «душа» к одному из древнейших языков, хаттскому [6, с. 7-11]. Важным и спорным у специалистов остается местонахождение псэ - «души» в теле. Так, 3.И. Керашева считает, что местонахождение неопределенно, вообще в теле [7]. По А.Т. Шортанову, местонахождение души адыги обозначают поразному: в сердце, в крови в горле. По нашим полевым материалам, большинство информантов на вопрос нахождения псэ показывают на горло. В связи с чем нам все таки представляется, что понимание псэ - «жизнь» у адыгов связано с воздухом, который одушевляет, дает жизнь. Основной путь движения псэ - горло (дыхательные пути), по которому оно входит и выходит из организма, но в самом организме оно пребывает везде, во всем теле [8, с.115]. По поводу вопроса о принадлежности псэ «души» 3.И. Керашева категорично отмечает, что ни в каких «народных» диалектах «вода», «земля», «растения» не имеют душу. Адыг никогда не соотнесет псэ - «душа» ни с водой, ни с растениями. Адыгейский язык четко разграничивает то, что имеет псэ 
- «душу» и лишено псэ - «души». Псау - «живой» относится к человеку и животным (диким, домашним), к птицам, насекомым - словом, ко всему, что бегает, плавает, летает, ползает [7, с 12].

На наш взгляд, существенным признаком, объединяющим живые организмы, имеющие псэ, является наличие органов дыхания, через которые поступает воздух в организм, и он получает псэ - «жизнь». Эти организмы так и называются «псэушхъ» «животные. Многие авторы считают, что слово «псэ» -- жизнь, одушевленность, позднее «душа» одного происхождения со словом «псы» - «вода». Известный языковед Н.Ф. Яковлев, считает, что слово «псэ» первоначально не имело религиозного значения, а было всеобъемлющим свойством всего живого.

Семантическая реконструкция слова псэ позволяет говорить, что первичным общим значением этого слова являлась «жизнь», которую давали две стихии - вода и воздух.

Вопрос о связи натурфилософии и медицины в историографии трактуется порой противоположным образом. Отечественный исследователь Д.А. Балалыкин, проанализировав ряд источников по данной проблеме, приходит к выводу, что в догиппократовский - досократовский период существует единое взаимодополняющее развитие натурфилософии как комплекса естественных наук и медицины как его части. По его мнению, можно говорить об особом типе рационального мышления древнегреческих врачей - натурфилософов, выражающемся в разрыве с грубой языческой мистикой, храмовой медициной и оккультным объяснением причин заболеваний. Им противопоставляются попытки понять болезнь как патологический процесс в организме, вызванный естественными причинами.

Из этого вытекают также естественные (физические и химические) методы лечения - диетотерапия, лекарственные средства, хирургическое вмешательство [9]. Рационалистические взгляды в медицине начинаются со знания анатомии, которая в свою очередь позволяет размышлять и познавать патологический процесс.

Адыгские лекари хорошо знали анатомию, строение скелета (пкъызэхэт), органов и тканей (пкъышъолъ), что позволило достичь значительных успехов в хирургии. В основе хирургических методов лечения лежали рациональные представления о патологических процессах в организме, проявляющихся в нарушении 
целостности органа: переломы костей (къупшъхъэ зэпык1ыгъ), вывихи, разрывы суставов (къупшъхъэ зэрыпк1ыгъ, зэрыутыгъ), ранения (у1агъэ). Соответственно методы лечения осуществлялись с помощью иммобилизации конечностей, репозиции костных отломков, извлечения инородных тел, обработки и лечения ран. О знании адыгами хирургической пластики и аллопластики свидетельствуют фольклорные и этнографические материалы. Медицинская наука XIX дала высокую оценку методам лечения ран и переломов у горцев Кавказа, в том числе адыгов.

Об искусстве горских лекарей в лечении переломов и ран русский военврач П.Попов писал так: «Громкая слава, которой пользуются горцы в лечении ран вообще, дала повод думать на Кавказе, что они владеют тайными средствами, неизвестными образованным европейским врачам. Это поселило между нашими больными особое доверие к горским врачам, многие раненые наши, даже офицеры, в приятной надежде на верное излечение прибегали и прибегают к горской медицине при первой к тому возможности» [10].

Одним из известных врачей древности, внесших неоценимый вклад в формирование научной медицины, является Гиппократ. Многие историки медицины и биографы древнегреческого врача Гиппократа считают, что, будучи врачом периодевтом (путешественником), он широко использовал в своей деятельности все рациональное в медицине многих стран и народов.

Так, М.П. Мультановский пишет: «Путешествия дали возможность Гиппократу познакомиться с достижениями древней медицины Индии, Египта и народов Малой Азии. В частности, Гиппократу стали известны медицинские знания скифов, проживавших на северных берегах Черного моря» [11] . В комментариях профессора В.И. Карпова к «Избранным книгам Гиппократа» отмечается: «Гиппократ был, несомненно, врач-периодевт. Из книги «О воздухе, водах и местностях» явствует, что Гиппократ по собственному опыту знает Малую Азию, Скифию, восточное побережье Черного моря у реки Фасис» [12]. Проведение сравнительного анализа материалов сборника Гиппократа и приемов этномедицины адыгов позволяет выявить ряд параллелей, позволяющих говорить о взаимовлиянии и возможных связях двух медицинских культур. Например, труд Гиппократа «О железах», в греческом железа aden, описывает железы здоровые - «губчатые, жирные, рыхлые, на ощупь они 
подобно щерсти» и «при их болезни делаются опухоли, шишки выходят наружу и жар овладевает телом».

В этномедицине адыгов были лекари, специализирующиеся на лечении адэ железа, болезнь железы - адэуз. Лекари выделяли две формы опухоли железы: адэхъу - мужская, незлокачественная, протекающая без выраженных клинических симптомов, и адэбзы, женская, клинически более выраженную, протекающую с сильным сердцебиением, похуданием и трудно поддающаяся лечению. В диагностике пользовались специальными камешками, прикладывание которых позволяло определить форму адэхъу (мужское), адэбзы (женское). В лечении использовались как рациональные, так и иррациональные методы.

Интерес представляет также решение вопроса о месте и роли специального питания для больных в древнегреческой медицине и в этномедицине адыгов. В одном из известных произведений «О древней медицине» повествуется о том, как древний человек, постепенно накапливая опыт в области медицины, подошел к решению вопроса о важности диеты в лечебном процессе. Гиппократ отдает дань уважения «так называемому медику и по общему признанию мастеру своего дела», который не только приготовил пищу для людей, отличную от звериной, но этот мастер своего дела изобрел специальную пищу для больных». В своей лечебной практике он настолько широко использует диету, что такие, казалось бы, безразличные кушанья и напитки, как птизана, водомед, кисломед, вино-вода, становятся главными лекарствами при заболеваниях внутренних органов. Так, в работе «О диете при острых болезнях» он широко применяет отвары ячменя с добавлением меда, вина или просто медовый напиток. В книге «Внутренние страдания» снова находим рекомендации по применению лечебных супов па основе чечевицы, ячменя, муки и т.д. с добавлением туда лука, чеснока и разных трав. Особой популярностью пользовался ячменный суп, процеженный и непроцеженный, называемый - птизана.

Сравнительным элементом адыгской народной медицины в данном случае может выступать древнее диетическое блюдо (почти забытое в настоящее время) «бэджынэ» - это сладковато-кисловатая похлебка, часто приготовляемая из ячменной, овсяной или кукурузной муки. Об этой древней пище упоминается в сказках, сказаниях, фольклоре. В известном адыгском сказании «Нарт Шэбатныкъорэ Чэчанэкъо Чэчанрэ» 
рассказывается, как во время болезни Чэчану захотелось «бэджынэ». Когда Чэчан пришел домой бледный и взволнованный, мать встревожилась и спросила сына: «Что случилось, может, ты заболел?» Чэчан ответил: « Да так, ничего, немного болит внутри, хотелось бы овсяной горячей бэджынэ со свежим медом». В адыгском фольклоре есть также поговорка « Сымаджэм бэджынэ икІас» (больной, люби «бэджынэ») [13, с. 2731.].

Несомненно, что проблема греко - варварских контактов сложна и трудно реконструируема. Тем не менее, приведенный материал позволяет говорить о связях древнегреческой медицины и медицины меотских племен (праадыгов).

Очевидно, что в регионе Средиземно-Черноморского бассейна периода античной цивилизации сложились благоприятные природно-географические и климатические условия для формирования культурно-цивилизационного пространства, образованию мощного информационного поля, позволившие процессу ноосферогенеза перейти на новый этап развития в понимании взаимоотношений человека и природы.

Необходимо также отметить, что в адыгской мировоззренческой культуре четко прослеживаются элементы первого этапа развития натурфилософских взглядов. В то же время надо отметить, что натурфилософские идеи имеют тысячелетний путь развития. Кроме первого этапа Милетской школы были еще классический (от второй половины V в. до н. э. до конца IV в. до н. э.) и эллинистический (с конца IV в. до н. э. до II в. до н. э.).

Однако дальнейшее развитие идей натурфилософии не получило развития в адыгской традиционной культуре. По всей видимости, причинами торможения и отставания в развитии мировоззренческой культуры были особенности социальноэкономического и политического развития меотских племен. Культурно-исторические процессы меотских племен обуславливались особенностями его пространственногеографического положения: с запада - Черное море, Керченский пролив и Азовское море, с юга - Северо-Западная часть Кавказского хребта, являющиеся естественными преградами, и открытость северо-восточных границ Донским степям, откуда шла постоянная угроза кочевых народов. Подъем социокультурного и экономического развития, которое испытали меоты в период расцвета Боспорского царства, сменился периодом упадка, вызванного усилением экспансии сначала сарматского кочевого ЭТНОФИАОСОФИЯ АДЫГОВ: ОТ МИФА К АОГОСУ : 
мира (III в. до н.э.) и последовавшим за ним нашествием аланских племен (I в. н. э.). Поступательное движение по пути консолидации и развития было окончательно прервано во время нашествия гуннов (IV в. н.э.).

Кочевники разорили земли меотов и территории Синдики и Боспорского царства. Это была крупнейшая катастрофа в истории адыгов [14, с.126-167]. Для того чтобы выжить в таких жестких условиях противостояния, сохранив свой культурный код, необходима была единая идеология, способная сплотить племенной союз. Такой идеологией оставалось мифологическое мышление, предлагающее единых богов и героев, способных консолидировать и мобилизовать общество в борьбе с врагом.

Таким образом, в этномедицине адыгов, преемников меотской культуры, в значительной степени нашли отражение натурфилософские взгляды, выразившиеся в определении первоэлементов жизни - воды и воздуха. Знания в области анатомии и рационалистический взгляд на ряд патологических процессов позволили достичь значительных успехов в области хирургии, методов лечения опухолей железы и диетического лечения внутренних болезней. Особенности исторического развития оказали значительное влияние на мировоззренческую культуру адыгов, который прошел сложнейший путь от устной традиции к логосу.

\section{Литература:}

1. Древнегреческая философия [Электронный ресурс] - Режим доступа: https://wikis.engrade.com/a341

2. Галут О.В. Социокультурные и цивилизационные процессы в Северном Причерноморье в Античную эпоху[Электронный ресурс] - Режим доступа: http://www.analiculturolog.ru/journal/archive/item/843-12-3.html

3. Анфимов Н.В., Аутлев П.У. Меоты - предки адыгов. - Майкоп, 1989; Анфимов Н.В. К вопросу о происхождении адыгов // Тезисы докладов на науч. сессии Северо-Кавказского совета по гуманитарным наукам.- Ростов н/Д: Изд-во РГУ, 1962. - 180 с.; Алексеев В.П. Происхождение народов Кавказа (краниологическое исследование).- М.:Наука. 1974.- 316 с.; Хотко С.Х. Страна меотов - прообраз Черкесии // АдыгэмакъМэлылъфэгъум и 27-рэ, 2016-рэ илъэс. 
4. Древняя натурфилософия [Электронный ресурс] - Режим доступа: http://old.pskgu.ru/ebooks/spass_1/spass_1_01_02.pdf

5. А.К. Шагиров Этимологический словарь адыгских (черкесских) языков А-Н. М.: Изд. «Наука».

6. 3.И. Керашева Лексико семантический анализ лексемы psa в адыгейских языках //Этюды по истории и культуре адыгов: Сб ст. - Майкоп: Меоты, 1998.

7. Там же.

8. Шортанов А.Т. Адыгская мифология. - Нальчик, 1982.

9. Балалыкин Д.А. Зарождение рациональной медицины в Древней Греции VI - IV вв. до н.э. [Электронный ресурс] - Режим доступа: http://cyberleninka.ru/article/n/zarozhdenie-ratsionalnoy-meditsiny-v-drevney-gretsii

10. Попов Н. Лечение ран у кавказских горцев // Военно-медицинский журнал. №1LXV. отД. IX. 1855.

11. Мультановский М.П. История медицины. - М.,1961. 348 с.

12. Гиппократ. Избранные книги. Перевод с греческого Руднева. - М., 1936. Ч.I-II.

13. Тхагапсова Г.Г. Народная медицина адыгов (историко-этнографический аспект). Майкоп, 1996.

14 Бетрозов Р.Ж. Этапы этнической истории адыгов: С древнейших времен до XVI века. - Нальчик, 1996.

Ачмиз К.Г.

\title{
Математические элементы в адыгской мифоэпической традиции
}

\begin{abstract}
Аннотация: В статье анализируются число и счет как элементь математических представлений, а также трансляцฺия первоначальных знаний в древней культуре адыгов. Впервые на эти проблемь обратили своё внимание Р. А. Ханаху и другие авторь в уникальной коллективной монографии «Мир культуры адыгов (проблемьл эволюции и изелостности)».

Ключевые слова: этническое сознание, эпос, сущее, число, счет, исчисление, трансляция знаний.
\end{abstract}

Понятие числа возникло в древности, в недрах первобытного общества как практическая потребность и усложнялось в процессе его эволюции. Самой древней математической деятельностью был счет. Счет был необходим, чтобы следить за поголовьем скота и вести обменный процесс. Некоторые древние народы подсчитывали 
количество предметов, соотнося их с различными частями тела, главным образом пальцами рук и ног. Отсюда, вероятно, возникло число, а вместе с ним возникла и математика.

В «Нартах» мы часто встречаемся с представлениями числа и счета. Так, в сказании «Как нарты, во главе с Орземесом, спасли от испов Сатаней» есть такой примечательный фрагмент. Когда молодые нарты приехалиэ к Орземесу с просьбой помочь им овладеть крепостью испов, разбить врагов и освободить Сатаней, он ответил:

- Я бы согласился помочь вам, если бы с нами в поход отправился нартский свинопас Горгъоныж. Он хитер и смел, хорошо бы проверить его сметливость и силу.

- Будет по-твоему! - сказали молодые нарты и отправили на смену свинопасу юношу-пастуха. Тот нашел Горгъоныжа вместе с его стадом на большой горе.

- Да умножится нартское стадо! — приветствовал юноша-пастух свинопаса.

- Да будет так! — отвечал Горгъоныж.

- Нарты отправляются в поход и хотят взять тебя с собою, я же пока постерегу твое стадо.

У нартов было такое огромное стадо свиней, что сберечь его мог только свинопас Горгоныж.

- Не так-то просто охранять стадо, - сказал Горгъоныж. - Если ты скажешь, сколько свиней в этом стаде, тогда я смогу оставить на тебя мое стадо, а сам отправлюсь в поход.

- Откуда же я знаю, сколько тут свиней?

- Ладно, я скажу тебе, а ты сосчитай: больших - девять, широкорылых - десять, буропегих - одиннадцать, с короткими хвостиками - восемнадцать, разношерстных тридцать, одношерстных - тридцать, да у каждой свиньи по тридцать поросят. Сколько же всего?

- Никак не сосчитаю, - ответил пастух, постояв в раздумье.

- Ну, какая же ты мне замена? - и Горгъоныж отослал юношу-пастуха обратно.

Прислали второго, но и он не смог сосчитать, сколько свиней было в стаде. И его Горгъоныж отослал обратно.

Выслушали нарты незадачливых пастухов и послали третьего.

Третий нарочно замешкался в дороге. 
- Что ты так долго не шел? - сердито спросил его Горгъоныж.

- Нарты мололи белое просо, я остался считать зерна.

- Ну, раз ты можешь сосчитать зерна, значит, можешь заменить меня здесь. Оставайся, будешь съедать в день столько пасты, сколько можно взять за три раза лопаточкой, да три окорока. Не хватит, - можешь добавить, - сказал свинопас и, сев на кабана, поехал к Уазырмесу.

Из этого сюжета следует, что пастух Горгъоныж, подсчитывая свои стада, производит в уме следующие математические операции:
$9 \times 30=$
$10 \times 30=$
$11 \times 30=$
$18 \times 30=$
$30 \times 30=$

и плюс сумма всех этих произведений.

Решение такого рода примеров - показатель высокой способности к отвлеченному мышлению, когда снимается качественная определенность вещи, и человека интересует лишь количество. В некотором роде это сведение единичных, неповторимых сущностей к одной сущности, нивелирование, выделение общего. Конечно, нарты, говоря о числе при счете, соотносят, описывая внешность животных. Например, 10 черных, 9 полосатых, 11 тупорылых и т. д. Но сама необходимость перемножать и складывать это в уме - одно из подтверждений, что нарты склонны к отвлеченному мышлению. Некоторые числа, правда, еще метафоры, присказки: 7,3,9,100. Но в практической жизни нартов эти присказки имеют мало значения, это лишь для афористичности, для украшения речи используется. В эпосе нет магии счастливых и несчастливых чисел.

Числовые параметры в адыгской мифопоэтической традиции - один из элементов знаковой системы, структурирующих, описывающих окружающую действительность. Как и в большинстве культур, считает 3.Ж. Кудаева, в адыгской мифологии «числа и счет имели «космизующий» характер, отражали количественные и качественные параметры вселенной».

Число «один» у адыгов обозначает не столько начальный элемент числового ряда, сколько целостность, единство, связанное с образом «совершенной целостности» (Зы Тхьэ и закъуэщ. Тха - един). Сравни (Зыр - Алыхьырщ - Аллах един). 
Число «два» также в непосредственной форме представлено в адыгских паремиях - пословицах и поговорках. Но при этом следует отметить, что в приметахправилах четность обладает негативной семантикой.

Например: Унэ пщІымэ бгыкъу зэпэбж иумылъхьэ, жаІэрт. - Когда строишь дом, не клади четное количество балок, - говорили.

Число «три», к примеру, является одним из определяющих числовых элементов в большинстве этнокультурных традиций и «первым числом» в ряде архаических культур (например, древнекитайской). Трехчленная вселенная у адыгов включает в себя, как известно, срединный, нижний и верхний миры, причем последние разделяются еще на семь ярусов (щІыкъатибл). Число «три» находит также широкое применение в адыгских паремиях: пословицах, поговорках, приметах, загадках. З.Ж.Кудаева приводит на этот счет много примеров, которые бытуют в адыгской среде и по сей день [6].

В адыгской мифологии, так же, как и в мифологии других народов, особым почетом пользуется число «семь». Небо у них имеет семь этажей, а земля - семь подземелий (редко - девять катов - этажей).

Географическое распространение этого фольклорно-этнографического явления весьма обширно, и можно сделать вывод, что пиетет числа «семь»- явление почти повсеместное. У адыгов созвездие «Большая медведица» называется «Семь братьевзвезд». Вселенная делится на семь частей; Земля состоит из семи частей; Идол Созериша имеет семь сучьев; Идол Ханцегуаще поливают водой из семи ведер. Соусрыкъо делит свою силу на семь частей. Иныжи-великаны - семиглавые. Адыгские герои мифов, сказок и эпоса скачут «семь дней и семь ночей», переходят «семь речек и семь перевалов» и т.д.

И как утверждает А. Шортанов, «почитание числа семь - явление дорелигиозное, но оно было впоследствии использовано как «готовый материал» для сакраментальных целей. Символическое значение числа «семь» в адыгском эпосе обстоятельно рассмотрено в работе М.А. Кумахова и 3.Ю. Кумаховой. У адыгов (черкесов) широко распространена двадцатеричная (двадцатичная, вигезимальная) система счисления позиционная система счисления по целочисленному основанию 20. 
Следует заметить, что 20-ричная система - вторая по распространенности после десятичной. Считается, что она, как десятичная и двенадцатеричная, связана со счетом на пальцах. Широкое распространение она получила во многих языках народов Африки, Америки, Азии, Европы, в том числе на Кавказе. В частности, в грузинском, например, 11 t'ert'meti < at'-ert'-meti (10-1-больше), 12 t'ormeti; счет здесь идет по двадцаткам (20 otsi, 40 ormotsi < or-me-otsi (2-20), 50 — ormotsdaati < ormotsi-da-ati (два раза двадцать и десять, (сорок и десять), 70 (samotsdaat'i < sami-otsi-da-at'i (3-20-и-10). Имеется в виду вместо слов «тридцать» или «тридцать один» говорится как бы «двадцать десять», «двадцать одиннадцать» и т. д. А, например, 97 - (четыре по двадцать и семнадцать) В абхазском 20 - өажәа, 30 - өажәижәаба (двадцать десять), 40 - өынєажәа (два раза двадцать), 50 - өынєажәижәаба (два раза двадцать и десять, «сорок десять»), 78 - хынєажәижәаба жәаа (три раза двадцать восемнадцать)

В адыгейском 11 пшІыкІузы (пшІы 10, зы 1), 20 тІокI, 30 щэкІы, 40 тІокІитІу, 90 - четыре по двадцать и десять)

В нахско-дагестанских языках (у ингушей, чеченцев, аварцев, лезгин) также принята 20-ричная система.

Двадцать (hogei) используется в языке басков как основание исчисления чисел до 100. Баскский политический деятель Сабино Арана (1865 - 1903 гг.) даже предлагал ввести двадцатиричную систему в письме, чтобы она соответствовала разговорному языку.

Полагаем, что наличие системы счисления у народа - это первый шаг к возникновению письменности.

Ученые давно заметили, что западнокавказские дольмены (далее - ЗКД) обладают пропорциональностью конструкции, однородностью размеров и могут быть, по мнению известного этнографа В.А. Дмитриева, «причислены к памятникам архитектуры с большим основанием, чем другие мегалитические сооружения». Для доказательства столь смелого научного вывода В.А. Дмитриев, опираясь на свои собственные промеры, а также промеры, произведенные сотрудниками ЛОИА АН СССР А.Д. Резепкиным, ГМЭ Е.А. Глинским и другими, проанализировал десятки дольменов из 11 местоположений на территории Адыгеи, Кубани, Причерноморской Шапсугии и Абхазии и пришел к уникальным выводам. Одной из причин отнесения ЭТНОФИАОСОФИЯ АДЫГОВ: ОТ МИФА К АОГОСУ : 
ЗКД (этих погребальных сооружений и своеобразных святилищ) к памятникам архитектуры является тот неоспоримый факт, что их облик рассчитан на восприятие внешним наблюдателем. Трапецевидность ЗКД во всех проекциях и особенно фасада подтверждает, что строители ЗКД обладали математическими познаниями и пользовались «размерным модулем», высокой для своего времени степенью точности. По мнению В.А. Дмитриева, которое мы разделяем, «такой модуль не мог быть абстрактной единицей измерения и должен иметь физический и ритуальный смысл».

Исследователи ЗКД для пространственного описания памятников пользуются измерениями, полученными в современных метрических единицах или условными единицами, установленными произвольно. Но гораздо продуктивнее пользоваться теми метрическими мерами, которыми пользовались древние архитекторы и строители. Не подлежит сомнению, что все ЗКД «местного производства» изготовлены древними людьми, проживавшими на этой территории. Каждый метод измерений имеет право на существование, но метод, предложенный В.А. Дмитриевым, позволяет проникнуть в менталитет людей архаической культуры, поскольку «изучение созданий человека невозможно без попыток понять мотивы его действий».

Представленные В.А. Дмитриевым статистические величины весьма показательны и подтверждают тезис об унифицированности размеров ЗКД. Встречающаяеся порой неоднорядность ЗКД объясняется хронологическими или социальными причинами, что не исключает также существования различных локальных традиций внутри даже одной группы ЗКД, будь то агломерат или кладбище. Промеры, а также непосредственное внешнее наблюдение показывают, что все ЗКД отличаются максимальной однородностью, а также внутренней ритмичностью, которые касаются облика и положения входного отверстия в передней плите. В нашу задачу не входит подробный анализ методики выявления средней величины. Отметим только, что промеры проводились по трем измерениям (горизонтальный и вертикальный диаметр и высота нижнего среза отверстия) и по ним вычислялась средняя величина. Затем величины средних и их разности сравнивались между собой до получения максимальной единицы, кратное повторение которой дают средние данные по группам измерений. Близость величин единиц и малая статистическая погрешность позволяют предположить, что при разметке плит ЗКД могла применяться линейка - эталон. 
Известно, например, что линейка с ценой деления в 6,7 см была известна в Древней Индии.

В нашем случае, скорее всего, единица измерения является такой мерой, как ширина ладони или как длина вытянутого среднего пальца руки. Ширина ладони имела широкое применение в древнем Шумере и особо в античном мире, где была известна под римским термином «пальма», имеющая размер 7,3 см. Ширина ладони активно использовалась в прошлом в северокавказской традиционной метрологии. У адыгов она называется «бжымы» (кулак) - расстояние от места сгиба указательного пальца до места сгиба мизинца в кулаке, равное 7-8 см; у карачаевцев - «сюем»; у осетин - «мустук». Проведя необходимые промеры между тремя размерными характеристиками: высотой всей плиты, высотой расположения отверстия и вертикальным диаметром отверстия, В.А. Дмитриев получил численный ряд: 7 - $11-14-17-21-25$ - 28 - 32 - 35 единиц. В этом ряду трудно не увидеть повторение числа СЕМЬ и его половинок ТРИ и ЧЕТЫРЕ. Подобная картина не может быть случайной, т.к. известно, что числа 3 и 7 типичны для астральной символики большей части населения Старого Света. Позднее в учении пифагорейцев почитание сакральных чисел вылилось в форму «Все есть число семь».

Подробные расчеты, произведенные В.А. Дмитриевым, привели его к выводу, что в большинстве случаев вид передней плиты ЗКД соответствует т.н. «золотому сечению». Иоганн Кеплер говорил: «Геометрия владеет двумя сокровищами: одно из них теорема Пифагора, а другое - деление отрезка в среднем и крайнем отношении (то, что в математике называется золотым сечением - К.А.)... Первое можно сравнить с мерой золота; второе же больше напоминает драгоценный камень». «Золотое сечение» - совершенно ординарная точка на обычном отрезке. А между тем ею обеспечивается присутствие красоты, соразмерности всех частей. Это в полной мере относится к ЗКД.

Анализ текстов адыгского героического эпоса позволяет нам отыскать некоторые элементы формирующегося знания. Обнаруживается такая линия: мудрец (знания у него из природы) - бог (узурпатор знаний) - человек, делающий орудие для другого человека. Это как бы схема трансляции знаний, а коммуникация идет от человека к человеку. Здесь мы видим, что человек одновременно совмещает в себе и ум мудреца, и физическую мощь бога. 
Богам вообще отказано в уме, у них нет инициативы, их лишь со стороны тревожат люди. Ацаны, в абхазском варианте эпоса, например, считали себя воспитателями племянника по сестре бога или даже его сына и потому считали себя его молочными братьями (ахупха). Они считали, что превосходят бога по уму и что он желает выведать у них уязвимые места. «Ахъахьы ажвгІванд - ацІахьы хІара. Анчва дызусуда?» - «Наверху небо - внизу мы. Кто такой бог?»- говорили ацаны. Все эти богоборческие мотивы - один из элементов предфилософского сознания, когда человек недоволен, неудовлетворен простой отсылкой к богу по поводу того, откуда то или иное знание. Человек сам находит и фрмирует знание.

Эпос фундирован верой в разум человека, в его умственные возможности. Здесь утверждается то, что будущее за людьми, которые будут умнее нас: «Ркъару мачІызтІхІва гІамальла йкьазопI» - «Хоть и мало у них сил, зато богаты амалью». Амаль здесь - способ, средство, прием. Кстати, у адыгов (черкесов) этот термин до сих пор имеет широкое распространение. Саусрыкъо устает потому, что он не ищет амаль: «Амаль дгьащтамта дгІагситІ». Именно поисками амаль, нарастанием этих поисков отличается каждый этап в развитии человека в системе мифосознания. Решение той или иной задачи героем на каждом этапе отличается применением все больших умственных усилий и все меньше физических. Саусрыкъо побеждает иныжа благодаря тому, что он хитрее и умнее его, несмотря на мощные физические возможности второго. Далее, таких как Саусрыкъо, побеждают маленькие люди, которые пришли после нартов. Эти люди, хотя и не имеют таких физических возможностей, как нарты, зато имеют множество способов решать те или иные жизненные задачи.

В подтверждение этого можно привести пример, когда Саусрыкъо спрашивает у своей девушки, к которой он приехал накануне своей гибели: «Почему собака, лежащая у порога, не проснулась, а щенок, лежащий у нее в утробе, залаял на меня?»

Девушка отвечает: то знак того, что будущие потомки будут жить, опережая старших, споря с ними, побеждая их, встанут на ноги в борьбе с ними.

Таким образом, прогресс, становление и развитие общества людей возможны только в борьбе (здесь имеется в виду «борьба» в спорах, в делах).

Возвращаясь к понятиям смысла и содержания математических представлений в мифоэпической традиции адыгов и других древних народов, отметим, что возможность 
воспроизведения числа и вместе с ним счета значительно увеличилось с появлением письменности, ибо математика или арифметика как наука о числах появились раньше письменности. Как утверждает Платон, числа, как и письмена, были изобретены в Египте. Первое время числа обозначались черточками, на каком-нибудь материале, например, папирус или глиняные таблички.

Так, на территории современной Кубани и Адыгеи археологии нашли множество так называемых «меотских таблеток». По утверждению неординарно мыслящего ученого Н. Г. Ловпаче, это керамические плитки с изображениями в функции своеобразного хеттско-меотского алфавита. Кроме культовых символов и геральдики, на плитках рассматриваются иероглифы, силабы, пиктограммы, которые имеют аналогии среди знаков хеттского письма 2-го, 1-го тыс. до н.э. Можно предположить, что «меотские таблетки» последних веков до н.э. есть продолжение иероглифической письменной традиции Майкопской плиты поздней бронзы на Северо-Западноэм Кавказе [22].

По мнению того же Н.Г. Ловпаче, следствием появления «меотских таблеток», стало массовое возрождение этой письменно - знаковой системы иероглифического характера в Фитии - Керкетии Северо-Западного Кавказа в античную эпоху, когда вокруг этого региона была распространена эллинская письменность [22].

Надо особо отметить, что наличие всякого рода символов создавало возможность замены действий и предметов, и постановки на их место слов либо путем передачи их смысла, как это имеет место в китайском языке или египетских иероглифах, а в нашем случае в «меотских таблетках» - памятнике иероглифического письма как предтечи протоадыгской письменности.

Окончательное упрощение алфавита до его современного вида, где символы означают звуки, а не слова, произошло лишь в железном веке. Таким образом, «письменность, это величайшее из изобретений руки и ума человека, постепенно возникла из счета» [23].

\section{Литература:}

1. Мир культуры адыгов (Проблемы эволюции и целостности) / Сост. и научн. редактор Р.А. Ханаху. Майкоп: ГУРИПП «Адыгея». - 2002. - 516с. 
2. Гегель Г. Сочинения. М.,1932. Т. IX. С. 58-59.

3. Шенкао Г.Х. Элементы предфилософии в эпосе. // Мир культуры адыгов. Майкоп, 2002. - С. 86-96.

4. Шенкао Г.Х. Элементы предфилософии в эпосе. // Мир культуры адыгов. Майкоп, 2002. - С. 89.

5. Шенкао Г.Х. Указ. соч. - С. 89.

6. Кудаева 3.Ж. Мифопоэтическая модель адыгской словесной культуры. Нальчик, 2008. - С. 98.

7. Кудаева 3.Ж. Указ. соч. - С. 104.

8. Кудаева 3.Ж. Указ. соч. - С. 98.

9. Кудаева 3.Ж. Указ. соч. - С. 99.

10.Шортанов А.Т. Адыгская мифология. - Нальчик, 1982. - С. 75.

11.Шортанов А.Т. Указ. соч. - С. 75.

12.Кумахов М.А., Кумахова 3.Ю. Нартский эпос:язык и культура- М.: Наследие, 1998. -312 c.

13.Дмитриев В.А. Малая мера дольменов Западного Кавказа // Вопросы археологии Адыгеи. - Майкоп, 1992. - С. 224.

14.Дмитриев В.А. Указ. соч. - С. 224.

15.Антонова Е.В. Очерк культуры древних земледельцев Передней и Средней Азии. - М.: Наука, 1984. - С.4.

16.Володарский А.М. Отдельные отрасли науки в Древней Индии // Очерки истории естественно - научных знаний в древности. - М.: Наука, 1982. - С. 159.

17.Брокгауз Ф.А. и Ефрон И.А. Энциклопедический словарь. - СПБ, 1984. - Т. XXII. - C. 649 .

18.Аутлев П.У., Алибердов Т.Д. О народной метрологии адыгов (черкесов) // Ученые записки АНИИ. - Майкоп, 1968. - Т. VIII. Этнография. - C. 93.

19.Карачаевцы /отв. ред. Лавров В.И. - Черкесск, 1978. - С. 282.

20.Абаев В.И. Историко-этимологический словарь осетинского языка. - М. - Л.:

Наука, 1973. - Т. 2. - С. 134.

21.Дмитриев В.А. Указ. соч. - С. 236. 
22..Ловпаче Н.Г. «Меотские таблетки» - памятник иероглифического письма

Северо-Западного Кавказа//Язык, письменность и алфавит: актуальные

проблемы их взаимодействия. Материалы международной научно-практической конференции, Майкоп. 26-27 октября 2016 г. - С. 118.

23. Дж.Бернал. Наука в истории общества. М.1956. - С.74. 


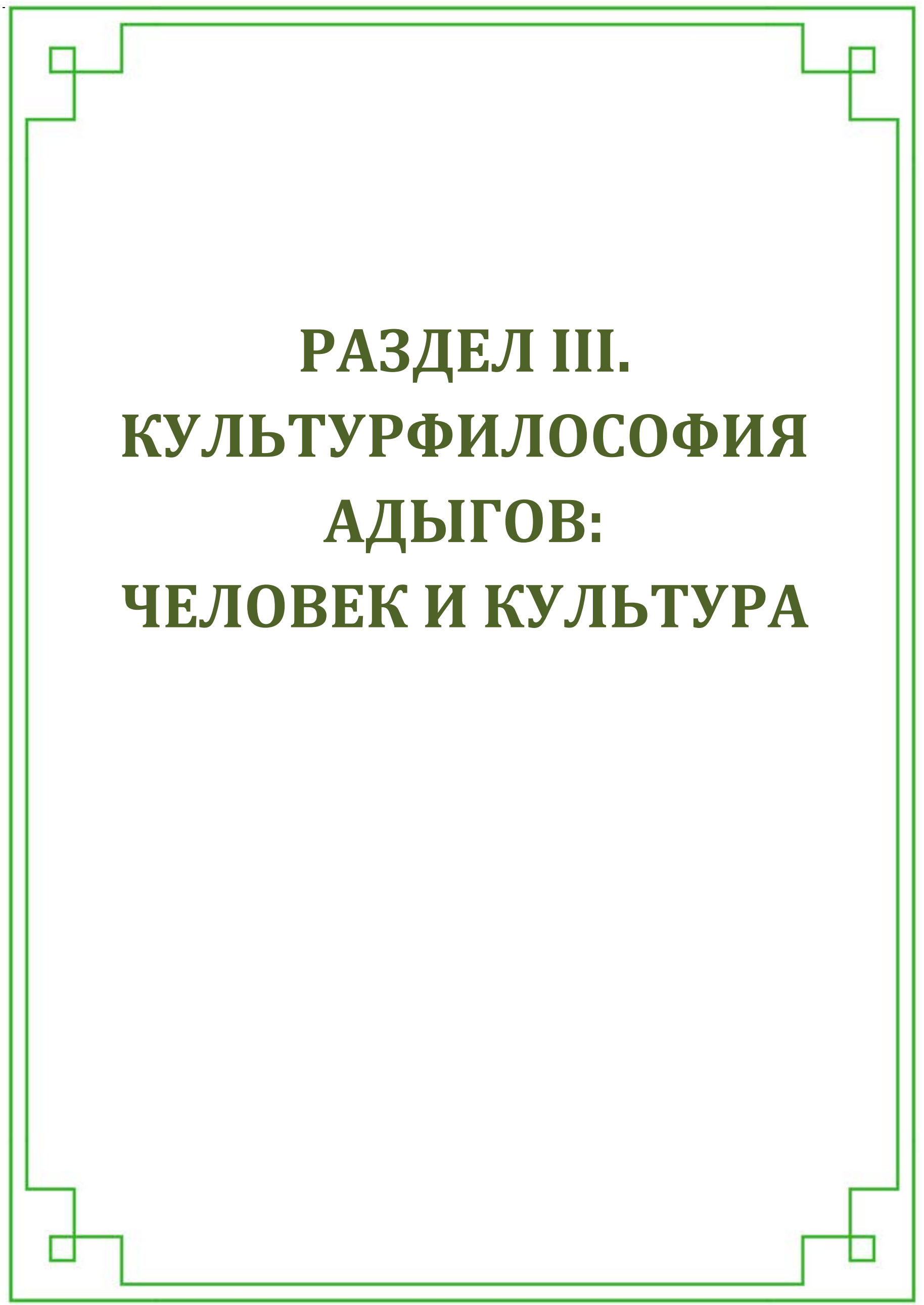


Шадже А. Ю.

\section{Адыгея в современном культурно-идентификационном}

\section{пространстве России}

Аннотация: B статье рассматривается культурная идентичность человека в контексте современной постнеклассической науки. Целью исследования является определение идентификационных особенностей Адыгеи в современном социокультурном пространстве России, а также осмысление тезиса о необходимости укрепления российской национальной идентичности. Что касается адыгского этноса, то свое существование и дальнейшее развитие, безусловно, он связывает только с Россией, только в составе российской гражданской нации, только в соииокультурном пространстве России.

Ключевые слова: культура, диалог культур, идентичность, этнокультурная идентификачия адыгов, российская наџия, соџиокультурное пространство.

Акутальность постановки проблемы. Чтобы тот или иной фундаментальный вопрос был услышан и обсужден, необходима определенная социокультурная атмосфера, способствующая пониманию сути вопроса (или проблемы) и готовая помочь в его разрешении. Представляется, что сегодня вопросы идентичности широко обсуждаются в различных областях, и можно говорить о том, что научная общественность находится в стадии перехода от научных разработок к практическим рекомендациям по их применению. При этом важно различать восприятие и практическое использование базовых идей идентичности в конкретных областях знания и восприятие их не только специалистами, но и культурой в целом, обществом и практиками.

В современной гуманитарной науке идут поиски определения путей интеграции граждан России и укрепления российской национальной идентичности в регионах.

Решение этой проблемы имеет теоретическую и практическую значимость, поскольку она связана с сохранением единства и целостности России, чтобы она не раскололась на «этнические квартиры», a, сплотившись, сохранив свое этноконфессиональное разнообразие, заняла свое достойное место в глобализирующемся мире.

В контексте модернизации нашей страны поставленная проблема приобретает дополнительную актуальность: нужно добиться того, чтобы курс на модернизацию сплотил наше российское общество. 
Научная и практическая значимость ее в региональном и этнокультурном измерении самоочевидна, поскольку она связана с необходимостью совмещения этнической, региональной и российской национальной идентичностей со сложной структурой северокавказской общности.

Наиболее явственно ощущается потребность в укреплении российской национальной идентичности в одном из проблемных регионов России - СевероКавказском, который является сложнейшей, исторически сложившейся системой, характеризующейся своей структурированностью, полиэтничностью, поликонфессиональностью и повышенной социальной, экономической и этнополитической напряженностью. В процессе социокультурной трансформации исторически сложившаяся здесь этническая карта подвергалась серьезной деформации. В последние десятилетия стал нарастать динамизм в межэтнических взаимодействиях и отношениях в переходе от традиционных норм и форм жизни к инновационным, в переоценке социокультурных ценностей. Эти процессы уже размыли традиционные социокультурные основы народов северокавказского сообщества, однако, как показывают наши исследования, не привели к ослаблению роли этнического фактора, который остается одним из параметров порядка, а потому и влияющей доминантой на ситуацию. Это актуализирует поиски оптимального соотношения традиций и инноваций, механизмов самоорганизации и управления социальным развитием, а также процессом формирования и укрепления российской национальной идентичности на Северном Кавказе.

В условиях активизации этнического и религиозного самосознания нелинейное взаимодействие этнокультурной, региональной, российской национальной идентичностей протекает довольно остро и напряженно. При этом российская национальная идентичность не стала доминирующей, образ «россиянина» слабо воспринимается в массовом сознании и в элитарных кругах.

Более того, отсутствуют концептуальные основы совмещения разных видов идентичностей (этнокультурной, региональной, религиозной и т.д.), интеграционный потенциал российской национальной идентичности еще не выявлен, не используются ее эвристические возможности в разработке региональной национальной политики. 
Проблема заключается в том, что, во-первых, необходимо теоретически и практически определить основы полиэтничного единства российского общества, основы нашей национальной солидарности и идентичности, общих интересов и ценностей: духовных, политических, этнических, социальных и т.д., во-вторых, укрепляя единство россиян, сохранить этнокультурное разнообразие.

Цель данной статьи - рассматривая идентичность в контексте современной, постнеклассической науки, определить идентификационные особенности Адыгеи в современном социокультурном пространстве России и осмыслить тезис о необходимости укрепления российской национальной идентичности. Некоторые предварительные замечания. Рассмотрение идентичности, в частности российской идентичности, в контексте современной науки позволяет выделить ряд положений.

Первое связано с тем, что идентичность является открытой системой, вступающей во взаимодействие с различными видами идентичности. Именно эта характерологическая особенность позволила ей приобрести множественный характер в современном мире. Это неудивительно, поскольку идентификация идентичности осуществляется по разным основаниям. Идентифицировать себя человек может на разных уровнях. Человек вынужден всегда определять себя, тем более в условиях постоянно меняющейся ситуации. Идентифицировать себя ему приходится постоянно, независимо от окончательной определенности той общности, к которой он себя относит. Ведь сама эта общность есть величина постоянно меняющаяся, как впрочем, и самоидентифицирующийся человек.

Отсюда следует, что самоидентификация представляет собой открытый процесс. Идентичность является открытой системой, вбирающей в себя различные виды идентичности.

Совершенно справедливо отмечает 3. Бауман, что «вместо разговора об идентичностях, унаследованных или обретенных, более уместным и соответствующим реальностям глобализирующегося мира выглядело бы исследование идентификации, никогда не заканчивающейся, всегда незавершенной, неоконченной, открытой в будущее деятельности, в которую все мы по необходимости либо сознательно вовлечены» [1]. 
Таким образом, идентичность можно рассматривать как объемный, многогранный и собирательный концепт, вбирающий в себя содержание множества разных идентичностей. Перефразируя О.Н. Астафьеву [2], можно заключить, что «открытость концепта и его качественные характеристики позволяют вписать его в концептосферу постнеклассической науки», тем самым, отмечая его отличие от классических определений идентичности.

Второе положение вытекает из предыдущего - идентичность не является некой исторической заданностью, имеющей статичный характер.

В этой связи кратко сформулируем два взаимосвязанных тезиса: во-первых, идентичность - подвижная категория, несмотря на то, что в ней сохраняется некоторое инвариантное содержание, определенное ментальностью народов того или иного общества; во-вторых, идентичность всегда вписана в определенный социокультурный контекст, формирующий ее содержание.

Раскроем эти тезисы на примере Северного Кавказа, являющегося сложнейшей, исторически сложившейся гео-, экономико-, политико-, социо-, этнокультурной системой. В ее функционировании важная роль принадлежит этническому фактору и этнокультурному разнообразию. Сущностью рассматриваемого сообщества является культура (этнические культуры) и ее базисные ценности. Несмотря на «модернизацию традиционности», этнический фактор продолжает играть важную роль в регионе. Этнокультурные традиции, составляя основу самобытности, остаются наиболее устойчивыми элементами в рассматриваемой системе. Ценность сущности культурной самобытности в ее социальном потенциале.

Именно поэтому в современной ситуации важно понимание эвристического потенциала этнического фактора и использование его в практической жизни.

Совмещение разных видов идентичностей - непростая проблема. Многолетние исследования нашего коллектива показывают, что этническая и российская идентичности не исключают друг друга. Разные уровни идентичности (этнокультурная, региональная, российская национальная идентичности) сосуществуют по принципу взаимной дополнительности [3]. Основой сосуществования их могут стать общие базовые ценности - исторически сложившиеся социокультурные ценности, на основе которых получат свое развитие этнические и региональные общности в составе ЭТНОФИАОСОФИЯ АДЫГОВ: ОТ МИФА К АОГОСУ : 
российского полиэтничного общества в условиях формирующейся российской гражданской нации.

Третье положение - необходимость усиления междисциплинарного и полипарадигмального подхода в исследовании идентичности. Методологически корректная соотнесенность концепций, понятий, положений разных дисциплин позволяет рассмотреть одни и те же проблемы с различных позиций, способствует не только объективной оценке социальных процессов, но и осмыслению идентичности в контексте динамики прошлого, настоящего и будущего. Междисциплинарный анализ, с одной стороны, выводит на целостное осмысление региона, направленное на определение путей развития. С другой стороны, такой подход дает холистическое видение проблемы идентичности, позволяет вписать ее в контекст российских и глобальных изменений, рассматривая «горизонтальные» и «вертикальные» связи и изменения на разных уровнях идентичности.

Сочетание разных методологических подходов позволит глубже раскрыть и понять сложившуюся в регионе социальную реальность. А это, в свою очередь, нацелит на социальную интеграцию населения и определение путей мирного развития региона.

В рамках современной науки возникает возможность понять и объяснить функционирование северокавказского общества как сложной нелинейной саморазвивающейся системы. К примеру, методологическая специфика синергетического анализа полиэтничного общества выявляет доминирующие на данном этапе параметры порядка, вскрывает механизм развития, указывая на наличие в обществе альтернативных путей его развития, а также показывает, что развитие носит необратимый характер [4].

Безусловно, здесь необходимо учитывать особенности самой синергетической методологии к изучению общества как неприродной системы. Как справедливо отметил М.С. Каган, отличительное качество социальной реальности - «зависимость соотношения сил порядка и хаоса в историческом процессе не только от объективных факторов и от случайностей, особенно действенных в состояниях бифуркаций, но и от свободы воли исторических деятелей, микро- и макрогрупп, а в определенных обстоятельствах и народных масс». Другая особенность синергетического анализа общества - возможность «стихийного и сознательного порождения хаоса» [5]. ЭТНОФИАОСОФИЯ АДЫГОВ: ОТ МИФА К АОГОСУ : 
Сказанное позволяет утверждать, что от деятельности человека зависит «стихийное или сознательное порождение хаоса» в обществе, а значит, и само существование общества. Поэтому есть основание считать, что стиль мышления, с одной стороны, определяет познание и переосмысление функционирования северокавказского общества, с другой - судьбу общества. Если линейное мышление, особенно руководителя, разрушает общество, то нелинейное поддерживает его саморазвитие. Это касается формирования российской идентичности и ее укрепления.

Пятое положение вытекает из предыдущего: важный источник идентичности память. Другими словами, идентичность можно рассматривать как ценностномировоззренческий феномен. В рамках новой конструктивистской методологии представляется возможным в центр исследовательского внимания поставить сознание и поведение человека, его место и отношение к другим не просто как отдельного индивида, но и члена определенной социальной и этнической группы, представителя определенного общества, определенной социокультурной среды (Ж.Т. Тощенко). Более того, данная методологическая стратегия направлена на реализацию программы поиска актуальной идентичности «кто я?» или «кто мы?» в определенном обществе и в современном социальном мире. В этом контексте память можно рассматривать как некоторое отношение к другому, которое обладает специфическими формами существования и определенными способами постижения своего содержания.

Память ценна тем, что она соединяет человека с прошлым, формирует представление родины и чувство самосознания. Пренебрежение к прошлому нарушает естественный процесс саморазвития этноса и нации. Глубинные аспекты истории довольно активно работают на формирование идентичности. Память связывает прошлое, настоящее и будущее. Прошлое зафиксировано в разных формах памяти. Безусловно, прошлое в современной жизни приобретает новое содержание. При оценке прошлого из настоящего мы соотносим его с современностью, а это позволяет выявить новые смыслы прошлого, что изменяет контекст существования прошлого. Поэтому мы находим в прошлом новое содержание, новый смысл и новое понимание, помогающее думать и мечтать о будущем. 
Итак, одна из общих исторических компонентов единства российского полиэтничного общества - наше историческое прошлое, наша историческая память, память российской нации, которая хранит ключевые события страны.

Шестое положение связано с осмыслением прошлого опыта в нашей стране. Говоря о формировании российской идентичности, есть смысл обратиться к советскому периоду. Безусловно, это трагичный и сложный период, и его нельзя рассматривать по схеме «черный-белый». Однако осмыслить значение «советскости» как социокультурного феномена в духовной истории российского народа весьма поучительно.

Надэтническая идентичность «советскость» формировалась в рамках советской культуры. Под этой общностью понималась самоидентификация с Советским Союзом, определение «кто мы?» по отношению к своей стране. На формирование этой идентичности работали культура, политика, вся идеология страны. Безусловно, наблюдалась чрезмерная идеологизация. Тем не менее, ценностный смысл этого феномена заключался в том, что он работал на сплочение и единение граждан, а также им задавался некоторые параметры развития страны.

Понимание надэтнической общности в современной России основано на новых ценностно-мировоззренческих ориентациях, которые формируются на основе гражданской культуры с сохранением социокультурного разнообразия. Понятно, что многие сложившиеся формы в прошлом не вписываются в современность. А вот содержание, ценностный смысл, созвучный современности, напрашивается на переосмысление и использование. Например, ценным является опыт формирования чувства принадлежности к единой стране, именуемой Советским Союзом. «Советскость» позволяет выявить новые смыслы прошлого, что изменяет контекст существования прошлого.

В связи с этим востребованным является формирование представлений о конструктивной роли надэтнической общности, которая рассматривается как духовное единение граждан страны, как механизм преодоления напряженности в российских регионах. На рассматриваемую проблему стоит посмотреть именно с этой точки зрения. 
Седьмое положение связано с тем, что в современном контексте необходимо рассмотрение идентичности не только на рациональном, но и на иррациональном уровне.

В современных условиях активизируются религиозный фактор и религиозная идентичность. Важно сказать об отношении к исламу. Здесь отметим лишь тот факт, что в связи с экстремизмом и терроризмом растут мифы вокруг ислама. О нем судят по фундаменталистам, хотя именно они искажают ислам. В связи с тем, что в последнее время агрессия, злоба, ненависть друг к другу культивируют многие заинтересованные лица, засоряя наше социокультурное пространство, есть смысл осмыслить и переосмыслить религиозную идентичность в полиэтноконфессиональном регионе. При этом не отождествляя ислам с ИГИЛ.

Наконец, последнее положение касается необходимости укрепления единства российского общества, т.е. российской идентичности в условиях глобализации. Глобализация оказывает активное влияние на наше культурное самосознание: как позитивно, так и негативно. Поэтому все страны обеспокоены своей национальной идентичностью. Здесь важно вспомнить, что в современной гуманитарной науке существует различное ценностное отношение к национальному. В этом плане показателен постмодернистский дискурс рассматриваемой проблемы. Активно дискутируемый вопрос в этой области - это замещение национальной идентичностей свободными наднациональными или глобальными идентичностями в эпоху «постмодернизма».

Что будет представлять собой наднациональная идентичность? Каково будет сознание людей, идентифицирующих себя с наднациональным сообществом? Принимая во внимание возможность создания и существования наднациональных идентичностей, хочется надеяться, что они не могут быть замещены космополитической культурой или потерей этнокультурной и национальной идентичностей.

Подводя промежуточный вывод, отметим, что наиболее эффективным является исследование идентичности в рамках современной науки, что позволяет открыть новые смыслы и характеристики культурно-идентификационных процессов в регионе, а также 
понять и объяснить соотношение российской национальной (гражданской) и этнической идентичностей. Это очень важно теоретически и практически.

Рассматривая проблему идентичности в полиэтничном регионе именно в ракурсе принадлежности к гражданской идентичности, которая является самой универсальной формой объединения населения любого государства, отметим, что в России гражданство пока не выполняет свою функцию в полной мере. Исследования указывают на то, что российская идентичность не стала доминирующей. Например, все еще имеет место непонимание соотношения российской и этнической идентичностей, т. е. их зачастую противопоставляют.

Этнокультурная идентификация адыгов. Одним из факторов, усложняющих понимание смысла российской национальной идентичности и ее принятия, является негативное отношение к «неудобному этническому фактору», «проблемной» этнической идентичности. Попытаемся понять эту мысль, обратившись к адыгам, в частности к адыгскому этносу. Это представляется важным и по той причине, что в последнее время в нашем отечестве формируется стереотип мышления, будто адыги представляют собой некую опасность для России: «они опасны для подрыва единства и целостности российского государства». Остановимся на двух аргументах, опровергающих этот тезис.

А) Политическая обстановка в регионе вынуждала адыгов в течение многих веков вести оборонительные войны. В результате Кавказской войны большая часть их была уничтожена, сотни тысяч эмигрировали, на исторической родине осталась лишь двадцатая часть населения. Более того, единый народ - адыгейцы, кабардинцы и черкесы - территориально был разделен.

Вот почему адыгейцы составляют ныне лишь четвертую часть населения Республики Адыгея. Это не вина адыгского или русского этноса. Это результат той политики, которая проводилась в этом регионе. Между тем, количественное (процентное) противопоставление этносов работало не на объединение, а на их противопоставление (это явственно проявлялось в среде «политической конъюнктуры»), когда ситуацию упрощали, характеризуя словами «большинство» и «меньшинство». 
В последние годы наметилась тенденция к культурно-историческому развитию духовного единства адыгейцев, кабардинцев и черкесов. Это должно способствовать развитию этнокультурной идентичности адыгов в социокультурном пространстве России, а не сводиться к созданию объединенного государственно-политического образования (Большой Черкесии). К сожалению, на последнем аргументе «играют» многие энонационалисты и так называемые «научные эксперты».

Б) Адыги, которые были изгнаны в XIX веке со своей исторической родины, проживают ныне в 45 странах мира. В последние два десятилетия активизируется сотрудничество зарубежных адыгов с исторической родиной. Общение со многими адыгами в Германии, Турции и Иордании позволяет сделать следующие выводы.

Что касается этнокультурной идентичности, представляется возможным говорить, что в адыгских диаспорных общинах вырисовывается новая идентичность зарубежного адыга (турецкого, иорданского, германского и т.д.). Это адыги с адыгским менталитетом: Адыгея для них духовная родина, где полноценно развивается адыгейская культура и язык. В то же время страна проживания для них становится родиной, потому что они кровно связаны с природной аурой, перенимают некоторые особенности местной материальной и духовной культуры, т.е. то, что созвучно их менталитету. Одним словом, более точным представляется говорить о формировании новой идентичности у адыгов за рубежом: адыг, проживающий за пределами исторической родины.

Преломляя проблему идентификации зарубежных адыгов в политическую плоскость, следует сказать, что нет смысла даже думать о массовом возвращении адыгов на историческую родину, и будто начнут расшатывать и/или подрывать единство российского государства. Такого источника опасности в нашей стране нет.

Известно, что в условиях модернизации России востребованным становится совершенствование миграционной политики; приоритетом здесь остается привлечение из-за рубежа наших соотечественников, т.е. квалифицированной миграции.

В поисках адекватных ответов на вызовы современности, связанных с будущей судьбой не только адыгского этноса, но и всего российского Северного Кавказа, следует отметить важную роль исторической памяти. Говоря словами крупнейшего социолога Европы 3. Баумана, «мы должны помнить - но что?» И для чего помнить? Для 
созидания! Чтобы понять, какое общество возникло из истории, и каковы мы, составляющие это общество? Научили ли нас уроки истории сохранить человеческое в себе, живя в условиях кардинальной переоценки отношения ко многим вопросам человеческого бытия?

Безусловно, память священна. Памятуя о прошлом, исторических корнях своего этноса, проявляя уважение к исторической памяти, важно соотносить с современностью, преодолевая крайности, вызванные либо политической конъюнктурой, либо чрезмерной идеологизацией по отношению к памяти. Время сведения счетов друг с другом и со временем прошло. Необходимо вступить с прошлым в диалог, в новый диалог, подчинив историческую память формированию гражданинапатриота, знающего историю своей страны, своей земли, своего этноса. Рассматривая Адыгею и адыгов в российском культурно-идентификационном пространстве, следует подчеркнуть, что и русский этнос имеет много проблем.

Представляется, что трансформация социокультурного статуса русских в России, в частности и на Северном Кавказе, может стать предметом особого научного и практического интереса. Учитывая русский фактор и наличие проблемы, нами рассматривались некоторые сюжеты русского вопроса [6].

Важно понять, что «не существует опасных народов, существуют лишь опасные ситуации, которые не являются результатом проявления законов природы или истории, или же национального характера, но вытекают из политических условий» (И. Бурума). Добавим от себя, политических условий, создаваемых самими политиками.

В полиэтничной Адыгее издавна проживают и по праву считают себя коренным населением представители более чем 100 этносов. Перспектива развития Адыгеи требует использования конструктивного потенциала этнического фактора, лучших традиционных ценностей всех этносов, которые приобрели общие социокультурные ценности в результате совместной жизни. Это может способствовать сохранению полиэтничности и гражданского мира. Мудрость понимания этой непростой истины позволит выйти на новый уровень бытия, откроет путь к новому модусу идентичности - российской [7].

Представляется, что в целях сохранения гражданского мира в Адыгее, сохранения и укрепления единства полиэтничного российского общества в науке и 
политике следует избегать эмоциональных оценок; изучая общественное мнение, не противопоставлять друг другу этносы своими провокационными вопросами. Понимание экспертами обсуждаемых проблем определяется используемыми способами изложения. Думается, что за дальнейшую судьбу нашего общего российского дома в ответе не только практики-политики, но и ученые, чье слово может играть как созидательную, так и разрушительную силу. По-видимому, исследовательская культура должна обучить людей вести новый диалог человека с человеком и нести гражданскую ответственность за целостность российского Северного Кавказа и в целом России.

Важным представляется и понимание специфики модернизирующегося полиэтничного региона. Осмысление поставленного вопроса связано с ключевым понятием «система», которая включает в себя наряду с другими подсистемами этносы, этнические культуры, этнические традиции, этнокультурные идентичности и т.д. В саморазвивающихся системах, каковой является и социокультурное пространство, формируются особые информационные структуры-коды, фиксирующие важные для целостности системы особенности ее взаимодействия со средой («опыт» предшествующих взаимодействий). Эти информационные структуры-коды являются важным компонентом и определяют способы воспроизводимости системы как целого (B.C. Степин). В современной науке получило признание, что такими информационными структурами в социальных системах являются культура и ее базисные ценности.

Исследование современных культурно-идентификационных процессов в Северо-Кавказском регионе позволило нам разработать концепцию модернизации северокавказского региона, основанную на общих ментальных и социокультурных ценностях северокавказских этносов, а также цивилизационных основаниях полиэтничного сообщества. Эксплицированные концепты «Этничность» и «социокультурное разнообразие», являющиеся ядром построенной концепции, позволяют понять и постичь смысл модернизирующегося традиционного социума и определить векторы его развития.

Среди раскрытых новых признаков и характеристик изучаемого объекта Северо-Кавказского региона, наиболее важным является то, что этническая культура (этничность) в регионе стала системообразующей формой социальной общности. Через 
эту форму происходили генерирование и транслирование социального опыта, накапливавшегося внутри макросоциальной общности людей. Такое понимание этнической культуры позволило впервые преодолеть собирательно-описательное объяснение социокультурных, в частности этнокультурных, реалий Северного Кавказа и дало их новое концептуальное содержание.

Как отмечалось выше, высокий социальный статус этничности сохраняется и в наше время, что находит отражение в самосознании народов северокавказского сообщества и определяет специфику региона. Проецируя этнический феномен в плоскость культуры, нами выявлен его ценностный потенциал, формирующий своеобразную мировоззренческую парадигму.

В условиях динамичного взаимодействия традиционных и инновационных ценностей этническая самоидентификация становится объективной потребностью отдельных индивидов, социальных групп и общностей. Взаимодействие ценностей разных типов и социальных моделей во многом определяет характер и направление развития модернизационных процессов в поликультурном регионе.

Здесь важно понимание соотношения традиций и инноваций и процесса взаимодействия этнических культур в традиционном обществе в условиях модернизации. Традиция, обновляясь, становится источником развития. Инновация утверждает себя через культуру. Это определяет место и роль традиции в модернизирующемся обществе, а в полиэтничном социуме - этнокультурных традиций и идентичностей [8].

Сегодня не следует рассматривать традиции как тормоз модернизации (хотя в современной России отношение к ним отличается амбивалентностью и многоаспектностью). Согласимся с А.Б. Гофманом, отмечающим, что в настоящее время, в связи с процессами глобализации, информатизации, развития средств коммуникации, расширяется диапазон отбираемых и актуализируемых традиционных культурных образцов различных обществ. Традиции и инновации сегодня образуют неразрывное единство: они превращаются друг в друга и не могут существовать друг без друга, так же как без культурных заимствований, диффузии, моды, туризма, самых разных форм глобализации и информатизации. И важно отметить, что индивиды и 
социальные акторы сегодня выбирают не только свое настоящее, не только свое будущее, но и прошлое [9].

Модернизационный путь развития России должен позволить ее регионам опираться на лучшие традиции, созвучные современности. Это значит, что модернизирующееся традиционное общество не только может эффективно развивать свои культурные ценности, но и использовать их как фактор социальной стабильности, экономического и политического развития.

Говоря о перспективе культурных традиций в современных условиях, следует отметить, что этническое самосознание трудно поддается трансформации. Корни этнического самосознания изменяются медленно, особенно эталоны культурной самобытности. Они исторически формировались у каждого этноса, по ним определяют свою этнокультурную идентичность. Именно этнокультурные ценности формируют первоначально мировоззрение человека, его миропонимание. Существует ведь концептуальная разница в мироощущении и миропонимании кавказца и западного человека. Поэтому представляется важным поиск креативности в пространстве традиций и инноваций, а также решения проблемы сохранения этнокультурного разнообразия и совмещения разных видов идентичностей.

Подведем некоторые итоги. Идентификацию этносов, в частности адыгов, необходимо рассматривать с учетом социокультурных условий, в которых она формируется; для нашего исследования - это социокультурное пространство российского Северо-Кавказского региона. Процесс самоидентификации открыт не только национальному, но и глобализирующемуся миру; человек готов вобрать в себя множество идентичностей. В сложную российскую национальную идентичность и глобализирующийся мир он вступает со своим этническим, но в модифицированном виде. Это естественный процесс. Из его менталитета нельзя вырвать какую-то часть искусственно (также нельзя насильственно конструировать), скажем, этническую культуру, историю, традицию и т.д. То есть нельзя вырвать то, что должно быть интегрировано в целое - российскую идентичность. Выпадение этнокультурного компонента из сложной системы (российской идентичности) может повлечь за собой неустойчивость системы. 
Что касается адыгского этноса, то свое существование и дальнейшее развитие, безусловно, он связывает только с Россией, только в составе российской гражданской нации, только в социокультурном пространстве России. Адыгский этнос понимает, что существование и сосуществование, сотрудничество и взаимопонимание возможны лишь на основе диалогических взаимоотношений.

Действительно, в современных условиях диалог выводит на новый уровень осмысления нашего бытия: существование «другого» рядом и взаимодействие с ним неизбежно. Научиться способствовать диалогу, а не отчуждению и уничтожению, открыть себя «другому» и принять «другого» в процессах взаимодействия на любом уровне важно и нужно для выживания. В этом и смысл общенациональной российской идентичности. В этом мне видится и смысл национальной программы развития нашей страны.

Рассматривая идентичность как сложную открытую систему, следует подчеркнуть, что разные виды идентичности не исключают друг друга, а сосуществуют и взаимодействуют друг с другом. Говоря о совмещении/интеграции разных видов идентичности, мы не имеем в виду воспроизводство этнической идентичности в ущерб российской; нами предпринимается попытка понимания эвристического смысла и ценности российской идентичности, понимания ее возможностей для российских этносов и ее регионов.

Российская идентичность вбирает в себя множество этнокультурных, религиозных и региональных идентичностей. Говоря об укреплении российской идентичности («российскости») на практике, важно ставить вопрос о взаимопонимании и сотрудничестве на основе диалога в условиях формирующейся новой социокультурной реальности. Отсюда - понимание смысла единства российского общества.

Для понимания смысла самоорганизации полиэтничного российского общества, смысла возрастающей сложности этого процесса необходим диалог ученых, политиков и народа. Представляется, что мы своим словом и делом обязаны помочь обустройству нашего российского дома, чтобы у каждого из нас было желание жить в нем. 


\section{Литература:}

1. Бауман 3. Индивидуализированное общество / Пер. с англ. под ред. В.Л. Иноземцева. М., 2002. С. 192.

2. Астафьева О.Н. Постнеклассические практики позиционирования в современном социокультурном дискурсе // Постнеклассические практики и социокультурные трансформации / Под общ. Ред. О.Н. Астафьевой. М., 2009. С.109-124.

3. Шадже А.Ю., Жаде З.А., Куква Е.С. Возможности синергетического подхода в исследовании региональных этносоциальных процессов // Вестник Калмыцкого университета. 2016. № 1. С. 120-126.

4. Делокаров К., Шадже А., Чефранов С., Куква Е. Моделирование российской идентичности на Северном Кавказе: синергетико-ценологический подход // Управление мегаполисом. М., 2012. №5. С. 53-58.

5. Каган М.С. Синергетическая парадигма - диалектика общего и особенного в методологии познания разных сфер бытия // Синергетическая парадигма. Нелинейное мышление в науке и искусстве. М., 2002. С. 40, 45.

6. Шадже А.Ю. Интегрирующая роль русского народа. Русский вопрос // Волков Ю.Г., Хунагов Р.Д., Шадже А.Ю. Гуманизм и полиэтническая Россия. Майкоп, 2001. С.131-143.

7. Ханаху Р.А. Традиционная культура Северного Кавказа: вызовы времени (социально-философский анализ). Майкоп, 1997; Мир культуры адыгов (проблемы эволюции и целостности) / Под ред Р.А. Ханаху. Майкоп, 2002.

8. Ханаху Р.А. Малые культуры в условиях глобальных измененийв мире//Философия. Социология. Культурология. Майкоп.2006. №5. С.152.

9. Гофман А.Б. В поисках утраченной идентичности: традиции, традиционализм и национальная идентичность // Вопросы социальной теории: Научный альманах. 2010. Том IV. Человек в поисках идентичности / Под ред. Ю.М. Резника и М.В. Тлостановой. М., 2010. С.243. 
Калашаова Д.А.

\title{
Социоэтнокультурный феномен традиционной свадебной обрядности адыгов
}

\begin{abstract}
Аннотация: В данной статье исследуется специфика свадебной обрядности адьгов, определяемая этническими особенностями адьгского этноса. Автор обращает внимание на свадьбу как своеобразное творчество народа, в котором отразились хозяйственная, сочиальная, провавая религиозно-магическая и другие сторонь его жизни.

Ключевые слова: адыги, брак, брачный ритуал, кальым, сватовство, невеста, жених, аталькк.
\end{abstract}

Традиционная адыгская свадьба, как и другие народные обряды, выступала в своем синкретическом единстве и представляла собой цельное зрелище, то есть жестко регламентированный комплекс действий, имеющих строго заданную последовательность и включающий в себя пляски, атлетические и конные состязания, конкурсы и пиры.

Исследование свадебной обрядности адыгов актуально, так как позволяет лучше представить, чем жил народ и какова динамика свадебной обрядности. Свадебные обряды и обычаи, в которых сконцентрированы многие элементы духовной культуры народа, занимают в истории культуры и во всей жизни адыгского общества особое место.

Свадебная обрядность представляет собой обширный цикл обрядов, начальным звеном которых правильнее всего считается сватовство.

Следующим звеном является «нысаще» - это вывоз невесты из отчего дома.

Третьим звеном по праву считается размещение жениха и невесты в «чужих домах».

Четвертым звеном - привоз невесты в дом жениха - «унеише».

Пятым - размещение невесты в брачной комнате «лъэгъунэ».

Шестым - непосредственно «джегу».

Седьмым - «уход бабушки».

Восьмым - ввод невесты в дом свекрови.

Девятым обрядом - посещение невесткой своих родителей. 
Начальный элемент традиционного цикла свадебных обрядов, характерный как для других народов, так и для адыгов, - сватовство.

Сватовство у адыгов в конце XIX века проходило по соглашению между родителями жениха и невесты, но это не являлось общим правилом. В трудах Г.Ю. Клапрота, Тэбу де Мариньи, Ж-Ш де Беса, И.Ф. Бламберга, Дюбуа де Монпере, Дж. Бэла и других зарубежных авторов находим сведения об отношениях внутри адыгской семьи, формах заключения брака, в том числе и о брачном выкупе. Однако это звено свадебного цикла имеет особенности, не характерные для других народов: у адыгов наряду с браком по сговору существовала и другая форма брака - это похищение невест, или умыкание. Описание брака путем умыкания имеется в трудах С. Хан-Гирея и Ш.Б. Ногмова, но они пишут, что умыкание не является главной формой заключения брака. Я.С. Смирнова выделила три разных вида умыкания невесты: «действительно насильственное похищение, похищение с согласия девушки и фиктивное похищение». В первом случае причиной умыкания было несогласие девушки и ее родителей на брак. Во втором - нежелание родителей невесты считаться с ее желанием; в третьем избавление обеих сторон от части свадебных расходов. Нужно отметить, что второй вид брака позднее вытеснил первый.

Второй элемент свадебного обряда адыгов - обряд «нысаще» - начинается с увоза невесты из ее родительского дома в дом жениха. Суть обряда заключается в том, что жених с друзьями забирает невесту в свой дом.

Жених при этом должен был соблюдать обычай избегания - не встречаться со своими родственниками и родственниками невесты.

Помещение молодой в «чужом доме». Этот обряд считался одним из центральных элементов свадебной обрядности адыгов и являлся специфичным для традиционной адыгской свадьбы.

Причин помещения невесты в «чужом доме» было две.

Первая причина: если семья была не готова к свадьбе материально. Вторая причина: установление родственных отношений с состоятельными и влиятельными семьями, с которыми заранее договаривались. 
По времени невеста находилась в «чужом доме» от двух недель до двух лет. Брак оформлялся в «чужом доме» с помощью религиозного обряда бракосочетания «нЭЧыхь».

Адыги новобрачного тоже помещали в «чужой дом», куда он уходил сразу после прибытия свадебного кортежа к своему аулу. Жених соблюдал обычай избегания по отношению к родителям, старшим родственникам и даже соседям. Он поселялся или в доме своего родственника, или друга. Хозяин дома становился его аталыком, а он воспитанником. Теперь не только семья «чужого дома» считала его своим близким родственником, но и все члены его рода. Нужно отметить, что браки между семьями новобрачного и аталыка были строго запрещены. Жених мог находиться в доме своего аталыка месяц и более. Когда подходило время ухода жениха в родной дом, аталык заранее сообщал его родителям о дне его привоза. Н. Меретуков пишет: «В такой - то день привезёт к ним обратно их блудного сына» [1]. Аталык в честь увоза новобрачного устраивал празднество с пиршеством и танцами. Эта церемония называлась «шэощэжь», т.е. возвращение воспитанника. Новобрачный даже после возвращения в родной дом должен был соблюдать обычай избегания по отношению к своим родителям и старшим родственникам. Необходимо отметить, что этот элемент свадебного обряда является специфичным, характерным именно для традиционной адыгской свадьбы.

4) Следующим циклом свадебного обряда является размещение невесты в брачной комнате «лэгъунэ». Адыги в прошлом строили для молодоженов специальные помещения. В.В.Васильков писал, что невесту поселяли в особо сооруженную для молодоженов саклю.

В брачной комнате новобрачная не имела права заниматься шитьем и даже прикасаться к иголке с ниткой, пока не совершался специальный праздничный обряд, посвященный шитью, который назывался «дынхэу».

Адыгский народ считал: умение шить являлось одним из основных достоинств адыгской женщины. Выбирая невесту, жених всегда обращал на это внимание. Девушке, которая не умела шить, не было никаких шансов выйти замуж. Поэтому обряд «дынхэу» играл большую роль в традиционной свадебной обрядности адыгов.

5) Кульминационным звеном свадебного обряда являлось свадебное празднество «джэгу». Заранее объявлялся день свадьбы. По поручению хозяина дома обходили весь 
аул и приглашали всех людей на торжество. В соседние аулы к родственникам и знакомым посылали гонцов. В день свадьбы вывешивался флаг на крыше дома. На свадьбу приходили не только все жители аула, для которых она являлась праздником, но и приезжали из других аулов и даже из Кабарды и Черкесии. На адыгскую свадьбу мог прийти любой человек, даже незнакомый. Адыги с большим радушием и с присущим им гостеприимством встречали всякого, кто приходил на торжество [2].

Свадьба проходила от двух до десяти дней у состоятельных семей. В бедных семьях празднество проходило всего один день. Адыгские свадьбы всегда сопровождались различными скачками, джигитовкой, стрельбой в цель и т. п. Главным действующим лицом на свадьбе был «джегуако». Т. Лапинский о «джегуако» писал: «Этих патриархальных певцов и почитают и боятся. Каждое хорошее или дурное дело, мужество или трусость, себялюбие или самопожертвование, гостеприимство или скупость, красота и любовь - находят в них своих хвалителей или беспощадных сатириков» [3].

Завершением каждой адыгской свадьбы являлся хороводный танец «джегухъурай», который объявлял «джегуако», стоя в свадебном кругу.

Этот танец могли танцевать только юноши, старики и девушки. Завершающий танец на свадьбе имел культовое значение [4].

К важным церемониям свадьбы относится обряд ухода бабушки жениха из дома, который предшествует обряду ввода невестки в большой дом. После завершения свадьбы новобрачную подводили к порогу большого дома, оттуда выбегала бабушка и кричала, обращаясь к окружающим, что невестка выгнала ее из дома, который по праву принадлежит ей. Получив подарки от родственников и новобрачной, бабушка поворачивала назад и попадала в объятия молодой, та молча кланялась и давала ей понять, что старуха еще нужна в доме, что ее мудрость и старость будут почитаемы. Только тогда бабушка возвращалась назад. Основой обряда является уважение старости, которое было поставлено у адыгов на высокую степень нравственной культуры.

6) Следующим важным обрядом в традиционной свадебной церемонии адыгов являлся ввод невестки в большой дом. 
7) Последним, завершающим обрядовый цикл свадебного ритуала является посещение невесткой после свадьбы дома своих родителей - «тыщас». Только по истечении одного года и более новобрачная могла посетить дом своих родителей. По сообщению А.М. Ладыженского, «...после свадьбы черкешенка посещала всех своих кровных родственников, которые спрашивали у неё, в чём она и её (с мужем) хозяйство нуждается, затем не только родители, но и дяди и другие одаривали скотом и домашними вещами» [5, с. 224-239].

Анализ традиционной свадебной обрядности адыгов дает возможность увидеть, что наряду с патриархальными традициями в них достаточно много прогрессивных народных традиций, которым можно отнести формы нравственных отношений, взаимное уважение, коллективизм.

В период кризисного состояния современного социума традиционная свадебная обрядность трансформируется, некоторые обряды перемешались между собой, потеряв своё функциональное первоначальное значение. В трансформированном виде многие из этих обрядов и игр получили новую аранжировку и в современном быту в основном пользуются как средства декорирования традиционной национальной свадьбы.

\section{Литература:}

1.Ногмов Ш. Б. История адыгейского народа. - Нальчик: Эльбрус, 1982.

2.Хан - Гирей С. Записки о Черкесии. Вст. статья и подготовка текста к печати

В.К. Гарданова и Г.Х. Мамбетова. - Нальчик: Эльбрус, 1978. -333с.

3.Меретуков Н. Введение в историю адыгов. - Казань, 1912 (перевод с арабск.)

Рукопись, архив АГИГИ, ф.1, папка 189, д. 19. - 46с.

4.Васильков В.В.Очерки быта темиргоевцев. // СМОМПК, 1901. - Вып. ХХІХ. - 80 с.

5.Ладыженский А.М. Обычное семейное право черкес // Новый Восток, 1928. - № 22. 
Нехай В. Н., Шаов А. А.

\section{Этносоциальные процессы на Юге России}

в условиях нарастания социокультурной напряженности

Аннотация: B статье рассматривается спеиифика этносоциальных прочессов в поликультурном пространстве Юга России. Отмечается, что глобализация в своей унификационной вариации порождает новые вызовы цивилизационной уникальности Северного Кавказа, которые создают рискогенную среду для сохранения этнокультурной идентичности народов рассматриваемого региона.

Ключевые слова: этносочиальные процессы, Юг России, глобализация, социокультурная напряженность, социионормативные институциии

В современом глобализирующемся мире, стирающим грани между реальным и виртуальным бытием, проблема поиска символических смыслов человеческого существования обретает особое значение. Дело в том, что в лоне прагматической рациональности человеческая натура теряет свою высокоинтимную связь с миром культурно-исторических архетипов, которые сформировали цельную природу человека. Ускорение социального времени и искажение социального пространства деформирует диалектическую взаимосвязь рационального и чувственного начал в духовном мире человека, в результате чего концепты рациональности неотвратимо выдавливают чувственные протоформы человеческого сознания, воплощенные в сакральных смыслах традиционной культуры. В подобных условиях человечество постепенно попадает в моральное гетто разума, который рутинизирует приглаженные образцы утилитарно-гедонистических практик и выталкивает их на авансцену меркантильного существования. Отныне в авангарде оказываются рафинированные принципы западноевропейской культуры, открыто демонстрирующие передовые достижения цивилизации и социального прогресса, которые возводятся в полный абсолют.

К их числу можно отнести капиталистическую модель мирохозяйствования и протестантскую этику западноевропейского человека, которые в совокупности формируют кредо деловой и успешной личности и усиливают ее экспансионистские устремления вдоль контуров всего планетарного континуума. Казалось бы, практический смысл этого понятен и потому очень прост: победа рациональности над всеми формами архаического мировоззрения - мифом, религией и т.д., что в конечном 
итоге должно ослабить оковы морального гнета примитивности традиционного общества и даровать человечеству универсальное право на неограниченный социальный прогресс. Однако насильственная имплантация чужеродных элементов западной культуры (а сейчас и массовой культуры) в форсированном формате не интегрирует Запад с остальным миром, а, напротив, акселерирует резистентность институтов традиционной культуры за пределами западной цивилизации. При этом любые попытки остановить капсулирование традиционных культур от цивилизационных «прелестей» Модерна в его западноевропейской вариации вызывают ожесточенное сопротивление и провоцируют социальные протесты по всему миру [1].

Причем, указанная протестность реализуется в трех ипостасях: антиглобализме, консерватизме и изоляционизме. Первая продуцируется в рамках самого западного мира и проявляется как внутренняя реакция на радикальную унификацию социального пространства. Вторая предполагает резкий разворот к ценностям традиционного общества при одновременной реконструкции традиционных институций, которые усиливают артикуляцию на идентификационной матрице домодерного бытия.

Третья ипостась предполагает замыкание на культурных ценностях традиционного общества и напрочь пресекает любые контакты с внешней модерновой средой, превращая инокультурные элементы в систему табу.

В этих сложных условиях и разворачивается процесс дальнейшего этносоциального развития. Временная и пространственная унитаризация данных ипостасей в эволюции духовной жизни человечества возможна лишь гипотетически, что, конечно же, расширяет питательную среду глобализации. Однако в действительности, образуя многочисленные вариации, антиглобализм, консерватизм и изоляционизм в разнообразных формах запускают систему самоочистки этнокультуры, которая начинает гасить флуктуационные колебания в этносреде, и тем самым, индуцировать традицию как инвариантный нарратив дальнейшего этнокультурного развития. Такой сценарий этносоциальной эволюции имеет две стороны медали: с одной стороны, он усиливает этническое самосознание и реанимирует традиционную этноинституцию, реинсталлируя в современную жизнь этноса воспринимаемые сторонниками модерна архаические формы бытия (мифологию, религию, традицию и т.д.). Но, с другой стороны, усиление этноцентризма как доминантной идеологии ЭТНОФИАОСОФИЯ АДЫГОВ: ОТ МИФА К АОГОСУ : 
выводит данную этническую единицу из партнерского дискурса цивилизованного человечества и неизбежно дистанцирует ее от материальных и духовных благ современной цивилизации. И поскольку модерн провозглашает материальную, финансово-экономическую систему с ее громадной совокупностью социальных лифтов жупелом, а порой и венцом человеческого прогресса, то не трудно представить, какими последствиями для капсулирующегося этноса или даже государства может обернуться выбор подобного сценария. Ярким примером радикальной имплементации принципов традиционного общества с их редукцией к социалистической доктрине является северокорейское государство, которое благодаря усилению воинственной риторики, приправленной ядерными мускулами и пропитанной антикапиталистическим содержанием идеологией чучхе, за несколько десятилетий превратилось в очевидного лузера в глазах международного сообщества.

На фоне этого, Южная Корея, которая органично вписалась в систему рыночных отношений и демонстративно «распахнула калитку» адептам экономической глобализации, воспринимается в цивилизованном мире как союзник, партнер и даже как одна из колыбелей азиатского экономического чуда. При этом, трудно согласиться с тем, что южные корейцы сохранили свою многовековую традиционную соционормативность. Наступающая цивилизация до неузнаваемости изменила не только мирохозяйственную структуру корейского общества, но и урбанизировав свыше 4/5 населения страны, лишила корейцев возможности сохранения традиционных социальных связей и отношений в патриархальном духе. В то же время, формально Южная Корея апеллирует к традиционным ценностям, пропагандируя традиционную одежду, кухню и национальные праздники, и тем самым девальвирует их примордиальный смысл и окончательно погружает культурное наследие корейского народа в пространство масскультурного суррогата.

Южнокорейский социум - весьма показательный пример, демонстрирующий неизбежность выхолащивания традиционных ценностей в случае имплементации аксиономики модерна и глобализации как его пространственного инварианта. Однако в отличие от подавляющего большинства современных социокультурных систем, корейская смогла довольно безболезненно и бесконфликтно интегрировать свою этничность в лоно унификационного пространства Запада и получить огромные бонусы 
в виде технико-технологического и экономического прогресса. Как видно из нашего исторического прошлого, такой сценарий этносоциального развития маловероятен в этнокультурном пространстве северокавказского общества, которое не ставило перед собой цель инкорпорации принципов евромодерна в структуру социокульутрного бытия, да еще в ограниченные двумя десятилетиями сроки.

Напротив, в 1990-е гг. ХХ в. этносоциальные общности получили новый импульс к возрождению своего культурно-исторического наследия. Создание семи северокавказских республик, две из которых (Адыгея и Карачаево-Черкесия) в советский период являлись автономными областями в составе субъектов РСФСР, послужило основанием для укрепления этнического самосознания и гарантировало народам Северного Кавказа право на дальнейшее укрепление своей идентичности в рамках единого российского государства. Разумеется, это вызвало неоднозначные последствия для этнополитического пространства России и, соответственно, неоднозначную реакцию политических сил на процессы суверенизации, как на федеральном, так и на региональном уровнях. Мы не беремся оценивать политическую составляющую процесса федерализации нашей страны, однако с позиции социокультурного развития, северокавказские этносы, включая и малочисленные, получили историческую возможность сохранения базовых элементов своей соционормативности: языка, культуры и системы нравственно-этической системы координат.

Как показывает четвертьвековая практика, у народов Северного Кавказа и Юга России этноидентификационные элементы продемонстрировали жизнестойкость и резистентность инокультурному влиянию. Одним из подтверждений этого является результаты социологического исследования, которое проводилось учеными Адыгейского государственного университета в шести субъектах Юга России и Северного Кавказа в 2015-2016 гг. с выборочной совокупностью $\mathrm{N}=1734$ в рамках проекта РНФ №15-18-00148 «Этносоциальные процессы и межэтническая напряженность на Юге России: совершенствование аналитического инструментария и способов регулирования». Как видно из опроса, респонденты отмечают высокую значимость для них этноидентификационных компонентов. 
Большинство опрошенных, независимо от региона проживания терминализировали значимость этнокультурных элементов, к числу которых относятся родной язык, обычаи и традиции, национальный характер, родная земля, религия, происхождение и общее прошлое. Оценивая их важность в жизни человека по пятибалльной системе (1 - минимальная значимость, 5 - абсолютная значимость), респонденты отметили в качестве наиболее значимого компонента родной язык. Около 68\% опрошенных придают его сохранению первостепенное значение. Причем в Кабардино-Балкарской Республике (КБР) и в Карачаево-Черкесии (КЧР) доля лиц, выступающих за его презервацию, выше, чем в других субъектах РФ, вошедших в выборку, и составляет 72,4\% и 71,8\% соответственно. Самые низкие значения по данному показателю отмечены в Краснодарском крае $(61,9 \%)$, однако эта цифра на Кубани компенсируется наличием 18,3\% респондентов, которые оценили значимость родного языка на 4-х балльном уровне. Показательно, что во всех регионах, доля лиц, отмечающих низкую значимость родного языка для жизни общества, не достигла и $10 \%$. Данная позиция объясняется тем, что население Юга России и Северного Кавказа попрежнему видит перспективу сохранения своей этнической и культурной идентичности через родной язык, а его потерю воспринимает как основание распада культурноидентификационной матрицы. Таким образом, этническая идентичность в сознании респондентов репродуцируется посредством обращения к символикокоммуникативной природе этнокультуры, центральное место в которой занимает именно язык.

Вместе с тем, становится заметно, что при кажущемся разложении этнокультуры под натиском эры модерна и его социальных институций, жители Юга России и Северного Кавказа в своем восприятии декларируют приверженность этническим традициям. Как видно из опроса, 54,5 \% респондентов отметили очень высокую, а 22\% высокую значимость национальных традиций и обычаев в духовной жизни общества. Наибольшее внимание проблеме сохранения традиций придает население КБР (67\%), КЧР (56\%), Ставропольского края (54,3\%) и Адыгеи (56\%), тогда как жители Краснодарского края $(47 \%)$ и Ростовской области $(48,4 \%)$, что свидетельствует о живучести в сознании населения опрошенных регионов этностереотипов, которые реконструируются через систему традиционной нормативности. 
При этом необходимо отметить, что наряду с традициями и обычаями, население Южного федерального округа (ЮФО) и Северокавказского федерального округа (СКФО) выделяет в качестве одной из важнейших характеристик народа национальный характер. Ввиду отсутствия в общественном сознании, равно как и в академической среде единого понимания данного концепта, становится очевидно, что опрошенные вкладывали в него разный смысл. В данной работе мы ставим перед собой задачу не концептуализации понятия «национальный характер», а подтверждения факта высокой символико-интегративной значимости свойств национального характера для северокавказского социума, в жизни которого традиционные институции обретают функциональное совершенство лишь в условиях их диалектического единения с национальным духом. Свыше 2/3 опрошенных оценивают национальный характер как очень важный $(42,1 \%)$ и важный $(25,4 \%)$ компонент этнического бытия. Доля лиц, по мнению которых национальный характер имеет важного значения в их жизни, крайне мала и составляет 4,4\% от числа опрошенных, что, опять же, фиксирует чрезвычайно низкий уровень детерминализированности этничности на Юге России.

Более того, население включенных в выборку регионов сохраняет артикуляцию на социально-исторических компонентах этнического бытия. Так, более половины респондентов отмечают, что происхождение как признак родства играет очень важную $(40,3 \%)$ и важную роль $(19,2 \%)$ в жизни каждого из них. Приблизительно такое же число опрошенных (39,4\% и 19,5\% соответственно) убеждено в том, что общее прошлое усиливает этноидентификационные процессы. Это свидетельствует в пользу того, что историческое пространство для жителей Северного Кавказа сохраняет не только онтологический смысл (например, актуализируется посредством обращения к исторической травме), но и усиливает этноконсолидационный потенциал того или иного народа через сакрализацию культурно-исторических нарративов. Показательно, что даже в высокоурбанизированной среде население Краснодарского края и Ростовской области не дистанцируется от этноисторических компонентов своего культуры и закладывает основания для пролонгации своего этнокультурного бытия в среднесрочной темпоральной перспективе, что показывает довольно высокую эффективность политики региональных властей в вопросе возрождения казачества на Кубани и Дону. 
Рассуждая о перспективах развития своих этносов, жители ЮФО и СКФО связывают их с потребностью сохранения традиционной топики, реконструкцией традиционных соционормативных институций, а также с интеграцией этноса в социально-политические континуум региона. В частности, большинство опрошенных уверены в том, что дальнейшее развитие этноса возможно посредством воспитания молодежи в духе национальных и религиозных традиций и обычаев, а также посредством распространения и широкого употребления родного языка в широком обиходе и в различных социальных институтах. Так считают 36\% и 34,5\% соответственно. При этом полученные ответы во внутрирегиональном измерении значительно расходятся. Если важность воспитания в национальном духе и использования родного языка отмечается в Краснодарском крае (46,6\% и 41,5\% респондентов) и в Кабардино-Балкарии (по 41,6\%), и чуть меньше в Республике Адыгея и Ростовской области, то в КЧР эти показатели значительно ниже и составляют всего $24,1 \%$ и 26,1\% соответственно. Несмотря на такие различия, артикуляция на воспитательной и языковой компонентах очень заметна и обусловлена осознанием их важности в воспроизводстве традиционной системы ценностей и невозможности символико-культурной репрезентации этнической культуры без сохранения языка как ее ядра.

Особое внимание жители Юга России уделяют необходимости объективного освещения исторической судьбы народа. Если в Северокавказских субъектах и Адыгее значения данного ответа колеблются в диапазоне от 13,2\% в КЧР до 19,7\% в РА, то в Ростовской области они достигают 27,2\%, а в Краснодарском крае - 41\%. Это свидетельствует о том, что проблема осуществления корректной, основанной на реальных фактографических данных интерпретации исторических процессов в жизни этноса сопрягается с наличием в прошлом предвзятого или политизированного отношения к судьбоносным, а порой и трагическим вехам истории (Кавказской войны или депортации кубанского казачества). Подобный посыл также сигнализирует о желании избегать и в дальнейшем фальсификации и замалчивания исторических фактов, которые оказали существенное влияние на состояние этноса. В этой связи этносоциальные структуры апеллируют не только к возможности использования культурно-идеологического инструментария в сохранении своего этнического «Я» 
(воспитание, внедрение родного языка и т.д.), но и обращаются к количественным методам, которые сводятся к воздействию на механическое (репатриация) и естественное движение населения (рождаемость).

Как показывают результаты исследования, репатриация для каждого восьмого опрошенного представляется одним из способов восстановления исторической справедливости. Причем если на Ставрополье и в Карачаево-Черкесии этого мнения придерживаются около 5\% респондентов, то в Адыгее и КБР более $10 \%$ опрошенных дальнейшее развитие своих этносов люди связывают с возвращением их соотечественников на историческую родину. На Кубани данную позицию разделяет почти каждый третий житель (29,3\%), что, на наш взгляд, обусловлено стремлением репатриировать не только представителей казачества в Краснодарский край, но и вернуть русскоязычное население, которое в силу исторических обстоятельств оказалось за пределами своей родины.

Таким образом, несмотря на наличие разнообразных форм восприятия этносоциальных процессов, а также поливариантности их развития в обозримой перспективе, население Юга России и Северного Кавказа отмечает высокую значимость этноидентификационных характеристик для духовной жизни каждого регионального социума. При этом особое значение в выстраивании стратегии возрождения культурного пространства имеют исторические события, которые спровоцировали пространственную диссипацию и в отсроченной форме предопределили интенциональную потребность в социокультурной реинтеграции этносов Юга России. Поэтому решение данной проблемы возможно посредством преодоления фундаментального противоречия между аксионормативностью традиционного социума и общества модерна.

\section{Литература:}

1. Ханаху Р.А. Малые культуры в условиях глобальных изменений в мире//Философия. Социология. Культурология. Майкоп.2006. №5. С.153.

2. The United Nations Department of Economic and Social Affairs: Urban Population 2013. Рейтинг урбанизации стран мира [Электронный ресурс]. Режим доступа: http://hdr.undp.org/en 
Жаде 3.А., Хуако 3.Ю.

\title{
Этнос и социокультурная среда функционирования языка
}

\begin{abstract}
Аннотащия: B статье рассматриваются актуальные проблемь создания и совершенствования алфавитов и письменностей, исторические и сочиокультурные аспекты выбора графики письма, условия и возможности функиионирования языка того или иного этноса в социуме, в единой социально-культурной и культурноинформационной среде.

Ключевые слова: этнос, сочиокультурная среда, информащионная ичивилизация, письмена, алфавит, письменность, графика письма, социальная коммуникация, культурно-информационная среда.
\end{abstract}

В современном мире особую актуальность приобретает социокультурная среда функционирования языка, его самочувствие в общественной и политической жизни. Внимательного отношения требует исторически сложившаяся традиция регулирования языковых отношений в многонациональном государстве.

Понадобились столетия, чтобы человек додумался зафиксировать слово посредством печатного станка. По утверждению авторитетных ученых, «первое и главное произведение словесности есть самое слово, язык народа».

«Слово, - замечает выдающийся русский историк В.О. Ключевский, - не случайная комбинация звуков, не условный знак для выражения мысли, а творческое дело народного духа, это художественный образ, в котором запечатлелось наблюдение народа над самим собой и над окружающим миром» [1]. В отсутствие печатного слова, письменности появляются разнообразные жанры словесного творчества народа: краткие изречения, заговоры, пословицы, поговорки, клятвы, загадки, приметы, притчи, песни, сказки и прочее. Таким образом, из поколения в поколение передается и сохраняется историческая память.

C незапамятных времен в мифотворчестве этносов утвердились предшествовавшие печатному (письменному) слову письмена - графические элементы в виде идеограммов (рисунки, иероглифы), клинописные знаки, буквы, разновидные графемы, служившие целям сообщения, передачи информации, новости. Многие письмена оставались и остаются до сих пор нерасшифрованными, однако это не мешает 
быть им «элементами мифопоэтической системы, считаться и почитаться священными, использоваться в магической и ритуальной практике и т. п.».

На пути человека к самосовершенствованию и рациональному самопознанию письмена прошли этапы «предметного» (бирки, знаки собственности, жезлы вестников, кипу, пояса вампум с нанизанными раковинами) и «рисуночного» (пиктограммы) принципов письма, стремясь «превратиться в некую самодостаточную имманентную систему типа алфавита». Каждый значимый шаг в интересах «прогресса письменности был связан с тем, что система письмен становилась все более герметичной, все менее наглядной для неискушенного, непрофессионального пользователя» [2].

Введение, каждое существенное усовершенствование системы письмен давали «исключительный эффект в решении проблемы памяти, столь важной для мифопоэтической эпохи». Это обстоятельство, в свою очередь, способствовало усилению роли и повышению престижа письмен, приводило к их сакрализации, обожествлению, священности. Знание, изобретение письмен, пользование ими становилось уделом особого разряда жрецов (кельтские друиды, египетские «священнокнижники») или приравненных в конечном счете к ним довольно изолированных профессиональных писцов.

Божественное происхождение письмен признается и в исламе, ибо аллах создал буквы и сообщил об этом Адаму. Соответственно алфавит становится мощной классификационной системой, в которой, во-первых, каждый элемент (буква) связан с другим, во-вторых, он сопоставлен с неким утверждением, формулой, сакральной ценностью, аббревиатурой которой он является, в-третьих, он соотнесен с другими «смыслами-классификаторами». В этих условиях изобретатели алфавита как «родоначальники культурной традиции пользовались особым уважением, нередко считались святыми». Более последовательным становится продолжение «жреческой традиции изобретения письмен и заботы о письме, о священных текстах, о книге» [2].

В двадцатом веке с развитием информационной цивилизации, с учетом опыта предшествующих поколений ученые попытались обозначить этапы (периоды) становления и развития социальной коммуникации. Здесь преуспел канадский социолог и культуролог Герберт Маклуэн, основные подходы которого разделяют философ и социолог В.И. Курбатов и другие. В данном случае суждения Герберта Маклуэна и В.И. 
Курбатова затрагивают, прежде всего, информационную цивилизацию, развитие культуры в современном мире, преобразование средств массовой коммуникации, в основе которой письменное слово. Выводы касаются изменений средств массовой коммуникации - начиная с устной речи во времена жизни племен, письменной коммуникации и активизации человеческой визуальности в период изобретения книгопечатания и кончая созданием электронными средствами массовой коммуникации особого состояния «всесторонней сопричастности к глобальному социальному миру».

Итак, Герберт Маклуэн придерживается «трехступенчатой модели всемирной истории». На наш взгляд, скорее всего речь идет о периодизации истории становления и совершенствования информационной цивилизации, социальной коммуникации. 1-я эпоха - человек слушающий, т. е. эпоха племенного индивида с преобладанием устной речи в качестве коммуникации в акустическом (доалфавитном) мире, где преобладает мифологическое сознание. 2-я эпоха - человек смотрящий. Она связана с появлением типографского дела (печатный станок И. Гутенберга) или индустриального индивида при преобладании в коммуникации печатного (письменного) слова над устной речью. В данную эпоху изобретение алфавита означало переход к новой эре. Воспринимаемая глазом строка стала началом новой организации людей, думающих логически и последовательно (рационалистическое сознание). 3-я эпоха - человек слушающий и смотрящий. Это период «информационного индивида в условиях победы электронной (аудиовизуальной) коммуникации, повышающей интеллектуальные способности и творческий характер личности (синтез мифорационалистического сознания) [3].

В процессе развития устной речи, создания алфавита, письменности, книгопечатания язык выступает как важнейшая информационно-знаковая система человеческого общества. Возникновение, функционирование и распространение знания в обществе невозможно без печатного (письменного) слова, без общения, выражаясь словами Фридриха Ницше, «через письма и книги».

Сложным и противоречивым в царской России и в первые годы после революции 1917 года был выбор графической основы алфавитов на языках народов, ранее не имевших своей письменности. Если говорить о северокавказских народах, то они начали пользоваться письменным (печатным) словом после европейцев спустя четыре 
столетия. Особенно в послереволюционный период спешно взялись за разработку алфавитов на языках бесписьменных народов и достигли очевидных успехов. Только в первой половине двадцатого века более пятидесяти национальностей России приобрели письменность на родных языках. Это было значимым достижением отечественного языкознания.

В Адыгее, как и в других автономиях Северного Кавказа, при создании письменности сначала приняли за основу арабскую графику. Нам представляется, что в данном случае существенную роль сыграл религиозный фактор. Затем за основу письменности была взята латинская графика.

К середине двадцатых годов прошлого столетия свои письменности на арабском алфавите получили аварцы, адыгейцы, даргинцы, ингуши, кабардинцы, лакцы, лезгины, черкесы и чеченцы. Вслед за ними тюркоязычные народности Северного Кавказа (балкарцы, карачаевцы) разработали письменности, но на латинице. Латинизированной основе письма отдали предпочтение таты, табасаранцы, ногайцы, а также абазинцы. Этому способствовало создание в прежнем Советском Союзе Центрального комитета нового тюркского алфавита, вскоре получившего другое название - Всесоюзный центральный комитет нового алфавита при ЦИК СССР.

Двуязычие, многоязычие народностей и этнических групп на Северном Кавказе и в других регионах России, испокон веков говоривших и говорящих на десятках языков, всегда ставило перед необходимостью практического обращения к единому языку общения. В условиях формирования общей для полиэтнического населения социокультуроной среды языком межнационального общения в нашей стране, естественно, становится русский язык. Двуязычие и многоязычие, с учетом конкретноисторических и социально-культурных факторов, оптимальных условий использования русского языка как государственного языка Российской Федерации, языка межнационального общения, воспринимается как объективная реальность. Таким образом, закономерным шагом стал перевод письменности бесписьменных (младописьменных) на кириллицу в 30-е годы ХХ века в едином социокультурном пространстве России.

Сегодня Российская Федерация - крупнейшее многонациональное (полиэтническое) государство мира. По данным переписи 2010 года, в нем проживают эТНОФИАОСОФНЯ АДЫГОВ: ОТ МИФА К АОГОСУ : 
представители 193 национальностей. В Российской Федерации используются 277 языков и диалектов, в государственной системе образования функционируют 89 языков, 30 из них - в качестве языка обучения, 59 - как предмет изучения. Выбор кириллического письма в качестве графической основы алфавитов на языках всех национальностей России продиктован объединяющей ролью русского народа, многовековым межкультурным и межэтническим взаимодействием, сформировавшимся уникальным культурным многообразием и духовной общностью различных народов страны[4]. В Стратегии государственной национальной политики Российской Федерации на период до 2025 года отмечается, что «современное Российское государство объединяет основанный на сохранении и развитии русской культуры и языка, историко-культурного наследия всех народов России единый культурный (цивилизационный) код, который характеризуется особым стремлением к правде и справедливости» [5].

В течение многих столетий письменность является неотъемлемым признаком цивилизации. При современных реалиях человеческого бытия выбор языка - всегда шаг политический, выбор алфавита, графики письма в той или иной степени проблема политическая.

В глобальном информационном пространстве язык, письменности обеспечили и обеспечивают выход человеческого знания за пределы племенной, этнической замкнутости, способствовали и способствуют сближению культур, таким образом, обеспечивая научно-техническое, экономическое, информационное единство разных стран и народов.

Культурно-ценностная система на основе русского языка и кириллического письма, ядром которой выступает российская нация, до сих пор является значимой для всех россиян, всех народов нашего многонационального государства. В этом контексте проблематичен, неоднозначен, вреден по своей сути предлагаемый некими оппозиционными силами в республиках Российской Федерации отказ от кириллицы в пользу латиницы, который нужно рассматривать как «цивилизационное отступление, не говоря о возможном ущербе для российской идентичности» [6]. К тому же надо иметь в виду, что среди множества признаков, факторов этнической идентификации главенствующим компонентом, ядром выступает язык. Мы полагаем, что язык носит 
«системообразующий характер», в социальном пространстве «именно общность языка позволяет обеспечить интенсивное общение» [7].

В условиях интернационализации общественной жизни, усиления глобализационных процессов проблема выбора графики письма перемещается с языковой в политическую плоскость. В таких случаях всегда существуют риски для единой социокультурной и информационной среды. Поэтому сохранение кириллицы как основы письменности народов России - это сохранение исторической памяти и идентичности, единого культурно-языкового пространства жителей бывшего СССР. Наконец, это прочный заслон против разрушения единой социокультурной и информационной среды.

Тем, кто ратует за возвращение письменностей народов Российской Федерации к латинизированной графической основе, хочется напомнить весомые и доказательные высказывания ученых, предостерегающих от такого опрометчивого шага. К примеру, немецкий социальный философ Иоганн Гердер, размышляя о судьбах Рима и его истории, о своеобразии различных исторических эпох и государственных образований, выделяет в качестве определяющих такие факторы, как природные, национальные, социально-политические, культурологические. Он приходит к выводу, что и латинский язык ничего не выиграл от побед над чужими народами, и чужие народы ничего не выиграли от этих побед. В унисон с ним рассуждает французский языковед, сторонник так называемой социологической школы в языкознании Жозеф Вандриес. По его мнению, славянский алфавит - Кирилла и Мефодия - настоящий шедевр. Как далеки от них алфавиты англосаксов и ирландцев. Эти последние приложили много усилий в течение долгих столетий к тому, чтобы приспособить латинский алфавит к своему языку, в полной мере это им не удалось. Известные адыгейские языковеды У.С. Зекох и Ю.А. Тхаркахо, кабардинский ученый М.А. Кумахов и другие считают, что латинский алфавит имеет в своем составе лишь 25 букв, в связи с чем неоправданно быстро оказались исчерпанными возможные графические построения букв для передачи... сравнительно сложной системы звуков адыгейского языка и говорят о нецелесообразности замены ныне действующих алфавитов адыгских языков.

Политизированное стремление к латинице на постсоветском пространстве отчасти объясняется тем, что «приметой прикосновенности к Западу служило и служит 
на европейском Востоке латинское письмо», а кириллица «долгое время фигурировала как графика северных периферийных территорий православных народов, славян и румын». Однако «с политическим крушением Византии и возвышением русского Третьего Рима» разновидности кириллицы постепенно становятся основой алфавитов, тяготевших к «русскому письму». Обозначая признаки цивилизационной отнесенности и цивилизационные идентификации, политолог Вадим Цымбурский довольно точно характеризует письменность как «привходящий цивилизационный маркер». В качестве подтверждения данного тезиса он называет ситуацию с сербской кириллицей и хорватской латиницей в бывшей Югославии, игру с алфавитами в Боснии, переход на латинское письмо Румынии, неоднократные перемены графики в Молдавии [8].

Сегодня свыше ста народов пользуется кириллицей. Латинизированная графика уступила место славяно-русскому алфавиту, но нередко графическая основа того или иного языка становится предметом всякого рода политических спекуляций. Скажем, в северокавказских автономиях, включая и Адыгею, в советский период трижды ликвидировали неграмотность, связанную с изменением графики письма. И теперь «вновь раздаются голоса, что кириллица не отвечает фонетическому составу адыгейского языка». При этом забывается общеизвестный факт: «ни арабское письмо, ни латынь, ни какой-нибудь другой язык в полной мере не отвечает фонетическому составу языков народов Северного Кавказа, в том числе и адыгейского». Тем более, встает еще и проблема транслитерации - передачи букв одной письменности посредством букв другой письменности. При смене графической основы любого письма «огромный духовный пласт научной, художественной, учебной, другой литературы будет практически недоступным, невостребованным» [9].

Важно также учитывать интересы русского, адыгского зарубежья, других многочисленных диаспор, представители которых в своем большинстве ориентируются на принятые в Российской Федерации системы графики письма на кириллической основе.

Бесспорными, если не сказать большего, не могут быть предложения об уместности, желательности возвращения «неславянских языков России к латинице». Есть и более крайние высказывания, в которых переход от арабского письма к латинизированному алфавиту и от латыни - к кириллической (русской) графической 
основе рассматривается, по словам С.А. Арутюнова, как вполне осознанный поворот к «монархической, по существу имперской политике шовинизма и ассимиляторства».

Во всем мире признана нецелесообразность создания совершенно новых алфавитов для бесписьменных языков. При разработке алфавитов младописьменных (новописьменных) языков, кроме лингвистических, чисто языковых доводов, особенностей, во внимание принимались важнейшие факторы научного, общественнополитического, экономического, культурно-исторического, социокультурного и культурно-информационного характера. Учитывалось, что в развитии человеческой цивилизации алфавитное письмо явилось этапным событием, прогрессом в становлении письменной речи, сократило количество знаков до двух-трех десятков, тем самым обеспечивая точную передачу содержания высказывания, расширяя коммуникативные возможности человеческого общения.

Все это отрицается, забывается, когда политика возвышается в ущерб интересам языка, лингвистики. Впервые о возвращении кириллической письменности снова к латинской графике заговорили в Татарстане еще четверть века назад, когда законодатели республики решили отказаться от кириллицы в графике национального письма.

Тоскуя в Лондоне «по малой родине», небезызвестный Ахмед Закаев, оказывается, в европейских условиях возлюбил латинизированное письмо и занялся составлением алфавита чеченского языка, основанного на латинице.

Политики в Хорватии дошли до такого абсурда, утверждая, что хорваты произошли от германских племен и поэтому закономерен их выбор в пользу латиницы, а заговорили они на языке славян, якобы случайно оказавшись в среде южных славян при великом переселении народов. Во всей этой затее просматривается лишь политический подтекст.

Ожидаемым была и реакция наших законодателей. Государственная Дума Федерального Собрания Российской Федерации 15 ноября 2002 года приняла Федеральный закон «О внесении дополнения в статью 3 Закона Российской Федерации «О языках народов Российской Федерации». В результате появился пункт 6 следующего содержания: «В Российской Федерации алфавиты государственного языка Российской Федерации и государственных языков республик строятся на графической основе ЭТНОФИАОСОФИЯ АДЫГОВ: ОТ МИФА К АОГОСУ : 
кириллицы. Иные графические основы алфавитов государственного языка Российской Федерации и государственных языков республик могут устанавливаться федеральными законами» [10].

Из всего изложенного напрашивается вывод: русская письменность, кириллическое письмо на языках народов нашего многонационального государства являются ядром единой российской социокультурной и культурно-информационной среды, разрушение которой негативно скажется на сохранении и развитии общей традиционной культуры в Российской Федерации. Естественно, в мире происходят цивилизационные процессы, а вместе с ними меняются и системы ценностей. Традиционно консервативными остаются алфавиты и графические основы письменностей, которые менее должны быть подвержены политической конъюнктуре.

\section{Литература:}

1. Ключевский В.О. Ф.И. Буслаев как преподаватель и исследователь // Ключевский В.О. Сочинения в девяти томах. - М.: Мысль, 1989. Т. VII. - С. 347-348.

2. Письмена // Мифы народов мира: Энциклопедия. В 2 т. - М.: Советская энциклопедия, 1982. Т. 2. - С. 315-316.

3. Цит. по: Курбатов В.И. Современная западная социология: Аналитический обзор концепций. - Ростов-н/Д.: Феникс, 2001. - С. 255.

4. Ханаху Р.А. Малые культуры в условиях глобальных изменений в мире//Философия. Социология. Культурология. Майкоп.2006. №5. С.153.

5. Стратегия государственной национальной политики Российской Федерации на период до 2025 года. [Электронный ресурc]. URL: http://base.consultant.ru/cons/cgi/online.cgi?req=doc;base=LAW;n=139350 （дата обращения: 10.03.2016).

6. Тишков В.А. Российский народ: история и смысл национального самосознания. - М.: Наука, 2013. - С. 148.

7. Жаде 3.А. Векторы геополитической идентичности. - Майкоп: ООО «Качество», 2007. - C. 145 .

8. Цымбурский В. Народы между цивилизациями // Pro et Contra (Бизнес и внешняя политика). - 1997. - Т. 2. - № 3. - С. 158. 
9. Хуако 3.Ю. От письменности - к книжной культуре: Краткий очерк развития книгоиздания Адыгеи в 1918-2013 гг. - Майкоп: Адыг. респ. кн. изд-во, 2013. C. 14.

10.0 внесении дополнения в статью 3 Закона Российской Федерации «О языках народов Российской Федерации» // Собрание законодательства Российской Федерации. - 2002. - № 32. - С. 3810.

Куек А. С.

\section{Философия единоборства в историко - фольклорной парадигме этноса}

Аннотация: Рассматривается философия единоборства в контексте культурно исторического прочесса. Показано, что адыги издавна, ещуе с нартских времен, уделяли серьезное внимание физическому совершенствованию индивидуума и его духовно нравственному развитию.

Ключевые слова: мифология, нарты, Саусырыко, Пэтэрэз, единоборства, личность, дух воина, деятельность.

Исследование философии единоборств определяется той важной ролью, которую единоборство или единоборства играли, играют и, несомненно, будут еще играть в социальной и культурной жизни общества.

Единоборство исторически связано со многими видами деятельности человека, главными из которых являются: трудовая, воинская, спортивная и др. В то же время единоборства выступают квинтэссенцией, средоточием всего творческого, развивающего и формирующего главные черты и характер личности. На протяжении всей истории единоборства не были простым придатком существовавших типов деятельности, а породили собственный социальный институт, который стал существовать, руководствуясь собственными целями и задачами, логикой своего развития. В основе этой логики - воспроизводство единоборческих отношений и деятельности, воспроизводство личности единоборца. Единоборства формируют мощный стимул для становления идеала целостной и жизнеспособной личности. Этот идеал объединяет в себе представления о таких фундаментальных ценностях, как стремление к самосовершенствованию, самоконтролю, и самозащите [1].

Эти идеалы глубоко фундированы, т.е. заложены, отражены не только в адыгском героическом эпосе «Нартхэр», но и во всей культуре этноса [7]. Весь эпос ЭТНОФИАОСОФИЯ АДЫГОВ: ОТ МИФА К АОГОСУ : 
насыщен высокими идеалами самопожертвования, защиты своих соплеменников, стремлением к подвигу.

Как повествует нартское сказание, ласточка прилетела к нартам и спросила их:

- Я посланница Тхэшхо (Всевышнего). Вам предлагается выбрать одно из двух: жить долго, в празднестве, в достатке, но безвестными, или прожить недолго, но остаться в памяти на столетия как о храбрых, отважных и достойных своей земли витязей.

- Мы выбираем последнее, - ответили нарты, - мы хотим, чтобы наши добрые дела и имена навечно остались в истории, в памяти наших детей [2, с.203].

Так и жили нарты, непобежденными и непокоренными, в вечной борьбе с врагами, но ничем не запятнавшими себя, став примером любви к своему Отечеству. Их жизнь стала идеалом для последующих поколений, о чем свидетельствуют народные предания, давно претендующие на историзм. Адыги себя считают потомками легендарных нартов, непобедимых и храбрых витязей.

Адыги - черкесы, по сведениям европейских и русских исследователей, как правило, отличались прекрасным телосложением, силой и гибкостью. По их мнению, настоящий черкес - это тот, у кого широкие плечи и узкая талия, могучая шея, как у вола, глаза зоркие, как у сокола, и кисти сильные, как волчья пасть. Это был прирожденный воин, а для того, чтобы быть лучше других в противостоянии, надо было быть ловким, смелым и выносливым.

Дореволющионный российский этнограф А. Фонвиль отмечал, что адыги «высокого роста, крепкого телосложения, с правильными лицами и с открытым, смелым взглядом, движения их, легкие и свободные, свидетельствовали о силе и необыкновенной ловкости... чрезвычайно красивы и статны». Адыгский просветитель 19 века Хан-Гирей писал, что «черкесы привыкают к перенесению трудов неимоверных: голод, стужа, жар, усталость, жажда им нипочем...» А Н. Дубровин добавлял, что «равнодушие, с которым они переносили боль, доходило до такой степени, что в этом случае легко было узнать между ними европейца, который мог быть столько бесстрашен, как адыг, но никогда не мог сравниться с ним в терпеливости». Т. Лапинский, много лет живший среди черкесов, отмечал, что «адыг с детства привык владеть оружием. В состоятельных семействах мальчики имеют маленькие ружья, ЭТНОФИАОСОФНЯ АДЫГОВ: ОТ МИФА К АОГОСУ : 
пистолеты, сабли и кам (кинжалы), десятилетние мальчики смело гоняли лошадей, попадают в цель и так привыкают к оружию, что позднее не могут уже жить без него.... Даже старики 80 лет и более...». Целью воспитания и обучения были «выработка качеств, как любовь к Родине, к свободе, воинственность, храбрость, скромность, уважение к женщине, к детям, к старшим и беспрекословное выполнение распоряжений последних».

Особое внимание обращалось на высокую степень владения оружием, секретами верховой езды. В адыгском обществе можно было прославиться только отвагой, мужеством и храбростью, в сочетании с ясным умом. При выборе жениха девушка в первую очередь ставила именно эти качества, а не юный возраст и красоту.

Для верховой езды в основном использовались черкесские породы лошадей, которые по праву считались одними из лучших в мире, они славились своей выносливостью, непритязательностью к еде и преданностью хозяину. Вместе они тренировались и настолько сближались и понимали друг друга, что, образно говоря, становились наподобие кентавра. Символические образы необыкновенных лошадей воплощались в эпические альпы, которые не только могли летать, но и обладали разумом и владели человеческой речью, Таким был чудесный конь нарта Саусэрука Тхожий, Чэмыдеж у Шэуая, Дуль-дуль Пэтэрэза, Пчегуалэ Ащэмэза. А Джэманшэрик легендарного героя Айдэмыркана обладал прекрасными качествами боевого коня. В песне об Айдэмиркане поется, что:

«Всадники, когда ринутся, земли не касаясь (приходит первым),

Его глаза, что заметят, то от Джэманшэрика не уходит...»

В случае военной опасности, когда народ брался за оружие, черкесский воин становился настоящей грозой для врагов. «Только одно могу похвалить, - писал о черкесах астраханский губернатор Петру 1 в 1721 году, - что все такие воины, каких в здешних странах не обретается, ибо, где татар или кумыков тысяча, тут черкесов довольно двухсот. И никто против них не стоит, и все от них трепещут...» [3, с. 241]. Для того чтобы стать таким воином, недостаточно одного мужества, естественно, необходима еще соответствующая физическая подготовка. Этому уделялось особое внимание, и примером служили легендарные нарты. 
Любовь нартов к единоборству, стремление стать сильнее, лучше, выше других нашло яркое отражение в сказаниях. Ежегодно нарты собирались на собрание Хасэ, где устраивали богатырские игры со Стальным Колесом (Чанщэрэхъ), которое спускали с вершины Харам горы (Хьэрам 1уашъхь). Один из нартов встречал его у подножия и ударом лба, ноги или ладони загонял обратно на гору. В этом особо отличался нарт Саусэрук.

Нарты любили бороться, особенно в хэч-хасэ (Хэч-хас. букв.: вырви-забей), цель которой состояла в том, чтобы вогнать противника в землю как можно глубже. Такие игры помогали набирать мастерство, ловкость, что потом, в реальных противостояниях нартов с врагами, им помогало одолеть противников. Нарты славились своей ловкостью. Нарт Шэбатынук (Шэбатыныкъу), например, всаживал меч в землю острием вверх и плясал на его кончике.

Военная игра «шыурытлес» (шыурэ лъэсырэ - всадник и пеший) была особо популярна среди нартов.

«Нарты нас позвали,

Нарты нас пригласили и...

- Шыурытлес поиграйте! - сказали.

Нартов под стрехи я загнал,

В круг я ворвался и...

Шыблэ (Громовержец) волом молодым заревел,

Свою богатырскую пику сломал и...

Богатырский рог мне вручили», - так повествует нартское предание.

Конечно, это был Саусэрук, его, молодого нарта, подвергали испытаниям. Ведь на нартские игры всегда приглашали самых сильных витязей, здесь каждый мог себя проявить по достоинству.

«Собрали хасу, сильные мчались туда,

И малого мужа, молодого Сосруко,

Нарты пригласили на хасу.

Сел Сосруко на коня и прибыл на хасу.

Когда Сосруко въезжал во двор, его попросили:

« Поиграй на шаратлес!» 


\section{Сосруко на своем Тхожее}

Поиграл стократно,

Ударяя, словно молния (длиною) в семь змей.

Кого ударит - тот отлетает.

Скрежещет на них зубами,

Уздечку держа, -

На седле, словно троне, -

«Хыу» сказавши, поворачивается,

Приводит в трепет тех, на кого

Он задумывает напасть,

Прыгает, словно кошка.

Тут засуетились нарты вокруг него, приказали: «Поднесите ему рог мужества!» Принесли рог мужества, и он осушил его. Выполнив все, что положено по обычаю, Сосруко уехал (с хасы) [4, с.196].

Эта игра проходила так. Группа молодых людей окружает обрядовые пляски, защищая их от всадника, который стремится прорвать кольцо пеших, ворваться в плясовый круг, схватить девушку и вынести ее за ворота. Чтобы отогнать всадника, его бьют палками, стараются сбросить с коня; всадник, чтобы прорваться к плясовому кругу, старается рассеять противников. Исход борьбы был непредсказуем, если побеждал всадник, то тхэмадэ (распорядитель праздника) ему вручал богатырский рог, наполненный белым вином (батырыбжъ) или крепко выдержанной брагой из проса и меда (мэрэмжъый).

Противостояние всадников и пеших проходило и в другом виде. Когда невесту привозили, пешие пытались не пропустить ее во двор, а всадники, сопровождавшие свадебный фаэтон (кухъэрин), стремились оттеснить пеших, вооруженных длинными палками. Последние били и коней, и всадников, противостояние иногда доходило до увечий, но никто не сдавался, считалось, что это тоже показатель храбрости.

Надо сказать, что несгибаемый дух народа, воля к жизни, готовность пожертвовать жизнью для своей Отчизны делали адыгов рыцарями Кавказа, система их жизни становилась примером для других народов. При всей сложности жизни философия адыгов подразумевала, что человек должен быть всегда выше любых 
житейских проблем. Адыги считают, что бог накладывает на человека столько испытаний, сколько он сможет выдержать, поэтому сила духа становилась выше всего. Народ мог жить полнокровной жизнью в своих прекрасных празднествах или достойно, с мужеством переносить все тяготы жизни. Это называлось «шэтапкъэ» - испытание, испытание и радостью, и горем.

Почему черкесы были так сильны в единоборствах, почему каждый из них представлял себе «целое» государство, независимое ни от кого? Коллективное им не было чуждо, но они предпочитали все решать самим, своими силами, надеялись только на себя. Это было заложено в их философии духа, в их стремлении быть только первыми и никого не бояться. В мифологии адыгов есть место даже для противления Богу. «Нет в мире ничего, чего бы я боялся, - говорил известный поэт, драматург и писатель, признанный философ Нальбий Куек. - Обычно мы говорим, что кроме Всевышнего никого не боимся, но мы и его не боимся, мы его любим и уважаем. Зачем бояться Того, кого ты любишь и когда ты знаешь, что и Он тебя...»

Отменная физическая сила, несгибаемый дух помогали настоящим мужчинам выжить и пройти достойно все испытания. Это подтвердил в свое время и Чилар Хашир, адыг из селения Кучмазокино (совр. Баксан) в Кабарде, который совершил величайший альпинистский подвиг на Кавказе 10 июня 1829 года. Он в 11 часов утра без предварительной подготовки с первой попытки первым в мире покорил Эльбрус (1ошъхьэмаф).

Восхождение было организовано командующим Кавказской линией генералом Г. А. Эмануэлем, который привлек к экспедиции геофизика, геолога, физика, зоолога, ботаника и художника, а также интернациональную группу из кабардинцев, балкарцев и казаков. Большинство не смогло преодолеть высоту 4270 метров из-за горной болезни, a Хашир, казак Лысенков и физик Ленц добрались до высоты 5350. Килар Хашир продолжил восхождение в одиночку, когда его спутники, обессиленные и изнуренные, повернули обратно. Генерал Эмануэль, наблюдавший за происходившим в подзорную трубу, увидел, как храбрый черкес взошел на самую макушку восточной вершины.

Российская Академия наук в 1829 году заказала мемориальную плиту, которая увековечила подвиг Хашира. Впоследствии многие альпинисты поднимались на самую высокую гору Европы, но первый есть первый. Здесь нужно отметить: восхождение на 
Эльбрус для Хашира являлось не только победой его физической мощи, но и преодолением страха перед самой горой. В адыгской мифологии и нартском эпосе считается, что на Ошхамафе жили их боги и гора имела своего покровителя. Простому человеку воспрещалось подниматься на священную гору без позволения небожителей. Это в эпоху нартов боги сами выбирали и приглашали к себе на санопитие богов лучшего нарта один раз в год. И то, что адыгские боги позволили первым подняться на место своего обиталища потомку легендарных нартов, говорит о том, что и он был избран богами. А то, что он имел богатырскую силу, выносливость, целеустремленность, отвагу - это следствие особого воспитания мужчин - мужчин, достойных своего Отечества.

Тебу де Мариньи считал, что «воспитание черкесов состоит из всякого рода упражнений для тела, чтобы сделать его сильным и ловким; из обучения верховой езде, борьбе, стрельбе из лука, ружья, пистолета и т.д., ребенка обучают искусству руководить набегом, ловкости, умению переносить голод и усталость, стараются развивать в них красноречие и способность к рассуждению, с тем, чтобы они могли влиять на собрание».

Особое внимание уделялось нравственному воспитанию, в присутствии детей взрослые не говорили ничего, что могло плохо повлиять на них. Надо отметить, что система воспитания адыгов, отшлифованная веками, рассматривалась не как узкое семейное дело, весь род, село принимали участие в воспитании детей. В этом плане наиболее эффективным становилось общественное мнение. Никогда старший не проходил, чтобы не сделать замечание ребенку, совершающему какой-либо недостойный поступок, он мог его наказать и потребовать от него, чтобы он непременно сообщил отцу о случившемся. Хотя наказания могли быть и телесными, но убеждение считалось наиболее эффективным, считалось, что если родители бьют детей, значит, они не могут их по-другому воспитывать. И дети, воспитанные не страхом, а убеждениями, становились свободными в мыслях своих, не стесненными раболепием.

Особо нужно подчеркнуть взаимоотношения отца и сына. Адыги умело избегали в воспитании чувства «комфортности», обычно отец строго воспитывал сына, был всегда к нему требовательным, никогда не показывал при посторонних свою привязанность и любовь к нему. Считалось постыдным брать и ласкать его на виду у 
кого-то, жалеть и оберегать его от тяжелой работы, плакать в случае его смерти. По этому поводу существует одно любопытное предание. «Один мужчина возле пропасти вел оживленный разговор с собеседником, - повествуется в нем. - Здесь же, недалеко, играл его сын, бросая камешки в пропасть. Внезапно он подошел очень близко к краю обрыва, и при попытке очередной раз кинуть камень он начал падать в пропасть. Отец, продолжая разговор, неторопливо, как бы невзначай, наступил на рубашку сына и удерживал его, пока подбежавший мальчик не забрал его».

Не только отцы, но и матери строго воспитывали сыновей и в обществе не показывали свою материнскую любовь к ним. Однажды после кровопролитного сражения к пожилой женщине привезли погибших в войне шесть ее сыновей и мужа. «Достойно ли они сражались, умерли храбрецами или трусами?»- спросила мать. Получив ответ, что они отличились в бою, она только вздохнула, не проронив ни одной слезы. Это пример сурового отношения адыгов к тем, кто проявил трусость в бою.

«У Санджалия большая битва,

Мужчина, не участвующий в ней, трус.

Два труса выглядывают из-за кургана,

Присматриваемся к ним - похожи на девушек.

Назвали бы их девушками,

Но с шашками на боку и сидят на конях,

Назвали бы их невестами,

Но в мужскую одежду облачены они -

Порыжевшие две черкески одноцветны,

Вы подобно тем, кто с вами сидит

Карамузыко Ракат и Ерымыко Нагой...»

Имена трусов названы, они будут презренны, даже их жены им говорят:

«То, что не смогли разрядить (ружья)

У Санджалия,

Не кладите перед нами...»

А М. Ю. Лермонтов в стихотворении «Беглец» так описывает встречу матери и сына труса:

«Ты умереть не смог со славой 
Так удались, живи один.

Твоим стыдом, беглец свободы,

Не омрачу я старые годы,

Ты раб и трус и мне не сын» [4].

Трусы, покинувшие поле битвы или спрятавшиеся от войны, были презираемы в народе, на головы их матерей и женщин одевали специальный пестрый головной убор - п1ынэ, чтобы все видели, какой в их семье мужчина. Если в очередном бою он отличался храбростью, с женщин снимали позорный головной убор, и доброе имя возвращалось к мужчине. Поэтому мало кто осмеливался не выходить на поле брани, а храбрецы удостаивались славы.

«Он был в бою непобедим

Пшимаф Батоков!

В ночное время оберегал стан, как днем,

Оберегает людей крепость!

У него было лицо железного цвета, и сам он был

Железный человек, свист пуль его тешил,

Берзек Едиков!» - так восхваляли героев.

О храбрости черкесов писал и великий русский поэт А.С. Пушкин:

«Но европейца все вниманье

Народ сей чудный привлекал.

Меж горцев пленник наблюдал

Их веру, нравы, воспитанье,

Любил их жизни простоту,

Гостеприимство, жажду брани,

Движений вольных быстроту

И легкость ног и силу длани;

Смотрел по целым он часам,

Как иногда черкес проворный,

Широкой степью, по горам...

Летал по воле скакуна,

К войне заране приучаясь. 


\section{Он любовался красотой}

Одежды бранной и простой.

Черкес оружием обвешан;

Он им гордится, им утешен;

На нем броня, пищаль, колчан,

Кубанский лук, кинжал, аркан

И шашка, вечная подруга

Его трудов, его досуга.

Ничто его не тяготит,

Ничто не брякнет; пеший, конный -

Все тот же он; все тот же вид

Непобедимый, непреклонный» [5, с. 99-100].

Несомненно, в черкесском мире, да и у других близкородственных нам народов, как абхазы, абазины, грузины и т.д., особое внимание уделяли индивидуальному воспитанию представителей элиты, которым предстояло вести за собой целые этнические группы. Так происходило и на Кавказе и даже после депортации кавказских народов в Османскую империю после Русско-Кавказской войны. Мудрые представители абхазского и черкесского народов умело сочетали физическое и духовное воспитание подрастающего поколения. Здесь уместен поучительный пример абхазского аристократа Мурата Ягана, проживавшего в Турции, и мы приведем выдержки из его воспоминаний.

«Когда за меня взялись старейшины, я не услышал от них ничего такого, что противоречило бы вещам, усвоенным мною раньше, - вспоминает автор книги «Я пришел из-за гор Кавказа» М. Яган. - Собственно говоря, они учили меня вовсе не религии, а тому, что стоит над религией. Вместо ортодоксального учения ислама, которое опирается на идеи воздаяния, кары и наших обязательств перед Творцом, мне говорили о Любви. Причиной всего сущего, как гласит абхазская мудрость, стал некий любовный союз, заключенный в Космосе. Мы - плоды этого любовного союза. Как существа, наделенные сознанием, мы причастны к источнику этой творческой силы.

Я слушал старейшин, но тогда их слова меня не интересовали. Отец прекрасно разбирался во всех мирских делах. Он общался и с черкесами, поэтому, когда меня 
избрали его преемником, вожди всех племен, а не только нашего, собрались, чтобы выработать совместный план моего обучения. В течение двадцати шести месяцев меня обучали разные старейшины по очереди, но один из них находился при мне практически постоянно. В соответствии со своим происхождением он выполнял обязанности не только моего наставника, но и слуги. Звали его Алхас.

Это был очень старый человек - ему давно перевалило за сотню. Маленький и жилистый, с виду он походил на обезьяну, но был необычайно крепок и ловок. В его обществе, с небольшими перерывами, я провел целых два года. Он прибыл в Турцию еще с моим дедом Сатом и остался с ним, когда основная часть племени по распоряжению султана была отделена от прадеда и поселилась в Мараше. Он всегда появлялся на школьном дворе неожиданно - безупречно одетый, с аккуратно подстриженной бородкой - и сразу обращал на себя общее внимание. Правда, мои однокашники не слишком удивлялись его необычному облику, хотя большинство из них принадлежало к османскому роду. При дворе Османов издавна жили кавказцы.

Алхас подолгу сидел около дверей, но было видно, что он в любой момент готов вскочить и приняться за дело. Он никогда не выглядел вялым. Иногда приходили троечетверо пожилых черкесов - и забирали меня, одетого как они сами, на долгую прогулку в горы. Мы бродили там по семь дней и ночей - они шли, смеялись, подшучивали друг над другом, а я учился прислуживать им, мыл ноги каждому по очереди и делал все, что требовалось. Мне давали разные задания - например, забраться в труднодоступное место, чтобы достать оттуда что-нибудь, или принести моим спутникам воды, не пользуясь сосудом. Из меня воспитывали настоящего воина.

Чтобы укрепить мышцы рук, я должен был ежедневно упражняться с глиной. Ком глины величиной с хороший тюк клали на скамью, пень или стол, сколоченный из толстых досок. Глина была мягкой и очень скользкой. Я закатывал рукава выше локтей и, распрямив пальцы и сжав их вместе, погружал в глину сначала одну руку до самого запястья, затем другую - туда и обратно, в течение двадцати - десяти минут. Через полчаса надо было снова подойти к скамье и отработать еще десять минут, потом еще десять, и так далее.

На ночь сырую глину заворачивали в мокрую тряпку, чтобы она не высохла и не затвердела. Я упражнялся с одной и той же глиной по нескольку дней, и лишь потом ЭТНОФИАОСОФИЯ АДЫГОВ: ОТ МИФА К АОГОСУ : 
она становилась для этого непригодной. Под конец я мог втыкать руки в глину и выдергивать их из нее по два часа кряду, и мои пальцы стали крепкими, как наконечники копий. Человек, натренированный таким образом, способен с легкостью пробить рукой стену или стол, а если понадобится, выпустить из врага кишки, то и четыре слоя брюшных мышц.

Когда упражняешься с глиной изо дня в день, ногти на руках постепенно слезают до тех пор, пока от них ничего не останется. Потом нарастают новые - толстые, крепкие и безобразные с виду. Месяца через три-четыре эти ногти становятся совсем другими, очень блестящими и красивыми, будто выточенными из мрамора. Человека, долго тренировавшегося с глиной, можно отличить по его рукам. К сожалению, чем эти руки красивее, тем они опаснее, точно змея. Такими руками можно раскроить череп и пробить насквозь грудную клетку...»

Здесь уместно сказать, что при описании облика черкеса-воина, кроме атрибутов оружия и доспехов, особо подчеркивалась его физическая сила, «широкие плечи и узкая талия, шея могучая, как у вола, глаза зоркие, как у сокола, и кисти сильные, как волчья пасть». Автору данного материала удалось найти формы и методы физического совершенствования юношей, чтобы они могли стать такими, однако подтверждения обладания необычными «кистями, как пасть волка», не было. Рассказ Мурата Ягана о его воспитании кавказскими старейшинами позволили дополнить недостающий элемент физического воспитания горца...

«В перерывах между упражнениями с глиной я должен был выполнять и другие задания, - повествует дальше М. Яган. - Меня заставляли бегать, висеть на перекладине как можно дольше - сначала на обеих руках, потом на каждой поочередно, потом на ступнях и на коленях. После всего этого надо было идти в парильню, а затем нырять в ледяной бассейн.

Меня учили обращению с саблей, причем сначала вместо нее мне дали почти двухметровый шест: я работал с ним двумя руками, а затем одной, как левой, так и правой. Я научился защищаться. Я ездил верхом с шести лет и чувствовал себя абсолютно свободно на любой лошади, и теперь меня научили на всем скаку аккуратно разрубать саблей подвешенное на веревочке яблоко. Без этой забавы у абхазцев не обходится почти ни одна свадьба. Победителем состязания считается тот, кто сумеет 
разрубить яблоко как можно ближе к середине, чтобы получились две почти одинаковые половинки.

Обучали меня и другим акробатическим трюкам и играм. Одна из них называлась «джирит». Ее участникам выдают легкие копья длиной чуть меньше полутора метров, и они мечут их друг в друга, скача на лошадях во весь опор. Сделанные из специального камыша, копья летят очень ровно. На конце у каждого копья есть тряпочка, смоченная чернилами из сока некоего ползучего растения, поэтому на каждом игроке, в которого попадает чужое копье, остается отметина. По правилам, участник выбывает из игры после того, как его трижды «ранят» в руку или ногу либо один раз в грудь или голову.

Акробатические упражнения, которые я должен был выполнять, скача верхом, тоже предназначались для того, чтобы сделать из меня умелого воина. При нашем стиле ведения боя человек должен уметь ловко вскакивать в седло, стрелять из-под шеи своего коня, прятаться от противника, повисая то на одном боку коня, то на другом, - и все это в считаные секунды. После упорных тренировок лошадь стала как бы дополнительной частью моего тела, абсолютно мне послушной, и так же чутко реагировала на все мои движения, как я - на нее.

На всех тренировках обязательно присутствовали старейшины - они давали мне задания, объясняли, что и как надо делать, и заставляли меня повторять каждое упражнение до полного изнеможения. Когда я уставал, они безжалостно требовали продолжать тренировку, и тогда происходила странная вещь: после того как я выматывался настолько, что едва не падал с ног и начинал хватать ртом воздух, в моем организме что-то переключалось, и я вдруг ощущал новый прилив сил. Кризис оставался позади, и у меня возникало чувство, будто я могу продолжать свои действия до бесконечности. Вся слабость куда-то испарялась, и мне начинало казаться, что упражнения, которые я делаю, выполняет вместо меня кто-то другой. В такие моменты я иногда словно отделялся от своего тела и впадал в экстатическое состояние, подобное трансу. Но как только старейшины замечали во мне эту перемену, они немедленно прекращали тренировку.

В часы занятий старейшины, которые проявляли по отношению ко мне такую строгость, называли меня «господин Мурат» и не садились в моем присутствии, пока я 
им этого не предлагал. В другое время они скромно сидели у дверей, пристально следя за тем, не понадобится ли мне что-нибудь, всегда готовые отворить дверь, принести нужную вещь, оказать мне любую услугу; но когда дело доходило до тренировок, они начинали мною командовать. Я был воспитан так, что беспрекословно их слушался; однако я не мог избавиться от чувства, что все это глупо, поскольку мне никогда не придется делать то, чему меня учат.

Когда мои наставники говорили, что человек не умирает, это казалось мне бессмыслицей. Когда они объясняли, что у человека множество тел и хоронят только одно из них, а прочие продолжают существовать, я смеялся про себя. Мне говорили, что похороны - это лишь способ почтить тело, которое выполнило свою работу, что таким образом мы отдаем дань уважения этому телу и сообщаем об этом другим телам. Я думал, что мои соплеменники темны и невежественны, и считал те сведения, которые мы получали в Галатасарайском лицее, гораздо более важными.

Мне казалось, что я умнее своих наставников, и я относился к ним с тем легким презрением, на какое способен только ребенок. Они же были спокойны и терпеливы, и лишь потом, когда я стал бекташи, или турецким дервишем, мой шейх объяснил мне всю важность и ценность того обучения, которое я прошел под их началом. Организовать это обучение было несложно, потому что, перебравшись в Стамбул и его окрестности, кавказские аристократы почти не изменили своего образа жизни. Они поселились в больших усадьбах площадью в десять-пятнадцать акров каждая и выстроили себе дома в стиле кавказских замков. Некоторые из этих величественных домов стояли прямо на берегу Босфора и их фасады были обращены к проливу...

Большинство моих наставников были по национальности убыхами (мать моего отца тоже принадлежала к этому племени). Убыхи и абхазцы очень близки по происхождению, но говорят на разных языках. Почти девяносто процентов убыхов погибли при переселении с Кавказа в Турцию. Они сели на корабли, намереваясь переплыть Черное море, но поскольку морская стихия была незнакома этим жителям гор, первый же шторм оказался для них роковым, и все побережье от Анапы до Сочи усеяли их мертвые тела. Уцелели очень немногие. Сейчас в Турции есть пять-шесть селений, где живут иммигранты-убыхи: эти селения в основном находятся между Стамбулом и Анкарой, а некоторые - близ Бандырмы. 
Два с половиной месяца я провел в кабардинском поселке в Анатолии. Тамошние жители с давних времен отличаются благородством манер и в совершенстве владеют искусством верховой езды; в конце семнадцатого века они были учителями казаков, поселенных в районе Дона и Днепра русским царем Петром Великим. Кабардинцы обучали их ездить верхом и биться на саблях. Я тоже прошел у них курс обучения верховой езде и сабельному бою.

Кавказская сабля очень необычна - она гибкая и тонкая, точно хлыст, и может использоваться только при нападении. Защищаться ею нельзя, так как она не выдерживает сопротивления воздуха, но даже маленький мальчик, научившийся правильно ею владеть, может перерубить пополам корову. Правильное владение такой саблей требует большой точности. Мой отец - а он был левшой - мог аккуратно сбрить ею верхушки поставленных в ряд яблок и даже воспроизвести несложную мелодию, рассекая саблей воздух...»

Далее Мурат Яган говорит об особых упражнениях, позволяющих в полной мере развить способности тела, а также контролировать и активизировать внутренние точки, которые назывались «космическими гнездами». Очень большое внимание уделялось умению правильно дышать, искусству снабжать кислородом различные органы, выбирая их по своему желанию. В течение двух лет его развивали физически и умственно, передавая ему знания. «Я не знал, что старейшины - абхазцы, мои бывшие наставники, прекрасно владеют искусством астральных путешествий, - вспоминал он. Все связанное с древними традициями казалось мне устаревшим, архаическим. Я имел преимущество перед своими сверстниками, потому что те навыки, которые привили мне старейшины - абхазцы, сделали меня практически непобедимым. Я великолепно стрелял и мог, почти не целясь, попасть из обычного пистолета в черенок листа, растущего на дереве, а потом и в сам лист, падающий на землю...» [6, с.18-32].

Говоря о системе воспитания у адыгов, следует отметить и особое отношение к эстетическому воспитанию, которое носило целенаправленный характер. У них формировался эстетический вкус, они приобщались к прекрасному. Считалось, что «на всем, что делал и подготовлял адыг, лежала печать вкуса».

«Черкесы в сравнении со всеми прочими кавказскими племенами были тем, что в Европе привыкли считать французов, - писали о них. - Законодатели всякого рода ЭТНОФИАОСОФИЯ АДЫГОВ: ОТ МИФА К АОГОСУ : 
моды: в костюме (черкеска же подошла всему Кавказу, она даже стала национальной одеждой казаков, а царь в праздничные дни любил ее носить), в оружии, в седловке, в манере верховой езды, в законах и обычаях - от самых важных до мелочных, до горского этикета и т.п.»

Основным средством воспитания, умственного и физического развития считались, естественно, народные игры, а их у адыгов было немало. Изучение народных игр для познания всей философии воспитания молодежи имеет большое значение. Для воина очень важны тренировки, шлифовка техники владения оружием, для молодых и сильных мужчин иногда полем «битв» становились и спортивные игры, состязания на празднествах.

В круг популярных видов черкесских игр входили поднятие подростка (к1элэкъэ1эт) или поднятие камня (мыжъокъэ1эт), метание камня (мыжъодзын), метание копья (пчыпыджын дзын). Последние виды упражнений имели военное значение, например, метание камней было связано с военными действиями в горах. Кто желал бросить камень, выходил в круг, клал тяжелый камень на правую ладонь, поднимал на уровень плеча и со всего размаха кидал через себя назад. А небольшие камни кидали на расстояние, например, через реку. Кто толкал или кидал дальше других, побеждал. А совсем маленькие камни метали в цель.

Копья у адыгов были легкими, красивыми и блестящими. Они были деревянным снарядом в форме рогатины с металлическим наконечником. Соревнования проводились в цель и на дальность расстояния. Шора Ногмов упоминал, что «адыги ловко метали копья». В нартском эпосе упоминается особое копье пчы т1аркъу, принадлежавшее нарту Тотрэшу, а также дротик (1эш1ок1). Имеются упоминания о бытовании у адыгов боевого топорика маитэ.

Особое внимание уделялось фехтованию. Известно, что у адыгов для этого были два вида оружия: сабля колчанная (чатэ) и шашка (сэшхо). Кстати, в русском языке появилось слово шашка от сэшхо. Чатэ предназначалось для того, чтобы рубить и колоть, а сэшхо, чтобы только рубить. Дети проходили обучение сначала на деревянном оружии. Уроки фехтования проходили практически ежедневно. Само фехтование являлось составной частью военно-спортивных игр, это было довольно опасным 
занятием, но по этому поводу адыги сказали: «Кому не страшно в день игры, тот не устрашится в день битвы».

Юноши и подростки увлекались прыжками в высоту или с места, кто дальше. Ходьба тоже имела большое значение в физическом развитии молодежи. А. Павловский писал, что адыги «развивают свои мускулы и гибкость в членах и суставах своими ежедневными физическими упражнениями - всходят на горы, спускаются с гор, прыгают через деревья, рвы, канавы, переходят через ущелья и горные ручьи по тонкому качающемуся бревну, карабкаются по крутым склонам гор, сбегают вниз».

А навыки быстрого бега помогали при охоте на животных и ловле лошадей. В адыгских преданиях есть упоминания о том, что ловкие юноши догоняли оленей и ловили их за задние конечности. Бег обычно проходил и по ровному месту и по территории с естественными препятствиями, которые приходилось преодолевать прыжками и лазанием. А лазание способствовало развитию силы, ловкости и выносливости. Те, кто проживали на берегу крупных рек и моря, увлекались плаванием, греблей. Также были игры в бабки, верчение волчка, постегиваемого кнутом (чынэ), катание с заснеженных горок и другие.

Следует отметить, что у адыгов были не только народные физические игры, но и интеллектуальные состязания. Еще нарт Саусэрук придумал игру, похожую на шахматы и шашки - сэнт1ращ, но правила игры не сохранились. Адыги увлекались национальными адыгскими шашками - «пхъэк1эн». Данная игра имела различное число комбинаций, что давало большие возможности для интеллектуального развития играющих.

Об одной еще интеллектуальной игре, основным назначением которой являлось развитие красноречия и логического мышления, чаще всего практиковавшейся в элитной среде - у князей и дворян - следует указать. Как описывает Хан-Гирей, суть игры заключалась в том, что участники игры «делились на две партии, и одна из них предъявляет свои претензии другой под каким-нибудь предлогом. Тут избирают судей, перед которыми ответчики защищаются силой красноречия, претендующие не щадят могучих выражений для побеждения своих противников. Таким образом, открывается здесь поле, где старшины, князья и дворяне показывают могущество своего красноречия и знание существующих узаконений народных и феодальных прав древних 
фамилий, своей нации. Забава эта, или лучше, упражнение в словесности, служит у черкесов школою, образующей непреклонных их ораторов».

Но особо любимыми были все-таки народные физические игры, а из них скачки, состязание за обладание шкурой барана, джигитовка, конные пляски, стрельба по мишеням и, конечно, борьба становились волнующим зрелищем. Изделия самых искусных девушек: шелковые плетеные шнуры и сафьяновые чехлы для пистолетов, вышитые золотом кисеты, башлыки, носовые платки и другие изделия - становились призами.

Состязания по стрельбе из лука в цель всегда были зрелищными и азартными. Особой похвалы удостаивался тот, кто побеждал в этом интересном единоборстве. Однажды нарты сошлись у гребня горы, куда поставили семь яиц, они были едва видны. Но искусный стрелок Пэтэрэз «велел положить их еще дальше. Он сбил все семь яиц стрелами, а стрелы другого нарта даже не долетели до мишени». А в другом месте состязались нарты Пэнуко и Саусэрук:

«Выступает Пэнуко,

Он достает стрелу из колчана,

Достает и пускает

Прямо в небо из лука.

Нарты режут барана,

Нарты шкуру снимают;

В этот миг из-за тучи

Вдруг стрела прилетает

И вонзается в землю

У разделанной туши.

Души нартов ликуют,

Все пришли в восхищение

От умения Пануко.

... И стрельбу свою в небо

Он (Саусэрыко) пускает из лука.

Тут быка режут нарты,

Тут быка варят нарты, 
А стрелы все не видно.

Вдруг стрела показалась,

В круглый столик вонзилась,

Середину пробила!

Огласило долину

Нартов громкое слово:

«Слава, слава, Саусэрук!

Нартам чудо явил ты,

Удивил ты всех нартов

Удалою стрелою».

Верховая езда занимала особое место в народной системе физического воспитания адыгов, и поэтому они имели большое количество конно-спортивных игр, которые сопровождали народные гуляния, значительные семейные праздники. Эти игры имели прямое отношение к военной выучке, боевому искусству, которые достигались неустанными тренировками.

Во многих фольклорных материалах, где эпизоды единоборства показаны очень ярко, красочно, часто встречаются противостояния всадников, обязательно продолжающих борьбу на земле. Когда мечи и кинжалы отбрасываются в сторону и два соперника переходят к борьбе, обычно выигрывал тот, кто был искуснее.

«Два коня сошлись и сшиблись, - повествует нартское предание, -

Разом два луча блеснули,

С лязгом два меча сверкнули -

Гул раздался, и в долинах

Отозвался поединок.

То, взлетая в поднебесье,

Бурей на конях крылатых,

Гром тогда гремел в лазури

От ударов их булатных;

То спускались вновь на землю,

Расходились и сходились,

В доблести друг другу, в силе, 
В ловкости не уступая.

Снова в яростном разгоне

Сшиблись кони, огрызаясь;

Кони вздыбились и разом

Наземь сбросились отважные».

А в другом нартском повествовании описывается, как боролись нарты Пшая и Саусэрук:

«Пшая нарт низколобый

Черной злобой пылает.

Он хватает Саусэрыко,

Поднимает и вертит! (бросок, известный в борьбе как «мельница»)

Меж ног стальными

Он свою ногу ставит (переворот с подсадом ногой),

Он противника давит,

Чтоб сломить его силу (элемент черкесской национальной борьбы «бгыгъэуз» сдавить пояс, чтобы стало больно)».

Борьба была любимым видом единоборства, и среди адыгов были искусные борцы. Черкесская борьба включала в себя приемы нападения и самозащиты, смысл которых сводился к тому, чтобы заставить соперника коснуться земли какой-нибудь точкой тела, кроме подошвы ног. В истории есть немало подтверждений, что адыгская система борьбы была совершенной. Об этом, кстати, свидетельствуют русские литературные источники. Например, в «Древнероссийских стихотворениях» под редакцией Данилова описывается противостояние брата Марии, жены Ивана Грозного Мастрюка Темрюковича, с русским богатырями.

«Изошел он (Мастрюк Темрюкович) семь городов,

Поборол он семьдесят борцов.

И по себе борца нашел -

И только думает: ему вера

поборотная есть

У царя в каменно Москве...

С борцами сходится Мастрюк Темрюкович: 
борьба его ученая, борьба черкесская,

колесом он бороться пошел...».

Адыгская борьба имела две модификации: борьба поясничная (бгырыбан) и запястная борьба (1эпшъэрыбан). Задача состояла в том, чтобы силой или с помощью приемов свалить противника на спину, навзничь. Если борцы падали на землю одновременно боком или лицом вниз, объявлялась ничья, и борьба продолжалась, пока один не победит.

Специалисты, изучающие дзюдо, сходятся во мнении, что «дзюдо является не просто видом спорта, а философией воспитания путем социально осмысленного движения в прикладных целях, частью японского духа, жизни, основой для воспитания молодежи». В этом плане адыгская система воспитания путем физических упражнений и массовых игр тоже являлась составляющей философии народного воспитания, созвучна японской.

Используя систему дзюдо, лучший тренер XX века, основатель всемирно известной майкопской школы борьбы Якуб Коблев отчасти восстановил адыгскую систему привлечения молодежи к спортивным играм, обеспечил преемственность в своей школе, своеобразном Кодокане, созвучном Храму дзюдо Кодокану в Японии. В основе обеих школ - воспитание физически сильного, духовно - нравственного индивида, выделявшегося в обществе своим воспитанием и благородством.

Таким образом, адыгская система единоборства породила собственную философию, ориентированную на особенности социально-культурных традиций этноса, со смыслами, установками этнической педагогики, способную эффективно формировать и развивать физически и духовно - нравственную личность.

\section{Литература:}

1. Передельский А.А. Единоборства и их спортивная традиция. URL.http://www.sportwik.to. C.6-7.

2. Нартхэр /Нарты/. Адыгэ эпос. Зэфэзыхьысыжьыхи зэхэзгъэуцуагьэхэр, ублэп1э очеркымрэ комментариехэмрэ зытхыгъэр Хьэдэгъэл1э Аскэр. Мыекъуапэ, Краснодар крайисполкомым хэутынымк1э и Гъэ1орыш1ап1э и Адыгэ хэку типографие. т.т.1-УП. - н. 2424; том 1, 1968. - н. 320; том 2, 1969. - н. 354; том 3, 
1970, - н. 354; том 4, 1970, - н. 309; том 5, 1970. - н. 336; том 6, 1971. - н. 322; том 7, 1971. - н. 428. Далее: номер сноски, том, страница.

3. Цит. По Гергов Х.Х. «Адыги (черкесы) чемпионы Европы, мира, Олимпийских игр». - Нальчик, 1998, С. - 272.

4. Нарты. Адыгский героический эпос. М.: Изд-тво Наука, 1974, С. 404.

5. Лермонтов А.М. Беглец. www. Libraru.ru/texst/1329/p.index.htmt

6. Пушкин A.C. Кавказский пленник.URL.http://www.rvb/pushkin/01 text/02 texst/01poems/0785.htm

7. Яган Мурат. Я пришел из-за гор Кавказа. URL.http://www. apsnyteka.org/92yagan_ya_prishel_iz-za_gor_kavkaza.html. C. 203

8. Ханаху Р.А. Малые культуры в условиях глобальных изменений в мире//Философия. Социология. Культурология. Майкоп.2006. №5. С.156.

Мусхаджиев C.-X. X.

\title{
Историческое сознание в социокультурном пространстве
}

\begin{abstract}
Аннотация: B статье рассматривается историческое сознание и историческая память в контексте истории Северного Кавказа. Историческое сознание - это очень сложное многогранное явление, которое включает в себя идеи, традиции, концепции, посредством которых индивиды, группы, общзности, этносы, нации формируют своё восприятие прошлых событий и вылдющихся личностей. Осмысление прошлого связывает триедино прошлое, настоящее и будущее, тем самым обеспечивая связь времён и поколений.
\end{abstract}

Ключевые слова: историческое сознание, историческая память, унификация, персонификация, глобализачия.

Наверное, я не ошибусь, если скажу, что научное творчество Руслана Асхадовича не ограничено национальными рамками. Возможно, в этом и преимущество адыгства. Руслан Асхадович - человек очень коммуникабельный, открытый. Он интересуется не только своей национальной философией, но и философией других народов, культур, религий, и это отрадно отметить. Тема моего сообщения «Историческое сознание и историческая память в контексте истории Северного Кавказа». Тема, конечно, очень масштабная, я тезисно основные понятия попытаюсь осветить. Историческое сознание - это очень сложное многогранное явление, которое включает в себя идеи, традиции, концепции, посредством которых индивиды, группы, 
общности, этносы, нации формируют своё восприятие прошлого, выдающихся событий прошлого, выдающихся личностей.

И осмысление прошлого связывает триедино прошлое, настоящее и будущее, тем самым обеспечивая связь времён и поколений. Историческое сознание тоже делится на три уровня. Первый, низший уровень - это те впечатления, индивидуальные переживания, которые личность испытывает в своей повседневной жизни. Второй уровень исторического сознания - это историческая память. Вот об исторической памяти и хотелось бы поговорить сегодня. Это неотъемлемая часть духовной жизни любого народа, которая формируется на основе не только исторических фактов, но и фольклора, эпоса, исторических преданий. Историческая память избирательна, то есть всегда выбирает те события, которые отражают сегодняшнее состояние сознания социума или той или иной группы. В этом плане, конечно, на Северном Кавказе больше апеллируют к трагическому прошлому - это Кавказская война, последствия вынужденного переселения значительной части адыгов, абхазов после Кавказской войны [1].

В другой части Северного Кавказа больший акцент делается на трагическое прошлое, связанное с депортацией советского периода. Это можно понять, потому что долгое время эти темы были табуированы.

Историческая память отличается персонификацией. Вот недавно были памятные события, связанные с очередной годовщиной завершения Кавказской войны, и просматривая в интернете материалы из разных мест: из Абхазии, из Нальчика, из Майкопа - я обратил внимание на то, что младшее поколение (школьники, студенты) держали в руках портреты с изображением известных исторических деятелей того периода. Это тоже, наверное, важно для того, чтобы возродить историческую память. И высшая ступень исторического сознания формируется под воздействием преимущественно средств массовой информации, телевидения, кино, литературы. Сейчас мы даже видим даже некий конфликт между различными уровнями исторического сознания, потому что нынешнее сознание ориентировано больше на средства массовой информации в связи с тем, что очень активна социальная сеть, нежели на фольклор. 
Ели раньше младшее поколение больше вечером слушало рассказы стариков, предания глубокой старины, то сейчас, к сожалению, им место уступает монитор компьютера. Таким образом, происходит определённая трансформация исторического сознания.

Хотелось бы завершить своё выступление словами известного учёного, который выдвинул теорию пассионарности, Льва Николаевича Гумилёва, сына выдающихся поэтов Николая Гумилёва и Анны Ахматовой. У Льва Гумилёва есть прекрасные слова, которые отражают историческую память: «Маятник столетий, как сердце, бъётся в сердце у меня, чужие жизни и чужие смерти живут в чужих словах чужого дня».

\section{Литература:}

1. Ханаху Р.А. Северный Кавказ в свете проблем глобализизации культуры//Кавказ и глобализация. 2008.Т.2. №2. С.110-120. 


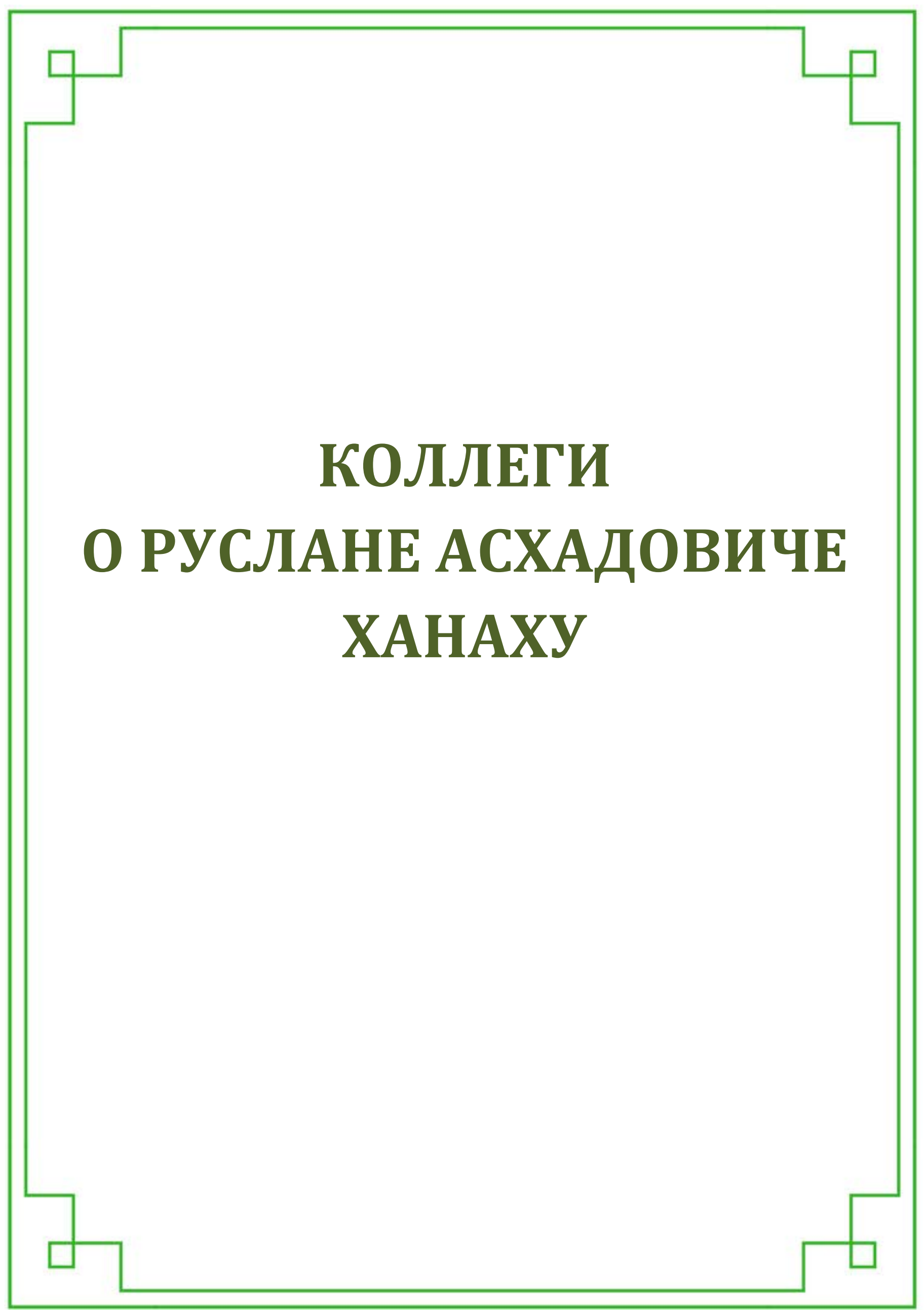




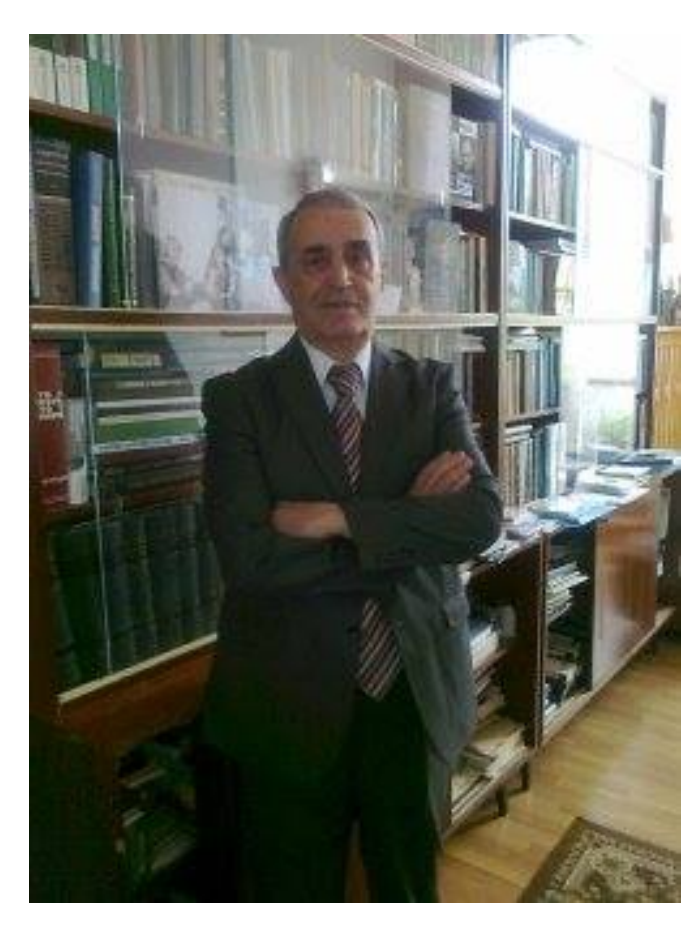

Делова Л. А.

Наука и судьба

Профессор Руслан Асхадович Ханаху известный в России и за её пределами филоософ и социолог, внесший существенный вклад в становление и развитие северокавказских философских и социологических исследований.

Р. А. Ханаху - основатель региональной школы социальных исследований. Он не только адаптировал внушительный интеллектуальный потенциал современных достижений философии и социологии к исследованию региональных проблем, но и предложил новый, свежий взгляд на северокавказский социум, выдвинув свою парадигму.

В содержательном плане она сводится к утверждению специфической культурной обусловленности отличий индивидуального и группового социального поведения представителей коренных северокавказских народов. В этом ключе он одним из первых стал разрабатывать проблемы “морально-этических кодексов” кавказских народов - «адыгагъэ» - (народной этики, включающей свод неписаных “правил” поведения), лежащих в основе их самоидентификации. Прикладные и теоретические исследования морально-этических кодексов северокавказских народов, духовности адыгов, осуществленные под руководством Р.А. Ханаху, получили широкое признание самых авторитетных учёных.

Под руководством Р.А. Ханаху реализовываются исследовательские проекты в других областях социальной науки: динамике ценностей в эпоху посткоммунистической трансформации; гендерным проблемам; философским аспектам мифологии, мировоззрения и религиозных верований адыгов; молодежным проблемам.

Он стал первым в Адыгее ученым, который возглавил относительно самостоятельный исследовательский коллектив (отдел философии и социологии 
республиканского института гуманитарных исследований), главными задачами которого являются региональные прикладные и теоретические исследования

Р.А. Ханаху родился 1 мая 1941 года в Адыгее. Детство и юность во многом повторили молодость людей его поколения: общеобразовательная школа, Советская Армия, ВУЗ.

После службы в армии Р.А. Ханаху поступает в Кабардино- Балкарский государственный университет на исторический факультет и вливается в относительно немногочисленные тогда ряды адыгов-обществоведов.

Успешно окончив университет, он работает по распределению в комсомольских и партийных органах. Затем - снова учеба. На этот раз в элитной аспирантуре Академии общественных наук при ЦК КПСС. Успешно защищает кандидатскую диссертацию по философии, посвященную вопросам теории социального управления.

Приобретенные знания нашли применение при руководстве им лекторской группой обкома партии, работе на кафедре философии Адыгейского государственного университета. Работа на этих должностях, помимо закрепления научнопрофессиональных навыков, способствовала приобретению и закреплению опыта работы с людьми, в том числе и с молодежью. В Адыгейском госуниверситете до сих пор помнят, насколько эффективно, нестандартно и интересно Р.А. Ханаху организовал студенческую систему самоуправления. Многие выпускники, в том числе и те, которые впоследствии сами защитили диссертации, бывшие коллеги по работе в органах государственной власти до сих пор поддерживают с Р.А. Ханаху деловые и дружеские отношения.

Постепенно для Р. А. Ханаху, как и для любого другого преданного науке человека, научно-исследовательская деятельность становится неотъемлемой частью жизни. С 1992 года - заведующий отделом философии и социологии Адыгейского республиканского института гуманитарных исследований.

В первые же дни работы нового для института и для всей республиканской системы науки и образования философско-социологического подразделения были составлены планы на краткосрочную и долгосрочную перспективы. Начался сбор, систематизация и обобщение разнообразных материалов по философским и социологическим проблемам этничности, кавказской этике и морали, актуальным ЭТНОФИАОСОФИЯ АДЫГОВ: ОТ МИФА К АОГОСУ : 
социальным проблемам современной жизни региона. В целях сбора первичной социальной информации был организован ряд полевых исследований, включая экспедиции за пределы Республики Адыгея.

В 1993 году возглавляемый Р.А. Ханаху научный коллектив выпустил монографию “Социальные проблемы молодежи”, в которой, пожалуй, впервые в республике молодежные процессы рассматриваются в научной парадигме.

С целью ознакомления общественности с научной работой отдела в 1994 году Р.А. Ханаху организовал выход в свет специализированного научно-информационного бюллетеня “Философия и социология”. Вокруг этого издания сплотилось много авторов, работающих не только в Адыгее, но и в других северокавказских республиках, а также в Краснодаре, Ставрополе, Ростове-на-Дону и Москве. В 1996 году отделом философии и социологии АРИГИ, возглавляемым Р. А. Ханаху, совместно с сотрудниками гуманитарного центра Российской Академии государственной службы при Президенте Российской Федерации был подготовлен сборник статей, объединенных общим заголовком “Наука, религия, гуманизм”.

Через год, в 1997 году, вышла в свет авторская монография Р.А. Ханаху 'Традиционная культура Северного Кавказа: вызовы времени

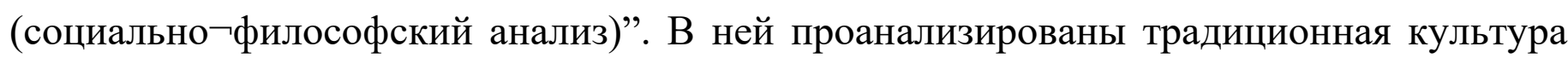
Северного Кавказа, теоретические и практические аспекты соотношения традиционности и современности, проблемы кавказской философско-культурной антропологии, межкультурного взаимодействия, социально-культурной конфликтности, культурной политики в условиях полиэтнических регионов, другие актуальные малоизученные проблемы.

Выход монографии в свет стал настоящим событием в научной жизни республики. Она получила большой резонанс и быстро стала библиографической редкостью. Монография «Традиционная культура Северного Кавказа: вызовы времени» вызывала и вызывает огромный интерес исследователей разных регионов страны и зарубежья. Свидетельством этого является огромное число ссылок на работу в научных изданиях. 
Ярким событием стал выход подготовленной учёным коллективной монографии «Мир культуры адыгов: проблемы эволюции и целостности», в которой опубликованы яркие исследовательские работы.

P. А. Ханаху - участник многих научных форумов. Так, он выступал на XXI Мировом философском Конгрессе в Турции (2003) и на многих других конференциях и конгрессах.

Работы учёного публикуют ведущие научные журналы страны. В 2014 году в журнале «Социологические исследования» РАН напечатана работа, выполненная совместно с О. М. Цветковым, о ситуации в мусульманской общине Адыгеи. Работа получила высокую оценку специалистов.

Научные достижения и организаторские способности Р.А. Ханаху признаны на уровне Адыгской (Черкесской) международной академии наук (АМАН), членом которой он избран, Академии информатизации, в конференциях которой он принимает постоянное участие и других. Его имя вошло в биобиблиографические сборники “Социологи России”, “Философы России” и другие издания.

Р.А. Ханаху является членом Российского философского общества, входит в диссертационный совет по социологическим наукам при Адыгейском государственном университете.

К своему юбилею профессор Р.А. Ханаху подошел, имея солидный исследовательский капитал, высокий научный и личный авторитет, большое количество учеников и единомышленников. Блестящее знание и понимание Кавказа, умение постичь его тайны и донести их до читателя, терпимость к людям, чужому мнению, готовность бескорыстно помочь снискали ему заслуженное уважение и любовь со стороны многих людей в самых разных уголках Кавказа и России.

Tов H.A.

\section{Планида Р. А. Ханаху}

1 мая 2016 года исполнилось 75 лет крупному ученому в области философии культуры и социологии, профессору, доктору философских наук, основателю региональной научной школы социальных исследований Ханаху Руслану Асхадовичу. Уроженец аула Тугургой, окончил исторический факультет Кабардино-Балкарского 
университета. После его судьба была тесно связана с Адыгейским обкомом комсомола, затем с Адыгейским обкомом партии вплоть до 1983 года. В этот период он оканчивает аспирантуру АОН при ЦК КПСС и начинает преподавать на кафедре философии Адыгейского педагогического института. Его увлечение исследованием философских и социологических аспектов традиционной культуры привело в Адыгейский республиканский институт гуманитарных исследований (АРИГИ), по существу единственный научно-исследовательский институт адыгского этноса. Здесь он подготовил и защитил докторскую диссертацию «Традиционная культура: специфика и проблемы эволюции» (1998).

Р.А. Ханаху - преданный науке человек, исследовательская деятельность стала неотъемлемой частью его жизни. Он организатор и бессменный руководитель отдела философии и социологии АРИГИ, который трудится в рамках разрабатываемого им научного направления. Важнейшими исследовательскими темами ученого являются философские и социологические аспекты кавказской этики и морали, феноменов массового сознания. Центральная проблема - теоретические основы традиционности и современности, присутствия в сегодняшней жизни «живой старины», которая и определяет полиморфичность современной культуры Северного Кавказа

Под руководством Р.А. Ханаху реализуются исследовательские проекты во многих областях социальной науки: динамике ценностей в эпоху посткоммунистической трансформации; гендерным проблемам; философским аспектам мифологии, мировоззрения и религиозных верований и др.

Ханаху Р.А. не только активный участник, но и организатор научных мероприятий, член Российского философского общества, входит в состав диссертационных советов. Под его научным руководством подготовлено более десятка кандидатов и докторов наук.

Особенность исследовательской работы Р.А. Ханаху - умение найти именно те проблемы, которые в тот или иной момент оказались центральными для развития всей области исследования проблем социологии и культурологии. Другая его особенность понимание вопросов методологии науки в широком философском и культурном контексте. Поэтому он обращается и к истории философии, и истории науки, и современной литературе по социологии и культурологии (одним из знатоков которой 
он является), и к современной логике, наконец, к теории и истории культуры. Он оказывает большую помощь государственным и общественным организациям в изучении и формировании общественного мнения, электоральных предпочтений населения и др.

Ученым Северного Кавказа известна научно-педагогическая деятельность Р.А. Ханаху. Он и руководимый им отдел часто выступают в качестве рецензентов по кандидатским и докторским диссертациям, защищаемым в диссертационных советах вузов Северного Кавказа.

Автор более двухста публикаций. Его труды востребованы специалистами в области философии и социологии, они часто ссылаются на них.

Мы трудимся вместе уже много лет, и хоть круг научных интересов у нас разнится, мы постоянно вместе участвуем в разнообразных обсуждениях. В нескольких случаях я принимала участие в этносоциологических исследованиях и в изучении языковой ситуации в республике. Работать с ним интересно и увлекательно.

Уже четверть века трудится в АРИГИ Р.А. Ханаху - один из интереснейших наших философов, человек яркого таланта. Он неиссякаемый источник новых идей, нетривиальных подходов. У него много учеников и поклонников. Замечательный семьянин, удивительный дедушка.

Я желаю ему здоровья, долгих лет жизни, больших философских свершений.

Гучетль 3. X.

\section{Адыгэ философ...}

Философием зэкІэ нэукэхэр зэрещэлІах. Сыд фэдэрэ Іофыгъуи екІолІэкІэ тэрэз къыфэбгъотыным пае философскэ екІолІакІэкІэ уекІолІэнэу ары зэраІощтыгъэр пэсэрэ филосэфхэм.

Ижъырэ лъэхъанэм къыщыублагъэу адыгэхэм джэныкъо философие зыфаІорэр яІагъ, сыд фэдэрэ зэмани, ар зэрэмыкІосэщтым тишІэныгъэлэжьхэр дэлэжьагъэх, ахэмэ ащыщ темыр Кавказым имызакъоу Урысыеми щызалъашІэу философие шІэныгъэхэмкІэ докторэу Хьанэхъу Руслъан. Руслъан ыцІэ энциклопедиехэу Урысыем ифилосэфхэр (IX-XX лІэшІэгъум) ыкІи Урысыем исоциологхэр зыфаІохэрэм адэхьагъ. 
УшІэныгъэлэжь къодыекІэ философиемрэ социологиемрэ ятарихъ ухэхьаныр псынкІэп, ар къэулэжьын фай, Хьанэхъу Руслъан ар къылэжьыгъ академичнагъэ хэлъэу адыгэ философием изэтегэуцон непэ къызынэсыгъэм мыпшъыжьэу дэлажьэ, ушэтынхэу, монографиехэу къыдигъэкІыгъэхэр нэучнэ дунаим икъу фэдизэу щылъэІэсых, щагъэфедэ. Адыгэ философием системэ гъэнэфагъэ хэлъэу зэтебгъэуцоным пае лъэпсэ чыжьэ къыщебгъэжьэн, методологическэ шІэныгъэхэмкІэ ууІэшыгъэн, лъэпкъ гупшысэри пшІэн фае. Шэныгъэлэжьым ахэр зэкІэ ІэкІэлъхэу философием дэлъэжьэнэу фежьэгъагъ.

Я 90-рэ илъэсхэм икъежьапІэхэм Руслъан АРИГИ-м Іоф щишІэнэу ыублэгъагъ, анахьэу зыфэщэгъэгъэ Іофыр лъэпкъ гумэкІыр арыти философскэ кІуачІэ иІэу, ар монографие ышІынышъ цІыфхэм зэралъигъэІэсыщтым ыуж ихьэгъагъ. Анахьэу ар къызщыригъэжьэгъагъэр пэсэрэ философием ІэкІэлъ амалхэр ары, ахэр ІэубытыпІэ ышІызэ мурад гъэнэфагъэ зыфигъэуцужьи, дунэе философием терминологиеу иІэхэр къызфигъэфедэхэзэ иІофшІэн лъигъэкІотагъ. А Іофым къылэжьыгъ монографиеу «Мир культуры адыгов» зыфиІоу 2002-рэ илъэсым къыдэкІыгъэр. Мы ІофшІагъэр адыгэ наукэм шІэныгъэ саугъэт фэхъугъ. Монографиер лъэныкъо пчъагъэмэ алъыІэсыгъ, (тарихъи, исскустви, фольклори, археологии, философии, социологии) адыгэхэм кІэнэу яІэм уасэ ритызэ, ащ «адыгагъэр» мэхьэнэ шъхьаІэу пхырыщыгъэу тхылъыр ыгъэпсыгъ. ЗэлъашІэрэ философэу илъэс пчъгъэрэ АКъУм ипроректэрыгъэу Виктор Макеевым мы монографием осэ ин ритзэ къеІо: «Адыгэмэ философие зэряІагъэр, нарт эпосыми къытеІо, нэмыкІ шІэныгъэ саугъэтхэми къытлъагъэІэсыжьыгъ, ау Хьанэхъу Руслъан иІофшІагъэу «Мир культуры адыгов» зыфиІорэм «адыгагъэм», «адыгэ хабхэм» философскэ купкІ шъыпкъэ зэряІэр дэгъоу ыгъэунэфыгъ».

Ащ фэдэу адыгагъэр научнэ лъапсэм тегъэпсыкІыгъэу зэгъэшІэгъэн гъогум уфеузэнкІы Руслъан имонографиеу «Традиционная культура Северного Кавказа: вызовы времени (социально-философский анализ)» зыфиІорэми. Адыгэ шэн-хабзэхэм философскэ идее гъэнэфагъэ хэгъэщагъэу тхылъыр гъэпсыгъэ. Морально-этическэ кодекс - зыфаІоу адыгэхэм яІэм шІэныгъэлэжьым зэкІэлъыкІокІэ гъэнэфагъэ хилъхьи социально-философскэ мэхьэнэ лъапсэ иІэу, игъэкІотыгъэу монографием къыщитыгъ.

Мы зигугъу къэтшІыгъэ нэучнэ ІэшІагъэхэр студенхэм, аспирантхэм, шІэныгъэлэжьхэм яІэубытыпІэшІоу щыт, сыда пІомэ, непэрэ мафэм цІыфхэр нахь ЭТНОФИАОСОФНЯ АДЫГОВ: ОТ МИФА К АОГОСУ : 
зыгъэгумэкІырэ Іофхэм авторыр алъэІэсы, ушэтынхэу ышІыгъэхэм къагъэлъагъогъэхэр зэрипхызэ зэфэхьысыжьыгъэхэр ІупкІэу къыреІотыкІых.

Философиемрэ социологиемрэ апылъ отделэу АРИГИ-м иІэм Хьанэхъу Руслъан ипащэу зылажьэрэр илъэс тІокІым къехъугъ, а уахътэм къыкІоцI отделым социологическэ ушэтын пчъагъэ ышІыгъ. Ахэм адыгеим иполитикэ Іофхэм язытет, бзэхэр зэрэзэрагъашІэрэм яІоф, къэхъурэ ныбжьыкІэхэм яшэн-зекІаукІэхэм зэхъокІыныгъэу фэхъухэрэр, хьакъулахьхэм ятын, дин зэфэшъхьафхэр зылэжьхэмрэм еплъыкІэ фыщытыкІэу афыряІэхэр, ІэкІыб къэралыгъохэм ащыпсэущтыгъэ адыгэхэу къэкІожьыгъэхэр, мыхэмэ анэмыкІыбэхэри. Мыщ лъыпыдзагъэу отделым, 20I4-рэ илъэсым «Динамика социально-демографической ситуации Республики Адыгея» ыІоу коллективнэ монографие къыдигъэкІыгъ. Отделым I997рэ илъэсым къыщыублагъэу 20I2-рэ илъэсым нэсэу социологическэ ушэтынхэу, упчІэжьэгъоу ышІыгъэхэр зэфэхьысыжьыгъэхэу тхылъым къыдэхьагъэх.

Ащ фэдэу хэкум щыхъурэ-щышІэрэ пстэуми отделыр ренэу ащыгъуаз, пІэлъэ пІуалъэу социологическэ ушэтынхэр, Іофыгъо зэфэшъхьафхэм афэгъэхьыгъэу ашІых, пэшІоргъэшІ еплъыкІэхэми алъэплъэх.

КъэІогъэн фае Хьанэхъу Руслъан ыпкъ къикІыкІэ Урысыем наукэхэмкІэ и Академие этнологиемрэ антропологиемкІэ и Институт - отделым Іоф дешІэ, тиреспубликэ Іофыгъо шъхьаІэу къыщыуцухэрэм афэгъэхьыгъэ социологическэ ущэтынхэр, упчІэжьэгъухэр научнэ льапсэм тетэу институтитІум зэдашЈы.

Джы дэдэм отделыр анахьэу зыдэлажьэрэмэ ащыщ адыгэ философскэ социологическэ гущыІалъэм изэхэгъэуцон. Мы гукъэкІыр зыер Хьанэхъу Руслъан ары, философскэ социологическэ терминхэр адыгабзэкІэ къэІуагъэу джыри адыгэ научнэ дунаим щыбгъэфедэн плъэкІынэу гущыІалъэ тиІэп. А проектым илъэбэкъухэр ригъэжьэгъэ къодый ныІэп, ау творческэ купэу Руслъан зэхищагъэм иІофшІэн лъегъэкІуатэ.

Ащ фэдэу Рулъан ригъэжьэрэ Іофым ыгуи ыпси хелъхьэ, ащ къыхэкІэу Іофэу ышІэрэмкІэ шІуагъи щытхъуи къелэжьы, иІэшІагъэхэри цІыф жъугъэхэм къашъхьапэ.

Хьанэхъу Руслъан Іоф дэзышІэрэ цІыфхэм мыхэр къыраІуалІэх:

Лаушэ Светлан - философие шІэныгъэхэмкІэ доктор, АКъУм иІофышІ. ШІэнгъэ творческэ гъогоу сызтетыр нахь ушъомбгъугъоу хъунымкІэ Хьанэхъу ЭТНОФИАОСОФИЯ АДЫГОВ: ОТ МИФА К АОГОСУ : 
Руслъан ишІогъэшхо къысэкІыгъ. Уахътэ къыхэкІыгъ Руслъан зипэщэ отделым сыготэу Іоф сшІэу. Отделым Іофыгъо горэ рихъухьанэу, е ушэтын горэ ышІынэу тытегущыІэнэу тызызэхахьэкІэ философ гупшысакІэр зыдиІыгъэу, Руслъан чыжьэу Іабэти методологическэ шІэныгъэхэр Іофым лъапсэ фишІыщтыгъ, а екІолъакІэр ары шІэныгъэлъэжьым иІэпІэІэсэныгъэ къэзыгъэлъагъорэр. Отделым Іоф щысшІэзэ диным фэгъэхьыгъэу игъэкІотыгъэ ушэтын гъэшІэгъон тшІыгъагъэ ащыгъум обществэм диным чІыпІэу щиубытырэр зэдгъэшІэныр тимурадыгъ. Ушэтыныр мэзэ пчъагъэрэ кІогъагъэ, ау а уахътэм упчІэжьэгъум (опрос) шъэфэу хэлъэхэр, ащ къыдэплъытэн фэе амалхэм тІэкІу тІэкІузэ Русльан къытфиІуатэщтыгъ, такъыфищэщтыгъ. Шэныгъэлэжьым иметод тытетэу упчІэжьэгъур кІуагъэ, Іофэу зэшІотхыгъэми шІуагъэ къытыгъ. Непэ къызнэсыгъэм Руслъан тигъэшІыгъэгъэ ушэтыным къыфэсэгъэзэжьы ІэубытыпІэ сэшІы ыкІи а уахътэр сищыІэныгъэ еджэпІэ гъэнэфагъэу хэхьагъ...

Жэнэ Заур - Оркъ-Хэбзэ ассоциацием ипащ - ЦІыфым ІэпэІэсэныгъэу хэлъыр къэмыущыфэкІэ, цІыфыр икъу фэдизэу псэурэп. АкъылышІохэм ары зыкІаІорэр «ІэпэІэсэныгъэр ары - цІыфыр цІыфы зышІырэр». ШІэныгъэр, шІэныгъэлэжьыныр, философиер, социологиер, ахэр гъэшІэгъоных, цІыфым иакъыл Іоф дашІэ, ау ахэр нахь гъэшІэгъон къэзышІыхэрэр Хьэнэхъу Руслъан фэдэ шІэныгъэлэжьхэр ары. Руслъан сыдигъуи шІэныгъакІэхэм алъэхъу. Ным къыдилъфыгъэу культурэ Хэбзэ гъэнэфагъэ зыдиІыгъэу, шынкІэу, самбырэу, щэІагъэ хэлъэу сыд фэдэрэ Іофи екІуалІэ, шІуагъэ хэлъэуи зэшІуехы. ШІэныгъэзехьэ шъыпкъэр сыдигъокІи тыгъэм фэдэу мэшІэты къыготхэми кІуачІэ ареты ишІэныгъэхэмкІэ халэлэу адэгуащэ - ащ фэд Хьэнэхъу Руслъан...

Гъыш Нухь - филологие шІэныгъэхэмкІэ доктор, Руслъан Іофэу ышІэрэм хэшІыкI фыриІэу, ащ гухахъо хигъуатэзэ мэлажьэ. Адыгэ философиеми социологиеми «адыгэ хабзэр» лъапсэ афишІызэ ахэр социологическэ ушэтынхэмкІэ ыгъэпытэжьзэ инэучнэ ІофшІагъэхэр егъэпсыгъэх. ЦІыфхэм, непэрэ мафэм ашІогъэшІэгъон темэхэр къеІэтых, ахэр зэхефых, научнэ шапхъэм илъэу, уахътакІэм диштэу, шъырытэу мэлажьэ. Руслъан, ежь фэдэ шІэныгъэлэжьхэу, философхэу, социологхэу, этнографхэу Къыблэ шъолъырым щыпсэухэрэм ямызакъоу Урысыем ишІэныгъэлэжь цІэрыІохэм Іоф адешІэ, къеуалІэх, дунэе научнэ форумхэми конгрессхэми ишъыпкъэу ахэлажьэ... 
Къуиекъо Амэрбый - экономикэ шІэныгъэхэмкІэ доктор, Хьэнэхъу Руслъан джыри партием и обком Іоф щишІэщтыгъ сэ сшІэ зэхъум. ИцІыф гъэпсыкІэкІи игупшысакІэкІи наукэм къызэрекІолІэщтыр ащыгъум къэпшІэнэу щытыгъ. ЩыІакІэм къышъхьэпэн ылъэкІыщт бэдзэр экономикэм ехьылІэгъэ идеехэр бэу иІэхэу, къызэриІорэм нэмыкІэу мэхьэнэ куу хэлъэу зэкІэлъыкІуакІэ гъэнэфагъэ хэлъэу тхыгъэу къыгъэлъагъощтыгъэх.

Я 90 - рэ ильэсхэм икъежьапІэхэм научнэ ушэтын фирмэу «Эксо»- къэлэ администрацием къыщызэІутхыгъагъ. Экономикэм фэгъэхьыгъэ Іофыгъохэр тыушэтызэ, шІогъэ къэкІуапІэхэм ямэхьанхэр дгъэунэфыштыгъэх. А лъэхъаным тихэку биржэм Іоф зэрэщишІэн ылъэкІыщтым иидеехэр къытфэущыгъэх. Тэ тикъэралыгъо биржэ зыфаІорэр щыІагъэп шъхьаем, илъэс шъитІукІи узэкІэІэбэжьмэ ІэкІыб къэралхэм биржэхэм Іоф ашІэщтыгъ. Бэдзэр экомикэр зытетым биржэ иІэн фай, ащ ыпкъы къикІэу пермскэ хьап-щып мурад биржэм ифилиал Мыекъуапэ къыщызэІутхи фирмэу «Эксом» етпхыгъ, лІыкІо еджапІэхэри зэхатщэхи, биржэм Іоф зэрэщыпшІэн фаем цІыфхэр фэтыузэнкІыгъэх. Іофэу тшІагъэм сэ сызэреплъырэмкІэ шІугъэ ин къытыгъагъ, апэрэ сатыу зэблэгъэкІынхэу тшІыгъагъэхэм Урысыем ятІонэрэ чІыпІэр щытыубытыгъагъ. Мы гукъэкІыжьым игугъу къызкІэсшІыгъэр, Руслъан иидеехэм Іоф адешІэ, ахэмэ научнэ лъапсэ яІэу, псэ къапигъэкІэн амал иІ, куоу мэгупшысэ...

Тэу Нуриетт - бзэшІэныгъэлэжь ГУАРИм ишІэныгъэ секретарь - Хьанахъу Русльан философиемкІэ докторыцІэ зэриІэр къэзыушыхьатырэ тхыль иІэми, философэу зильытэжьырэп. Арэу щытми ишІэныгъэ пкъыгъо зикІэсэ цІыф. Философием фэщэныгъэу фыриІэр ныбжьыкІэмэ алъегъэІэсы. Нэбгырабэмэ Руслъан мы шІэныгъэм къыфищагъэхэу алъытэ. Философие шІэныгъэм икупкI зэхэзышІэрэ цІыф, ежь ыгъэцакІэрэр къыкІимыгъэтхъэу, ау иІофшІэгъухэм, анахьэу зипэщэ купым, ІофшІэгъэ дэгъу зэшІуахыгъэу зыхъурэм ежьи лъэшэу щэгушІукІы, цІыфхэри щегъэгъуазэх, гушІуагъор адагощыным пае. ШІэныгъэлэжь зэхахьэ институтым зэхищэмэ ренэу камерэр иІэдэжь. Ежь пшъэрылъ зыфишЈыгъэу, къызыІухьагъэм щегъэжьагъ пІоми егъэлыягъэ мыхъунэу, институтым ихъишъэ етхы. Тихъарзынэщи къегъэбаи. 
«Философмэ яклубкІэ» зэджагъэхэу чэзыурэ зэхахьэхэрэм макІэу сахэсынэу хъугъэми, гу зылъыстагъэр - Руслъан дэІоныр нахь икІас. Зы упчІэ горэ къахилъхьанышъ, гупшысэхэу къыгъэущыгъэхэмэ ашъхьэ къырахы къэс нахьи нахь ыгукІэ зэригъатхъэрэр къыхэщэу шІэныгъэлэжьмэ ядэІу. ШІэныгъэ пкъыгъоу зыфэгъэзагъэр къыуигъаштэу зегъэпсы.

Руслъан етІани тыжъышІу! Ащ ипхъорэлъ цІыкІу зэу дэгъоу ыгъэсагъэшъ, зылъэгъурэм щымыгъупшэжьэу адыгэ кІэлэхъу хъупхъэу гум хапкІэ...

Шъхьэлэхъо Дарико, ГУАРИм иІофышІ, шІэныгъэлэжь. Наукэм ыгукІэ фэшъыпкъэу, непэ ышІагъэм ымыгъэразэу, нахь лъэгапІэм ренэу зыфэзыкъудыирэ кІуачІэ зыпкъырылъ, ушэтын ІофшІэныр зищыІэныгъэ щыщ шъыпкъэ хъугъэ цІыфхэм ащыщ Хьанэхъу Руслъанэ. Ар шъырытэу, гъэтІылъыгъэу, шІошъхъуныгъэ пыти фыриІэу, ыкІуачІи зыдишІэжьэу зиІофшІэн зыгъэцэкІэрэ цІыф, шІэныгъэ куу иІ, узыкІырыплъын, щысэ зытепхын шІэныгъэлІ.

Руслъанэ шІогъэшхоу сэ фэслъэгъурэр адыгэхэм якультурэ изэгъэшІэнкІэ зэхищэрэ ушэтынхэм наукэм иамалхэр ІэубытыпІэ къызыфишІыхэзэ къызэрякІуалІэрэр ары. Анахьэу къыхэбгъэщын фаеу сэлъытэ адыгагъэм имэхьэнэ купкI игъэунэфын, етІанэ шэн-зекІокІэ ухэсыгъэхэу адыгэхэр нэмыкІырэ цІыф лъэпкъхэм ахэзыушъхьафыкІыхэрэм алъапсэ икъыхэгъэщын, адыгэхэм ямифологие, ядунэегурыІуакІэ, ядин шІошъхъуныгъэхэм япхыгъэ Іофыгъоу зэшІуихыхэрэр ыкІи ащ афэгъэхьыгъэ тхылъхэу, статья зэфэшъхьафхэу къыхаригъэутыгъэхэр. ЫцІэ къесымыІон слъэкІыщтэп икъыдэгъэкІынкІэ пэщэныгъэ зыдызэрихьэгъэ тхылъэу «Мир культуры адыгов» зыфиІорэм. Тхылъыр зыфэгъэхьыгъэр адыгэ лъэпкъым игушъхьэлэжьыгъэ икъэухъумэн, илъыгъэкІотэн. Мыщ къыдэхьэгъэ статьяхэм кІочІэшхо ахэлъ, куух, гъэшІэгъоных. Ащ къыхэкІэу тиІофшІэнкІэ ІэубытыпІэшхо тфэхъух...

ШъхьаплІэкъо ГьучІыпс ГУАРИм иІофышІ, шІэныгъэлэжь. Узэрыгушхон шІэныгъэлэжьэу адыгэм иІэмэ Хьанэхъу Руслъан ащыщ, исэнахьат фэгъэхьыгъэ шІэныгъэ куу ІэкІэлъ, шІэныгъэ ушэтын ІэубытыпІэмэ афэкъолай, сэнаущыгъэкІэ ащ тхьэр къетагъ. ИІофшІэн гуетыныгъэшхо фыриІэу мэлажьэ, мурад гъэшІэгъонхэмкІэ иІофшІэгъухэр еумэхъых, ахэм язэшІохын зэкъотхэу дегъэлажьэх. ШІэныгъэшхо 
зыхэлъ мурадхэу Руслъан рихъухьэхэрэм, исэнахьатыгъо игупшысэгъухэр къегъотых къызхещэх...

Іоф дэпшІэщтымэ Руслъан фэдэ щыІэп цІыф гупсэфэу, самбырэу ори уимыгъэтхъытхъэу шІэныгъэу ІэкІэлъыр къыбдигощызэ уегъэпсэу, ар зымыуасэ щыІэп. ИмэфэкІэу мы мафэхэм хигъэунэфыкІырэм фэшІ тыгу къыддеІэу тыфэгушІо, псауныгъэ пытэрэ гъэшІэ кІыхьэрэ иІэнэу, иунагъо дэтхъэнэу, ишІэныгъэ псынэкІэчъ къызэтемыуцонэу тыфэлъаІо.

\section{Резцова И.Ю.}

\section{Я люблю его библиотеку...}

Руслан Ханаху - авторитетный ученый, один из лучших философов и социологов России.

У нас с Русланом Асхадовичем есть одна общая черта - любовь к книгам.

Я люблю его библиотеку, которую он скрупулезно собирает в течение всей жизни. Вторую такую уникальную сокровищницу знаний я видела на Ясной Поляне, в доме Льва Николаевича Толстого. Это не просто книги, это турне по миру и по временам.

Каждый раз, когда мне доводилось бывать в кабинете Руслана Асхадовича, мой взгляд автоматически направлялся туда, на его полки. Он мог меня спокойно оставить одну и выйти куда-то срочно в соседний кабинет, и эти минуты я тратила на то, чтобы глазами полюбоваться хотя бы на названия изданий. Представляете, сколько бы я получила удовольствия, если бы меня оставили на час с его книгами?

Руслан Асхадович - идеальный руководитель, мечта для любого исследователя, который стремится работать под началом интеллигентного, миролюбивого, умного и профессионального человека.

Много раз я ловила себя на мысли, что Руслан Асхадович открывает для тебя огромный черкесский мир. Он, этот мир, оказывается таким большим, что приходится браться за изучение дополнительных языков, потому что пласт работы предполагается слишком большим. 
Однажды, на круглом столе, посвященном его юбилею, профессор Алла Соколова призналась, что во время ее защиты докторской диссертации в СанктПетербурге намного больше вопросов задавали не ей, а Руслану Асхадовичу официальному оппоненту. И я даже не удивляюсь, почему так. С ним всегда интересно и комфортно.

Общаясь и работая с таким человеком, ты можешь себе простить некоторую человеческую слабость не устоять перед глыбой науки, наделенной глубокими человеческими качествами.

Именно поэтому мне хочется сегодня одного, чтобы Руслан Асхадович имел возможность и время реализовать все то, что он задумал из любви к адыгскому народу.

За его плечами фундаментальные труды, у него большой процент цитирования другими учеными в России и за рубежом (единицы могут похвастаться этим) и не менее большие планы на будущее. Об этих планах, вернее результатах этих планов, я уверена, общество скоро узнает. Пусть будет так! 


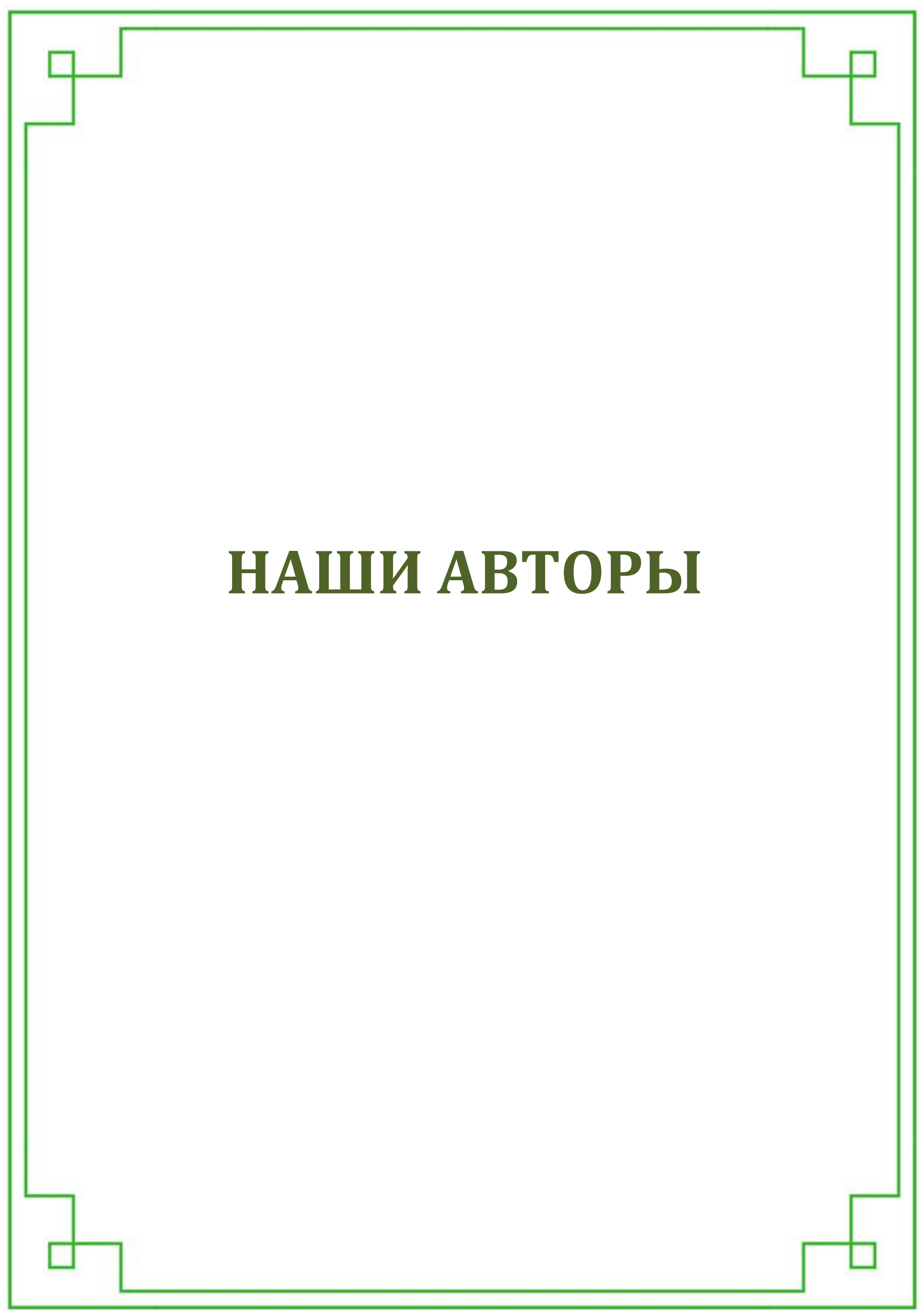


АЧМИЗ

Казбек Гучипсович

ГУБЖОКОВ

Марат Нурбиевич

ГУЧЕТЛЬ

Зухра Хачмафовна

ДЕЛОВА

Людмила Алиевна

ЖАДЕ

Зуриет Анзауровна

ЖAHE

Заур Киримизович

Калашаова

Дариет Аскербиевна

КУёК

Асфар Сагитович

МАМИЙ

Руслан Гилимович

МУСХАДЖИЕВ

Саид-Хасан

Хамзатович

НЕХАЙ

Вячеслав Нурбиевич

ПАРАНУК

Кутас Нуховна доктор исторических наук, главный научный сотрудник ГБУ РА «АРИГИ имени Т. М. Керашева».

кандидат исторических наук, ведущий научный сотрудник отдела этнологии и народного искусства ГБУ РА «АРИГИ им. Т.М. Керашева».

кандидат социологических наук, ведущий научный сотрудник отдела философии и социологии ГБУ РА «АРИГИ им. Т.М. Керашева».

кандидат социологических наук, ведущий научный сотрудник отдела философии и социологии ГБУ РА «АРИГИ им. Т.М. Керашева».

доктор политических наук, профессор, заведующая кафедрой теории, истории государства и права и политологии Адыгейского государственного университета.

кандидат химических наук, президент Ассоциации Кавказской Йоги Уорк Хабзэ.

кандидат социологических наук, доцент кафедры философии, социологии и педагогики факультета управления ФГБОУ ВПО «Майкопский государственный технологический университет».

кандидат филологических наук, ведущий научный сотрудник отдела фольклора ГБУ РА «АРИГИ им. Т.М. Керашева».

доктор филологических наук, профессор, главный научный сотрудник отдела литературы ГБУ РА «АРИГИ имени Т. М. Керашева».

кандидат исторических наук, доцент кафедры всобщей истории ФГБОУ ВПО « Майкопский государственный технологический университет», руководитель ценра народной дипломатии.

доктор социологических наук, доцент кафедры философии и социологии Адыгейского государственного университета.

доктор филологических наук, профессор кафедры литературы и журналистики Адыгейского государственного университета. 
РЕЗЦОВА

Ирина Юрьевна

СХАЛЯХО

Дарико Саферовна

TOB

Нуриетта Асланбиевна

ТУГОВ

Рамазан Галимович

ТХАГАПСОВА

Галина Григорьевна

ХУАКО

Заур Юсуфович

ХУАКО

Фатимет Нальбиевна

ЧУЯКОВА

Нафисет Муратовна

ШААВ

Асфар Аскерович

ШАДЖЕ

Асиет Юсуфовна журналист.

кандидат филологических наук, ведущий научный сотрудник отдела литературы ГБУ РА «АРИГИ им. Т.М. Керашева».

кандидат филологических наук, учёный секретарь ГБУ РА «АРИГИ имени Т. М. Керашева».

кандидат философских наук, главный научный сотрудник Национальной библиотеки Республики Адыгея; старший научный сотрудник отдела философии и социологии ГБУ РА «АРИГИ имени Т. М. Керашева».

кандидат исторических наук, ведущий научный сотрудник отдела этнологии ГБУ РА «АРИГИ имени Т. М. Керашева».

доктор исторических наук, профессор кафедры теории, истории государства и права и политологии Адыгейского государственного университета.

доктор филологических наук, профессор кафедры маркетинга, сервиса и туризма ФГБОУ ВПО «Майкопский государственный технологический университет».

доктор филологических наук, главный научный сотрудник отдела фольклора ГБУ РА «АРИГИ имени Т. М. Керашева».

доктор философских наук, доцент кафедры философии и социологии Адыгейского государственного университета. доктор философских наук, профессор кафедры философии и социологии Адыгейского государственного университета. 


\section{ТЕКСТОВОЕ ЭЛЕКТРОННОЕ ИЗДАНИЕ}

\section{НАУЧНОЕ ИЗДАНИЕ}

Научный редактор

Делова Л. A. - кандидат социологических наук.

\section{ЭТНОФИЛОСОФИЯ АДЫГОВ: ОТ МИФА К ЛОГОСУ}

Материалы круглого стола, посвящённого 75-летию доктора философских наук, профессора

Ханаху Руслана Асхадовича

(Майкоп, 24 мая 2016 г.) 